MARIA LETICIA DE OLIVEIRA REIS

Da experiência de perda à perda de experiência: um estudo sobre a Erfahrung na teoria psicanalítica, na filosofia e na clínica

(versão original)

São Paulo

2015 
MARIA LETICIA DE OLIVEIRA REIS

Da experiência de perda à perda de experiência: um estudo sobre a Erfahrung na teoria psicanalítica, na filosofia e na clínica

(versão original)

Tese apresentada ao Instituto de Psicologia da Universidade de São Paulo, como parte dos requisitos para a obtenção do grau de Doutor em Psicologia

Área de concentração: Psicologia Clínica

Orientador: Prof. Dr. Christian I. L. Dunker

São Paulo

2015 


\section{Da experiência de perda à perda de experiência: um estudo sobre a Erfahrung na teoria psicanalítica, na filosofia e na clínica}

Tese apresentada ao Instituto de Psicologia da Universidade de São Paulo para a obtenção do título de Doutor em Psicologia.

Aprovado em

\section{Banca examinadora}

Prof. Dr.:

Instituição Assinatura:

Prof. Dr.:

Instituição Assinatura:

Prof. Dr:

Instituição Assinatura:

Prof. Dr.:

Instituição Assinatura:

Prof. Dr.:

Instituição Assinatura: 
À Elisa, querida filha, que me perguntou se o seminário da Angústia é sobre vida de inseto.

Ao Leandro, pelo nosso encontro. 


\section{Agradecimentos}

Obrigada Christian Dunker, orientador que extrai o melhor de seus orientandos, pelo respeito e generosidade as quais sempre ultrapassaram os muros da universidade. Acompanhá-lo em seu percurso durante nossos anos de pesquisa tem sido gratificante e encorajador.

Obrigada ao grupo de orientação ao longo destes anos na Usp, desde a primeira composição com Abenon, Paulo Rona, Jonas, Rafael Lima, Marcelo Checchia, Leandro Santos, João Felipe, até à mais recente: Dani Sanches, Luciana Krissak, Clarice Paulon, Rafael Kossi, Dulce Coppedê, Jaque, Beto, Hugo, Ligia e Mayla. O momento especial das reuniões com a Karen, a saudosa Stella, a querida Cris Mathias e a nova amiga Mariana Moraes. Aquele grupo de agregados sempre acolhedor: Pedrinho Ambra, Paulo Beer, Paulo Sérgio, Ludu, Vivi, Natalie e Marcos Vinicius. Um obrigada especial à Anna Turriane: espero contemplar ao menos um pouco suas expectativas acerca da experiência.

Aos professores Nelson da Silva, Ines Loureiro, Ana Loffredo: que bom estar em sala de aula com vocês!

Um obrigada especial à Claudia Rocha, "Apanhadora no campo do centeio" dos alunos da pós!

Ao meu verdadeiro Clube da esquina: Ana, Bia, Chris, Conrado, Gui, Maris e Mi.

Às minhas amigas de infância e juventude: Fernanda e Marinella. À minha querida mãe, que entende minhas ausências e me apoia incondicionalmente e que me levava às bibliotecas quando pequena.

Ao pessoal gente fina de São Paulo: Mônica Nezan, Paula Pires, Ana Cristina Dunker, Luciana Lorens, Helô Ramirez, Tati Assadi, Bia Cruz, Bia Almeida, Gláucia e Glauci. Porta de entrada calorosa para mim nesta cidade.

À Fátima Milnitsky e à Gisela Haddad, amigas pra vida inteira, num encontro que começou nos anos dourados da Universidade São Marcos.

Um obrigada especial à Michele e à Rita. Construímos uma amizade tão piola!

E para mostrar que existe sim amor em SP: ao meu querido Leandro, que me reinventa a cada dia. Obrigada. E à Elisa, que aprendeu a ler durante meu doutorado, obrigada minha linda! Metade da sua vida você me viu estudando.

À Universidade São Paulo, pela pesquisa nos últimos anos e à Capes, pelo incentivo financeiro e amparo à minha pesquisa. 
E de tudo fica um pouco.

Oh abre os vidros de loção

e abafa

o insuportável mau cheiro da memória.

Carlos Drummond de Andrade 


\section{Resumo}

Trata-se de estudar a noção de experiência (Erfahrung) para compreender os relatos de análise e estudar os relatos para compreender a noção de experiência. Nossa tese sugere que a experiência em psicanálise apresenta-se sob o signo negativo, relacionado com o luto de um objeto perdido ou o inapreensível de um evento traumático, bem como pelo signo positivo de um acontecimento de elaboração ou reconstrução. Observamos como a noção de experiência se articula ao conceito de objeto, em sua característica de perda, como também em relação à experiência de um saber. A dificuldade de se dizer o que é uma experiência a coloca lado a lado com o conceito de Real, que traz em si o impedimento de que falemos direta e positivamente acerca dele. Este aspecto subjetivo e constitutivo da perda chamamos de experiências de perda, e o campo social da perda, os conflitos com a civilização, as ambiguidades com o outro, chamamos de perda da experiência. A perda da experiência do sujeito moderno produz um sujeito capaz do encontro com o novo, que a era moderna começou a oferecer. Ele não é nem tão forte que não possa ser transformado, nem tão fraco que não possa ser autêntico. É assim que tornamos a experiência um sucedâneo da transformação. Diante dessa via de mão dupla entre as experiências de perda (perda de si, perda de objeto) e a perda da experiência do sujeito moderno encontramos nossa hipótese de pesquisa: A noção de experiência em psicanálise se relaciona à perda de objeto e antes mesmo de haver a perda de experiência houve a experiência de perda. Compreendemos a escrita como mediadora entre estas duas experiências de perda. Esta parte da pesquisa nomeamos de experiência sensível. Percorremos os teóricos do pragmatismo, da filosofia crítica alemã e alguns pensadores estruturalistas franceses, considerados desde o ponto de vista da relação entre suas ideias e suas experiências pessoais de luto.

Palavras-chave: Experiência, perda, transformação, luto e real 


\begin{abstract}
The purpose is to study the notion of experience (Erfahrung) to understand the accounts of analysis and study them to understand the notion of experience. Our thesis suggests that experience in psychoanalysis is a negative sign, related to grief, to a lost object or to what is unintelligible in a traumatic event, but it also is as a positive sign of construction and reconstruction. The difficulty in defining what an experience is aligns it with the concept of what is Real, which places a barrier against our direct and positive statement about it. We call this subjective and constitutive aspect of loss experiences of loss, and we call the social scope of loss, the conflicts with civilization, the ambiguities with the other, loss of experience. The loss of experience of the modern subject creates a subject capable of meeting the other, something which the modern age began. The subject is not strong enough to become incapable of being transformed, or weak enough to become incapable of being real. This is how we make experience a substitute for transformation. In view of this two-way street between experiences of loss (loss of oneself, loss of the object), and the loss of experience of the modern subject, we came to our assumption of research: the notion of experience in psychoanalysis is related to the loss of the object, and before there even is the loss of experience there is the experience of loss. We understand writing as the mediator between these two configurations of loss. We called this part of the research related to writing sensitive experience. We studied the theorists of pragmatism, of the German critical philosophy and a few French structuralists, taken into account from the perspective of the relationship between their ideas and personal experiences of grief. At the end of the research, we extracted three accounts of analyses, which are related to what is real in experience, especially regarding the persistence in not writing.
\end{abstract}

Key-words: Experience, loss, transformation, grief, real 


\section{Sumário}

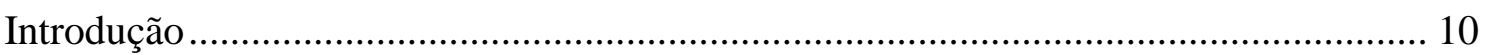

Capítulo 1. A noção de experiência em Freud e Lacan — os traços e as condições da experiência em psicanálise

Capítulo 2. Experiência sensível: escrita e experiências de perda

Capítulo 3. Da experiência de perda à perda da experiência

Capítulo 4. Sofrimento decorrente da perda de experiência: a solidão 94

Capítulo 5. Relatos: Falar de si lá onde não há mais si mesmo 103

Considerações finais

Referências Bibliográficas. 


\section{Introdução}

Em 2005 concluí o mestrado intitulado “A recordação da experiência analítica na infância: a narrativa do adulto". Após a leitura do pós-escrito de Freud (1922) à análise do pequeno Hans (1909), onde Freud torna público o esquecimento de Hans em relação à sua experiência analítica e até mesmo de sua fobia, me interessei vivamente pelo tema de lembranças de análise. Como foi possível que o pequeno Hans se esquecesse de seu tratamento? Através de entrevistas com adultos que passaram por uma experiência analítica na infância, visava a pesquisar as formas de lembrar a experiência. As recordações da infância se misturavam às recordações da experiência analítica e os relatos demonstravam como a maioria dizia não saber grande coisa. Descobri que em psicanálise, quando se trata de lembrança, trata-se também de esquecimento, formando uma tensão mediada pelo recalque — pois nem tudo esquecido está recalcado, mas o tudo que está recalcado está esquecido - ; que o trabalho da memória não é fazer sobreviver uma experiência, e sim permitir que ela seja esquecida para permanecer simbolicamente eficaz nesse esquecimento que a torna disponível para futuras lembranças.

Seja em Gmunden, a cidade onde o pequeno Hans contraiu a sua fobia, seja nas madeleines de Proust, foi demarcado e estabelecido um campo de pesquisa que concerne à memória, a relatos de análise e aos conceitos de narrativa e de experiência. As histórias de psicanálises com crianças me levaram aos relatos de experiências de análises. $\mathrm{O}$ interesse sobre os relatos nos levou a investigar a noção de experiência. Como organizar, transmitir, dar forma, sintetizar uma experiência tão longa e difícil como a experiência de análise? Por que foi preciso escrever sobre ela? Para quem ela é realmente destinada? E aqui estamos nós, dez anos depois, às voltas com essas perguntas.

A trajetória desta pesquisa percorreu livros de autores que passaram pela experiência de análise e resolveram escrever sobre ela, como Pierre Rey, George Perec e Sérgio de Campos, que serão apresentados e examinados posteriormente com mais vagar. Assim, de um lado colocamos a noção de experiência como um problema, uma questão a ser pesquisada; de outro, temos na literatura psicanalítica relatos de experiências. Desse modo, uma questão de método se colocou a partir de nossas 
inquietações. Vejamos como Freud em 1937 fez um exercício parecido, quando questionava o final do tratamento:

O outro significado de término de uma análise é muito mais ambicioso. Em nome dele se infere se foi promovida influência sobre o paciente até o ponto em que a continuação da análise não prometeria nenhuma ulterior alteração. Vale dizer, a pergunta é se mediante a análise se poderia alcançar um nível de normalidade psíquica absoluta a qual pudera atribuir-se além da capacidade para manter-se estável ... Primeiro examinaremos a experiência para ver se tal coisa ocorre e logo a teoria para saber se isso é, em geral, possível. (Freud, 1937/2004, p. 223)

A expressão alemã é inequívoca: "Erfahrung", ou seja, experiência. E é esta experiência que deve ser interrogada (Befragen), com vistas a estabelecer sua ocorrência ou acontecência (vorkommt), e só depois disso (und dann) a teoria, para verificar a sua possibilidade (möglich). ${ }^{1}$ Não há, em alemão, qualquer referência à ideia de que a teoria compreenderia um escopo "mais geral" do que o fato particular, em tese presumido pela experiência (Erfahrung).

O presente trabalho é uma investigação sobre o que significa interrogar a experiência, e como se pode fazê-lo no âmbito da experiência psicanalítica. É também parte de seu objetivo examinar as condições de transmissibilidade ou de "generalização", para retornar ao termo indevidamente introduzido pela tradução, dessa experiência, tendo em vista os relatos escritos de tratamentos psicanalíticos.

$\mathrm{Na}$ abertura do texto de Freud, tantas vezes repisado, sobre o término da análise reencontramos essa noção chave. A sua primeira frase diz: "A experiência nos ensinou que a terapia psicanalítica, ou seja, o liberar um ser humano de seus sintomas neuróticos, de suas inibições e anormalidade de caráter, é um trajeto longo." 2

Encontramos aqui novamente este termo estratégico, Erfahrung, que escolhemos traduzir por 'experiência'. É ele que ensina (lernen) sobre a terapia psicanalítica e sobre a libertação (Befreiung) que ela traz. É sobre ela que se estabelece um trabalho (Arbeit) longo.

\footnotetext{
1 "Man wird zuerst die Erfahrung befragen, ob dagleichen vorkommt, und dann die Theori, ob überhaupt möglich ist". (Freud, S. (1937) Die endliche und die unendliche Analyse. In Sigmund Freud Studienausgabe. Fischer, Frankfurt, 1975, página 361).

2 "Erfahrung hat uns gelernt, die psychoanalitishe Therapie, die Befreiung eines Mensches von seinen neurotischen Symptomen, Hemmungen und Charakterabnormitäten, ist eine langwierige Arbeit. (Idem, p. 357).
} 
Parece-nos que o objetivo de Freud nesse momento, no final de sua obra, era constatar os efeitos terapêuticos de uma experiência analítica: "Bem se entende que, quanto mais recente seja o êxito do tratamento, menos se prestará a nossas reflexões, pois não temos meio algum de prever o destino posterior de uma cura" (Freud, 1937/2004, p. 226).

Entretanto, reconhecer efeitos terapêuticos de um tratamento psicanalítico não é suficiente para organizar, transmitir, dar forma à experiência analítica. Seria empobrecedora a escrita da experiência baseada apenas em seus efeitos. Nosso método será estudar a noção de experiência para compreender os relatos e estudar os relatos para compreender a noção de experiência.

No nosso caso, com a construção de duas discursividades distintas a serem pesquisadas, temos, numa parte da pesquisa da experiência, uma ampla e extensa referência por se tratar de uma noção não especifica da psicanálise; e, em outra parte, os relatos daqueles que passaram por uma análise. Afinal, como pesquisar o sentido e as condições de entendimento da noção de experiência no escopo da experiência psicanalítica?

A noção de experiência está presente nos discursos psicanalíticos e psicológicos; assim, também nos ocupamos do modo como a experiência se localiza na filosofia e na cultura. Sua presença nesses discursos mostra como a noção não é bem definida e clara, o que a afasta que sua acepção seja tomada como um conceito. Vejamos algumas características do significante experiência: a experiência é "algo obscuramente alusivo e indefinível” (Shusterman, 1998, p. 48); "a meu ver, um dos conceitos menos elucidados que possuímos" (Gadamer, 1996, p. 369); “de todas as palavras no vocabulário filosófico é a mais difícil de manejar" (Oakeshott apud Jay, 2005, p.9).

O vocábulo 'experiência' contém o radical periri, encontrado também em periculum (perigo), cuja raiz indo-europeia per indica travessia, percurso e compõe, entre outras, a palavra peiratés, pirata.

A experiência parece ser uma palavra-valise, ou seja, parece caber em qualquer lugar e fazer desse lugar o seu uso e necessidade. Essa característica vulnerável do termo tem uma vantagem. Associada a outros termos, surge na leitura das obras de Freud e Lacan, assumindo o caráter de significante que faz com que o pesquisador tenha acesso ao movimento do pensamento dos autores. Além disso, o funcionamento da 
noção de experiência é intercambiável e oscilante e, na encruzilhada de suas indefinições, encontra sua utilidade e potência, ainda que tais características sejam desconcertantes numa pesquisa acadêmica.

Tomar a palavra experiência como um significante apresenta uma forma de pesquisa que se coordena com a forma como Lacan trabalhava os conceitos, oferecendo a eles o mesmo tratamento que aplica ao significante. No caso de experiência, a palavra abriga a complexidade que distingue a ciência da sabedoria, a generalidade de uma ocorrência social e a particularidade de um acontecimento individual, ponto fixo que alguém assume quando fala de si e a transformação que se verifica quando alguém fala de si. Nossa tese sugere que a experiência em psicanálise apresenta-se sob o signo negativo, relacionado com o luto, de um objeto perdido ou aquele que se refere ao inapreensível de um evento traumático, bem como pelo signo positivo de um acontecimento elaborativo, ou reconstrutivo.

Através do método de levantamento das incidências e aparições do significante 'experiência', percorremos as ocorrências da palavra em textos como a Interpretação dos Sonhos, Projeto..., Mal-estar na civilização, e na medida em que a discursividade da noção de experiência se articulava a um conceito, exploramos a relação entre eles. Desse modo, observamos como a noção de experiência se articula ao conceito de objeto, em sua característica de perda, como também em relação à experiência de um saber. Mostraremos, neste primeiro capítulo, como a experiência antecipa e compõe uma face do Real.

Um outro campo de leitura nos interessou, em continuidade à pesquisa da experiência, quando nos aproximamos da literatura que trata desse tema como Agamben em Infância e História (1978); W. Benjamin, em Experiência e pobreza (1933) e $O$ narrador (1936). Com esse cenário bibliográfico nos interrogamos acerca da crise do sujeito contemporâneo. Neste caso a psicanálise parecia fazer parte de uma longa tradição de reflexão sobre a modernidade. Tradição que a caracterizava pela perda da experiência. A experiência torna-se cada dia mais rara, como a citação que se segue demonstra: "O homem moderno volta para a casa a noitinha extenuado por uma mixórdia de eventos divertidos ou maçantes, banais ou insólitos, agradáveis ou atrozes entretanto nenhum deles se tornou experiência" (Agamben, 2005, p. 22). As leituras acerca da condição do sujeito moderno no mundo nos levaram à pesquisa da noção de perda da experiência, tal como trabalhada por Benjamin em Experiência e pobreza: 
Não, está claro que as ações da experiência estão em baixa, e isso numa geração que entre 1914 e 1918 viveu numa das mais terríveis experiências da história. Talvez isso não seja tão estranho quanto parece. Na época, já se podia notar que os combatentes tinham voltado silenciosos do campo de batalha. Mais pobres em experiências comunicáveis, e não mais ricos. Os livros de guerra que inundaram o mercado literário nos dez anos seguintes não continham experiências transmissíveis de boca em boca. Não, o fenômeno não é estranho. Porque nunca houve experiências mais radicalmente desmoralizadas que a experiência estratégica pela guerra de trincheiras, a experiência econômica pela inflação, a experiência do corpo pela fome, a experiência moral pelos governantes. (Benjamin, 1933/1996, p. 115, grifo nosso)

A noção de experiência que nos interessou diz respeito a uma perda, como a citação acima demonstra; e essa perda, da qual o sujeito moderno não mais escapou, concerne a uma transmissão, a um falar de si. O sujeito perde sua capacidade de narrar. Na citação anterior não somente importa o que se perde, mas como se perde. A forma como os combatentes voltavam silenciados impressionou a Benjamin porque se tratava de um momento de guerra, onde deveriam ter o que dizer: em vez disso, eles silenciaram. Aqui se abre um campo discursivo vastíssimo, pois foi exatamente nesse contexto de guerra que Freud escreveu importantes textos de sua obra, demonstrando, debatendo e enfrentando as dificuldades das perdas do sujeito e de suas próprias, ao longo da vida. Esse aspecto subjetivo e constitutivo da perda nós chamamos de experiências de perda; e o campo social da perda, os conflitos com a civilização, as ambiguidades com o outro, chamamos de perda da experiência.

Esse contexto de guerra sob o qual Freud vivia contribuiu sobremaneira na composição de uma teoria consistente em relação ao objeto, tal como em Luto $e$ melancolia, de 1915/1917. Talvez a perda do objeto seja o ponto de maior riqueza do texto freudiano, e isso se deve também à experiência do próprio Freud, escrevendo e trabalhando em zonas de conflito. Se a primeira tópica de Freud teve o primado da vida sobre a morte, nos anos 20 esse quadro teórico mudou completamente. Freud colocou em relevo a pulsão de morte, a tendência mais fundamental daquele que vive. "O fim de toda vida é a morte (Das Ziel alles Lebens ist der Tod)" (Freud, 1920/1982, p. 248).

Quais os efeitos subjetivos da perda da capacidade de comunicar experiências? A dificuldade da vida diária acaba por demarcar um modo de sofrer

(...) e aos olhos das pessoas, fatigadas com as complicações infinitas da vida diária e que veem o objetivo da vida apenas como o mais remoto ponto de fuga numa 
interminável perspectiva de meios, surge uma existência que se basta a si mesma, em cada episódio, do modo mais simples e mais cômodo. (Benjamin, 1933/1996, p. 119)

O sujeito, como demonstrado acima, deixa de pertencer a uma coletividade. Sua relação com o outro estará para sempre marcada por conflitos e dificuldades. Os diagnósticos sociais de Freud e Benjamin, portanto, apresentam convergências importantes para o estudo da crise do sujeito moderno.

Se não podemos abolir todo o sofrer, podemos abolir parte dele, e mitigar outra parte - uma experiência milenar nos convenceu disso. Temos outra atitude para com $a$ terceira fonte de sofrimento, a social. Esta não queremos admitir, não podendo compreender por que as instituições por nós mesmos criadas não trariam bem-estar e proteção para todos nós. Contudo, se lembrarmos como fracassamos nessa parte da prevenção do sofrimento, nasce a suspeita de que aí se esconderia um quê da natureza indomável, desta vez da nossa própria constituição psíquica. (Freud, 1930/2013, p. 30)

Bem, vemos como a noção da perda de experiência e o debate com a teoria de Freud é um trabalho para uma vida inteira de pesquisa. Norteados pela perda, nos questionamos acerca da possibilidade da recuperação da experiência, numa análise, o que corrobora nosso interesse específico pelos relatos literários e clínicos de quem passou por um tratamento psicanalítico. O tratamento do "homem psicológico contemporâneo", como definiu Zizek em 1985, (apud Koltai, 2000) passaria pela psicanálise a fim de transformar sua relação com o Outro, já que o sofrimento contemporâneo afasta o sujeito da autenticidade e da responsabilização engajadoras. A autenticidade e responsabilidade seriam traços, portanto, da verdadeira experiência? Aquisições duradouras depois de uma experiência analítica?

Não estávamos sós quando pensamos na possibilidade da recuperação, numa análise, da experiência perdida. A experiência analítica traria um tempo, um ritmo para o sujeito moderno, numa espécie de desaceleração da vida diária. Esta crença na recomposição da experiência no trabalho analítico estaria relacionada, segundo Kehl (2009), com a recuperação de um tempo para compreender:

São escassas as ocasiões que nos permitem outras formas de vivenciar os ritmos do corpo e os estados da mente que não os das sensações fugazes, das percepções e das decisões instantâneas. Em tais condições, sofre-se a falta do "tempo de compreender", a partir do qual o sujeito do desejo pode emergir como sujeito de um saber sobre si mesmo. (Kehl, 2009, p. 123, grifo nosso) 
Ora, voltamos a um ponto do qual necessitamos: o saber sobre si mesmo. Em que medida o sujeito perde a si mesmo na modernidade? A noção de experiência sofre as consequências quando o sujeito passa a ser moderno: “A psicanálise marca um ponto de inflexão na história das teorizações sobre a experiência. Afinal, a postulação freudiana do inconsciente coloca em questão o próprio sujeito da experiência tal como abordado, até então, pela tradição filosófica" (Loureiro, 2014, s/p.).

É precisa a referência de Rocha (2003) em relação ao posicionamento de Freud na história das razões:

(...) este filho da modernidade tornou-se um dos seus mais severos críticos, quando descentrou o sujeito de sua suposta autonomia autofundante e mostrou que a maior parte da vida psíquica é inconsciente, vale dizer, não é dominada pela razão, mas regida e dinamizada pela força das pulsões e das paixões (Rocha 2003) e que "o ego não é dono de sua própria casa" (Freud, 1917/1974, p. 178, grifo nosso)

Ainda que a temporalidade e o ritmo de uma experiência analítica se mostrem anacrônicos em relação ao ritmo acelerado do sujeito moderno, como observado por Kehl, a perda do sujeito moderno é irreversível. O sujeito moderno chega à teoria psicanalítica e recebe como débito a noção de inconsciente. Entendemos como débito a postulação freudiana de que as leis que regem o pensamento escapam à vontade do eu consciente, o que Lacan chamou de subversão do sujeito. Todo o tratamento possível já não é mais uma tentativa de recuperação da experiência, e sim uma elaboração, um tratamento do que foi perdido: "Face ao desamparo do sujeito na cultura, não existe cura possível, mas somente a perspectiva de construir um estilo subjetivo que seja capaz de lidar com os conflitos insuperáveis" (Birman, 1997, pp. 11-12, grifo nosso). Mas, será que somos mesmo tão pessimistas? Será que Freud deixou de acreditar na eficácia terapêutica do método analítico? O que os relatos de análise revelam em relação ao desamparo do sujeito? Trazer o debate da perda da experiência do sujeito moderno para pensar o mal-estar, o sofrimento e o sintoma é um dos objetivos laterais desta pesquisa, pois, em decorrência da perda de experiência, escutamos em nossos consultórios queixas como solidão, apatia, tédio, sentimento de inadequação e irrelevância sofrimentos que clinicamente são tomados como sintomas e que têm relação com o malestar social, diagnosticado por Freud e Benjamin. 
Entre as lembranças prazerosas e as desprazerosas, como opera a seletividade da memória? Em 1914 Freud escreveu o importante texto Recordar, repetir e elaborar, acerca do funcionamento das lembranças no psiquismo em relação esquecimento promovido pelo recalque e a repetição do sintoma. Opondo-se a esse funcionamento, Freud propõe a elaboração do trauma.

Desse modo, as experiências de guerra, amplamente discutidas por Freud em traumas e neuroses de guerra demonstraram que:

Tal necessidade de elaboração pode ser observada tanto nas modalidades individuais de retorno do sofrimento psíquico individual, quanto na repetição de fatos violentos e traumáticos que marcam as sociedades governadas com base na supressão da experiência histórica. Se a psicanálise freudiana fala em trauma individual, historiadores, cientistas sociais e alguns filósofos mencionam a possibilidade de traumas sociais. (Kehl, 2014, p. 109)

Diante dessa via de mão dupla entre as experiências de perda (perda de si, perda de objeto) e a perda da experiência do sujeito moderno, encontramos nossa hipótese de pesquisa: A noção de experiência em psicanálise se relaciona à perda de objeto, e, antes mesmo de haver a perda de experiência, houve a experiência de perda.

Precisamos deixar claro que partimos da clínica para pensar a experiência, por isso o interesse da demarcação teórica entre a perda de experiência e a experiência de perda. Esperamos, ao final dessa pesquisa, ter discutido algumas questões metodológicas importantes no que diz respeito à filosofia, à psicanálise e à clínica. Outra maneira de colocar a questão é afirmar que a experiência clínica é atravessada por uma racionalidade, por uma acepção de sujeito que nos cabe interrogar.

Alinhado aos críticos da perda de experiência está também Jacques Lacan. Assim como Freud, ele trabalhou com as elaborações possíveis acerca dessa perda. Vejamos como ele nomeia o sujeito moderno:

Não se trata de saber se falo de mim, de conformidade com aquilo que sou, mas se, quando falo de mim, sou idêntico àquele de quem falo. E não há aqui nenhum inconveniente em fazer intervir o termo 'pensamento'. Pois Freud designa por esse termo os elementos que estão em jogo no inconsciente, isto é, nos mecanismos significantes que acabo de reconhecer nele. Nem por isso deixa de ser verdade que o cogito filosófico está no cerne dessa miragem que torna o homem moderno tão seguro de ser ele mesmo em suas incertezas a seu próprio respeito, até através da desconfiança 
que há muito aprendeu a praticar quanto às armadilhas do amor-próprio. (Lacan, 1957, p. 521, grifo nosso)

O paradoxo nisso que grifamos na citação é bastante interessante aos nossos propósitos: a teoria de Lacan é avessa ao êxito das definições, o que não quer dizer que não se possa conceituar - dessa forma, essa atividade pode existir, ainda que fracassando. Esse aspecto é a pedra angular da noção de experiência. A dificuldade de se dizer o que é uma experiência a coloca lado a lado com o conceito de real, de evento, que traz em si o impedimento de que falemos direta e positivamente acerca dele. Há um desenvolvimento teórico em direção à negatividade. O conceito de real negativiza a estrutura das coisas e por todos os lugares onde o real tenta se fazer escrever. Esse caráter negativo estará posto, e isso afeta o saber sobre si mesmo; ou, melhor dizendo, não há mais si mesmo, como o homem moderno na citação anterior: seguro em suas incertezas a seu próprio respeito. A linha narrativa de nossa tese tem como força motriz a negatividade e a contradição que a palavra experiência expressa. Partimos das experiências de perda: do retorno daquilo que ontologicamente está na perda da experiência. Outra forma de sintetizar nosso percurso é afirmar que partimos da enunciação singular da perda (inconsciente) para tensioná-la no enunciado coletivo (social) da perda.

Uma vez situada a experiência de perda em relação ao sujeito moderno, podemos elaborar uma pergunta acerca deste: ele é mais vulnerável a perdas e aos lutos? Ainda que o sujeito contemporâneo esteja distante da narrativa, desembaraçado das tradições, desprendido de suas comunidades orgânicas, ele precisa se haver com imperativos de gozo, que tocam a restituição e retorno da experiência. A outra face desse processo parece ser a economia de ideais e ilusões que se forma em torno da negação da perda da experiência.

Se, antes do advento da noção de inconsciente, o lugar do sujeito pertencia a uma positividade, o percurso do sujeito moderno através da psicanálise de Freud à Lacan vai em direção a uma negatividade. Em relação aos discursos científico e filosófico, abre-se uma dificuldade para o leitor dentro desse campo. No que concerne ao texto lacaniano, Iannini $(2013$, p. 33) afirma: "Ao mesmo tempo que demarca a distância que separa a psicanálise em relação à filosofia, o vocabulário técnico empregado é oriundo principalmente da filosofia moderna." 
Como esta introdução vem demonstrando, a discursividade do campo da experiência percorre um longo caminho histórico, filosófico e literário. E nossa tese acaba por ser híbrida tal como as teses em ciências humanas costumam ser.

Uma parte de nossa pesquisa busca retirar de Walter Benjamin o centro de gravidade acerca da perda de experiência do sujeito moderno, mas entendemos que este é apenas um autor representativo de uma tradição interna e constitutiva ao comentário histórico sobre a modernidade.

Correspondeu a pensadores do século XX como Walter Benjamin, Martin Heidegger, Theodor Adorno, Georges Bataille, Michel Foucault e Roland Barthes a tarefa de resolver as implicações do ideal paradoxal do sujeito da experiência sem um sujeito em relação com a desdiferenciação (Entdifferenzierung) com as esferas de valor. Talvez a expressão filosófica mais importante dessa busca não apareceu, entretanto, na Europa do século XX, mas com um movimento impreciso que chegou a ser denominado pragmatismo. (Jay, 2009, p. 313)

Observamos que este movimento teórico produziu uma discursividade sobre a experiência que mantém, como em Freud e Lacan, uma gramática de falta, coincidentemente com a perda de si e entrada na linguagem para a teoria psicanalítica. $A$ tradição crítica alemã, o estruturalismo francês e o pragmatismo anglo-saxônico parecem produzir diagnósticos convergentes sobre o estatuto da experiência: fratura, perda, dissociação. A tentativa de uma reconstituição da experiência diz respeito ao que está perdido, um dos nomes do Real em psicanálise. Disso podemos inferir que $a$ realização subjetiva da perda da experiência concerne também a uma tentativa de modalização e de recomposição.

Situando o sujeito moderno, sem nos estendermos nesse aspecto, podemos dizer que nesse sujeito encontra-se o questionamento de que não habitamos o melhor dos mundos, como era colocado nos ditames de Deus. Não só sua ordem, sua finalidade ou seu projeto tornaram-se fonte crescente de suspeita, mas também a própria possibilidade de acesso "imediato" à experiência tornou-se um obstáculo incontornável. Há, além disso, um declínio da autoridade, que a psicanálise tematizou com a noção social de função social da imago paterna; há também um declínio social da função da experiência, quando se trata do mundo da técnica, do mundo funcional ou do mundo administrado. Estaríamos equivocados, entretanto, em deduzir que a espiritualidade desapareceu ou estaria ausente na história do saber. A racionalidade cresceu e, assim, o sujeito que 
surgiu é um sujeito que faz perguntas. Quem é o sujeito suposto ao saber? Uma vez que é na forma do saber que conseguimos dirimir o estatuto de transmissibilidade da experiência, seria preciso pensar qual sujeito se faz suposto ao saber quando este passa da oralidade presencial para a ausência inerente à escrita. O sujeito do saber agora é capaz do encontro com o novo, que a era moderna começou a oferecer. Ele não é nem tão forte que não possa ser transformado, nem tão fraco que não possa ser autêntico. É assim que tornamos a experiência um sucedâneo da transformação.

Uma das noções de experiência em nossa pesquisa advém desse aspecto transformativo. "Uma experiência, a partir de Benjamin, diz respeito a uma virada que implica um atravessamento de uma fronteira que demarca pelo menos dois espaços" (Leibson, 2004, p. 110, tradução nossa). É importante destacar que o caráter transformador da experiência surge como signo também de uma perda. Algo deixa de ser como era e passa a existir, modificado e alterado. Portanto, a perda é signo da transformação assim como a transformação é signo da experiência.

Foucault, numa entrevista a Ducio Trombatori, em 1978, afirmou: uma experiência é algo do qual saímos transformados. ${ }^{3}$ É interessante como o inefável e o impossível de demarcar aparecem na expressão: quelque chose. E aqui é preciso uma advertência importante, acerca das consequências de trazer um autor como Foucault em apenas uma entrevista. Se, por um lado, limitamos a interpretação do pensamento desse autor, por outro, seu testemunho nos abre a interrogações importantes no que concerne à experiência analítica e aos relatos. "Um pensamento como o de Foucault vive muito mais desses impasses e tensões, das zonas de atrito que ele cria, do que de suas possíveis soluções" (Chaves, 2014, p. 16). Dentro dessas zonas de conflito, se pudéssemos colocar a questão de uma forma simples, perguntaríamos: as pessoas mudam?

Esse aspecto de transformação imprime uma marca otimista em nossa tese. $\mathrm{Na}$ mesma entrevista a Trombadori, Foucault afirma: "Toda a minha pesquisa se baseia em um postulado de otimismo absoluto. Não realizo minhas análises para dizer: olha só como são as coisas, vocês caíram na armadilha. Só digo essas coisas na medida em que considero que isso permite transformá-las" (Foucault apud Allouch, 2014, p. 28).

\footnotetext{
3 "Une expérience est quelque chose dont on sort soi-même transformé" (Foucault, 1978, p. 860, grifo nosso).
} 
Quando declaramos nosso interesse em teóricos, críticos da perda de experiência como Benjamin, Adorno, mas também Barthes e Foucault, nos confrontamos, do outro lado, com o tipo de "otimismo metodológico" que seria necessário para exercer a clínica psicanalítica - na medida que esta implica, de modo inerente, um projeto de transformação, ainda que seja uma transformação sobre as ilusões de transformação.

(...) o recurso à rememoração de modos de vida pré-modernos não é nostálgico, como pensariam alguns de seus críticos. Não se trata de dizer, melancolicamente, "antes é que era bom", e sim de fazer lembrar que o mundo "já foi diferente" - portanto, ainda pode mudar. Daí decorre a aparente nostalgia sugerida em alguns textos de Walter Benjamin, como os mencionados acima. Se quiserem, podemos discutir ao final, o modo como este autor entende a modernidade, inspirado na poesia de Baudelaire, como um tempo que é sempre igual a si mesmo, portanto não apresenta nenhuma perspectiva de transformação no horizonte. Esta é a melancolia moderna: viver diante de uma eterna perspectiva de "mais do mesmo" - repetição que não produz diferença. "Que tudo fique como está, esta é a catástrofe", escreve ele num dos ensaios sobre a melancolia em Baudelaire. (Kehl, 2014, p. 115, grifo nosso)

Vemos assim como a ideia transformação regula o modo otimista ou pessimista de pesquisar. Vale lembrar como é recorrente em nossas clínicas o recurso utilizado pelos pacientes para se queixarem de seu sintoma atribuindo a queixa ao analista, dizendo: "não estou sentindo muita diferença, venho aqui há tanto tempo e em que mudei??" Este tipo de observação dos próprios pacientes é bastante importante clínica e teoricamente. Em certo sentido, isso equivale a perguntar pela margem de liberdade que pode ser alcançada pela experiência do tratamento. Isso imprime um valor clínico fundamental porque, muitas vezes, os próprios pacientes falam de sua experiência, fazendo relatos, memórias e juízos de seu trabalho analítico. Disso podemos inferir que aquele que escreveu sobre a sua experiência de análise, passou por essas questões, tem o que dizer, ainda que reconheça que sua transformação não é lá assim como se esperava no início do tratamento.

Retomando a entrevista de Trombadori, a experiência à qual Foucault se refere é a experiência de escrita de seus livros, da qual ele saía transformado. "Meus livros são minhas experiências, em um sentido que se entende o mais pleno possível". ${ }^{4}$ As leituras de Nietzsche, Bataille e Blanchot o influenciaram para que ele afirmasse que, por mais eruditos que fossem seus livros, havia neles algo que o arrancava de si mesmo. Temos,

\footnotetext{
4 "Mes livres sont pour moi des expériences, dans un sens que je voudrais le plus plein possible. (Foucault, 1978 , p. 860, 861).
} 
assim, uma incidência importante de mais um dos traços formadores da noção de experiência: a escrita.

(...) o fato de o sujeito reviver, rememorar, no sentido intuitivo da palavra, os acontecimentos formadores de sua existência, não é em si mesmo algo realmente importante. O que conta é que ele reconstruiu (...) Eu diria que, no final das contas, o que realmente se trata é menos de se lembrar do que de reescrever a história. (Lacan, 1954 , p. 23, trad. modificada)

Notemos como Lacan confere certa precedência da escrita (a reescrita) em relação à lembrança, mas também como na ideia de reescrita encontramos uma metáfora para a ação. Escrever ou reescrever sua própria história significa que, antes de tudo, ela foi apropriada, foi tornada própria; e, em segundo lugar, que ela permite novos atos, que ela faculta decisões futuras - que não apenas reescrevem o passado que já estaria escrito. Assim, como indicamos anteriormente, os relatos de análise estudados à luz da noção de experiência são trabalhados em torno da noção de real, mas também o conceito de real pode ser enriquecido quando discernido ou aproximado da noção de experiência. Se a noção de experiência diz respeito a uma gramática em torno do objeto, do objeto perdido, da experiência de perda e da perda de experiência, a nossa chave de leitura quanto aos relatos é a proximidade desses escritos e o conceito de real. Afinal, o valor dado em nossa tese acerca da perda decorre de que acreditamos que transformações subjetivas são proporcionadas pela irrupção do real, seja ele relacionado ao trauma, a uma perda ou a uma ausência.

Em nossa pesquisa, esse aspecto é discutido através da escrita relacionada às experiências de perda de Ralfh Waldo Emerson, Roland Barthes e Samuel Beckett. Cada um ao seu modo, ou ao seu estilo, escreveu sob o signo de um luto. Ralfh Waldo Emerson - o filósofo e poeta americano - perde seu filho de cinco anos em consequência da escarlatina; Barthes, depois da morte de sua mãe, escreve, inconsolável o Diário de luto; e Beckett escreve sobre a perda pungente de seu primeiro amor. Esse capítulo é de suma importância porque revela como a narrativa sofre os efeitos da experiência, ou seja, seria preciso saber quando e sob quais termos a narrativa adquire valor de elaboração, quando ela se submete a esta mutação de forma, do oral para o escrito. Esse aspecto é o que Kehl observa da experiência da coletividade dos filhos do pai primitivo da horda de Totem e tabu: 
Para dar consistência à manutenção do tabu do incesto instituído após o assassinato do pai primitivo, Freud imaginou que a coletividade dos filhos tenha sentido necessidade de restaurar o imaginário social, instituindo mitos e figuras totêmicas que sustentassem a força das interdições-tabu. Aqui, talvez, encontremos um ponto de comunicação entre o conceito freudiano de elaboração psíquica e o valor atribuído por Walter Benjamin às narrativas como forma, não apenas de inclusão de cada indivíduo na sua comunidade, como também de criação de sentido para a experiência histórica. $\mathrm{O}$ imaginário provê consistência ao campo simbólico, facilitando, com isso, sua transmissão e sua força de coesão social. (Kehl, 2014, p. 113)

Esse funcionamento de pensar a narrativa como elaboração é discutido, em nossa tese, em torno do valor da escrita de uma experiência, uma experiência que possa ser partilhada e reconhecida.

Temos aqui esse mito sobre a experiência de perda anterior à entrada na ordem simbólica. A morte do pai totêmico é o que nos autoriza a escrever a lei sobre a sua interdição. E a escrita sobre a sua interdição é, ao mesmo tempo, elaboração e repetição dessa perda. Vê-se, assim, que a forma da narrativa — ou, melhor dizendo, seu estilo — influi na transmissão da mesma. Ora, em relação às escritas de Emerson, Barthes e Beckett, não nos cabe dizer qual é melhor para transmitir a experiência, pois a pobreza da experiência, parafraseando Benjamin, é o terreno sob o qual se estabelecem todos os estilos. E a pobreza de experiência diz respeito à dificuldade de transmissão. A experiência está perdida, e narrar é um modo de se aproximar dela, de recriá-la ou de criar algo novo a partir do reconhecimento de sua perda. "O real é o limite de nossa experiência" (Lacan, 1957, p. 52); e, assim, toda fronteira, toda demarcação entre dois espaços, toda relação do sujeito com o outro, com os objetos, ao longo da vida, estará sempre afetada por essa dificuldade, por esse inefável da noção de experiência, postulando "a incoerência como condição da experiência” (Lacan, 1936/1998, p. 85). Podemos observar, em Lacan, o momento em que ele relaciona o real e o social na teoria freudiana:

O primeiro sinal dessa atitude de submissão ao real em Freud foi reconhecer que, dado a maioria dos fenômenos psíquicos no homem relacionar-se, aparentemente, com uma função de relação social, não há por que excluir a via que, por isso mesmo, abre-lhe o acesso mais comum: a saber, o testemunho do próprio sujeito desses fenômenos. (Lacan, 1936/1998, p. 84, grifo nosso) 
Ao final do trabalho, pretendemos ter demonstrado que, tanto na escrita das experiências de perda quanto nos relatos de análise, o que os autores pretendem é estabelecer uma demanda de reconhecimento, seja ela de seu sofrimento, seja de seu pertencimento a uma comunidade, a um grupo. Esse homem moderno, desembaraçado, que, quando escreve de si lá onde não há mais si mesmo, quando escreve sobre sua experiência, escreve justamente acerca do fracasso de escrevê-la. O real - o inominável, o irrepresentável — atravessa sua própria experiência a tal ponto que vem a fazer parte dela.

Ao final de sua obra, Lacan — em 1980, um ano antes de morrer —, em sua carta de "dissolução", afirma que: "A experiência analítica feita convida a uma contraexperiência que a compense" (Lacan, 1980/2003, p. 320). Aqui abrimos uma consideração acerca da noção de experiência que deve ser introduzida ao leitor. Trata-se da força da ação diante de uma experiência. Assim como o luto é uma espécie de paradigma da experiência de perda, dos processos de simbolização e recuperação da experiência, o trauma é um paradigma correlato em termos de perda da experiência. $O$ trauma é a experiência que não se faz, que não se realiza, que não se completa, e que, portanto, não pode ser perdida. O trauma é um acontecimento que tem a força de um ato. Pensar a narrativa social à luz da narrativa clínica convoca a utilidade e finalidade da experiência analítica. "Os limites éticos da psicanálise coincidem com os limites de sua práxis. Sua práxis não é senão prelúdio à ação moral como tal - a dita ação sendo aquela pela qual desembocamos no real" (Lacan, sem. 7, p. 32). Isso cabe um desenvolvimento importante próximo ao que Freud respondeu à sua paciente em 1895 nos Estudos sobre a histeria. A pergunta era: "De que modo o senhor pode ajudar-me, se, como o senhor próprio diz, é provável que meu sofrimento esteja relacionado às condições e vicissitudes de minha vida"? E Freud responde:

Não duvido de que, para o Destino, deveria ser mais fácil do que para mim (remediar seu sofrimento); mas a senhora convencer-se-á de que muito se terá aproveitado se conseguirmos mudar sua miséria histérica em uma infelicidade comum. Contra esta última, poderá melhor a senhora se defender com uma vida psíquica restabelecida. (Freud, 1895/2004, grifo nosso)

Essa passagem de Freud nos aproxima do aforisma lacaniano: passar da impotência à impossibilidade. Mas, como desenvolvemos no capítulo da filosofia, o inominável e o imprevisto são formas de incidência e tratamento do real — pois, diante 
do acaso, onde o sujeito não tem o que fazer, ele pode ainda decidir como reagir ao acontecido.

As narrativas de sofrimento na clínica, nesse sentido, devem possibilitar - ao sujeito que sofre - não apenas viver novamente a experiência irrealizada ou não simbolizada, mas facultar algum tipo de ação que altere esse estado de coisas. Se o real é o limite da experiência, o destino da psicanálise é o real. Nossa tese tem como ponto de partida o objeto e como ponto de chegada, o real. "Da impotência à impossibilidade", como observou Lacan, mas com a potência de criação que o acaso oferece.

No recurso que preservamos do sujeito, a psicanálise pode acompanhar o paciente até o limite extático do 'Tu és isto' em que se revela, para ele, a cifra de seu destino mortal, mas não está só em nosso poder de praticantes levá-lo a esse momento em que começa a verdadeira viagem" (Lacan, 1949/1998, p. 103, grifo nosso)

Mostraremos como a noção de experiência é um sucedâneo da essência do tratamento psicanalítico; como a experiência antecipa e compõe uma face do Real; $e$, ainda, como a experiência em direção ao real é o objetivo ou o fim do tratamento. Afinal, o que seria levar o sujeito ao momento em que ele começa a sua verdadeira viagem, senão à fronteira com o real?

No primeiro capítulo levantamos os traços e condições da noção de experiência em psicanálise. Fazemos uma pesquisa sobre a incidência da palavra experiência em textos de Freud e Lacan, observando o movimento da noção de experiência ocupar uma relação com o objeto perdido. Um dos pontos importantes desse capítulo é mostrar como a ação e o perigo são os componentes do que Freud chamou de etiologia mista da neurose. A relação com a perda do objeto rege a vida com os outros, onde o sujeito sempre estará às voltas com uma forma de ausência. Mostramos também como o conceito de objeto $a$ é a forma lacaniana de designar as experiências de perda.

No segundo capítulo investigamos a importância da escrita para a noção de experiência. Há, na escrita, uma espécie de terceiro modelo - além do luto e do trauma - sobre a possibilidade de elaboração e de aproximação do real da perda da experiência e da experiência real de perda. A escrita, mas também a experiência sensível, parecem ser condições que produzem uma espécie de mediação entre as experiências de perda e a perda de experiência. Chamamos de experiências de perda as 
experiências em que o sujeito se relaciona ao objeto perdido, imprimindo a característica de falta no sujeito dividido. Chamamos de perda de experiência, o modo como o social imprime a falta no sujeito.

No terceiro capítulo nos aprofundamos no luto como modelo para a experiência de perda. A demonstração da tese de que há uma espécie de dialética entre a experiência de perda e a perda de experiência nos levará aos teóricos do pragmatismo, da filosofia crítica alemã e a alguns pensadores estruturalistas franceses, mas considerados desde o ponto de vista da relação entre suas ideias e suas experiências pessoais de luto. A nossa chave de leitura da perda de experiência descobre, dentro das filiações teóricas, que há nomeações distintas na filosofia para a noção de experiência, tais como Experiência interior e Experiência pura.

Nosso quarto e breve capítulo é uma espécie de exemplificação de nossa tese à luz de uma experiência social ascendente, a saber, a solidão. Sendo tematizada tanto pelos teóricos sociais que se dedicaram às patologias da individualização quanto pelos próprios analisantes, a solidão constitui-se em uma espécie de paradigma convergente do sofrimento do sujeito moderno tal como surgem em nossos consultórios. A solidão presta-se, assim, a representar perfeitamente a inversão dialética entre a experiência da perda e a perda da experiência, problema que ocupa esta tese.

No quinto e último capítulo, chegamos ao nosso destino abordando os relatos de análises. Detivemo-nos em três escritas de experiências distintas sobre o tratamento psicanalítico: a de um psicanalista (Sergio de Campos) às voltas com a validação de sua experiência no contexto institucional do passe; a de um jornalista (Pierre Rey) interessado no retrato de um personagem; e, por fim, a de um escritor (Georges Perec) às voltas com pretensões literárias. Escolhemos esses três relatos pela diferença temporal e cultural que se verifica entre eles, o que nos permite ver com mais clareza certos aspectos regulares, bem como tratamentos distintos desse mesmo problema que é a transmissão da experiência. Delas extraímos o que se relaciona ao real da experiência, principalmente no que diz respeito ao que não cessa de não se escrever. Valorizamos os três relatos de modo que a forma da escrita da experiência seja mais importante que o juízo sobre ela. 
Poderíamos sintetizar nossos objetivos da seguinte maneira:

1- Apresentar uma noção psicanalítica de experiência (Erfahrung) envolvendo índices como ação e simbolização, modos de linguagem como a narrativa e a escrita, no quadro de dois modelos, representados pelo luto e pelo trauma, em Freud, e pelo conceito de Real, em Lacan;

2- Mostrar como a perda da experiência, tal como foi pensada pelos teóricos críticos da modernidade, encontra sua dialética com a experiência de perda, tal como foi tematizada pela psicanálise de Freud e Lacan. No interior dessa dialética se pode compreender a importância dos processos transformativos imanentes a uma possível definição psicanalítica de experiência;

3- Mostrar como a escrita de tratamentos psicanalíticos efetuada por analisantes contém os traços e a dialética presentes no que chamamos de experiência em psicanálise. 


\section{Capítulo 1. A noção de experiência em Freud e Lacan — os traços e as condições da experiência em psicanálise}

O presente capítulo procura fazer uma cartografia da noção de experiência em Freud e Lacan; discutir a ocorrência do termo nos dois autores; mapear e evidenciar a noção, bem como mostrar os usos distintos ou comuns do termo entre um e outro.

A interpretação dos sonhos foi o texto escolhido para a nossa primeira busca da noção de experiência, por ser um importante documento clínico onde Freud faz um incansável exercício de descrever, nomear e interpretar sonhos — os seus próprios sonhos. Suas associações não foram colocadas de forma evidente, mas a narrativa elaborada toma um caráter tão preciso e envolvente que o leitor vai se dando conta de que aquelas associações tão vivas só poderiam ser, mesmo, do próprio sonhador. Assim, tem a força da experiência do autor, que completa a atividade de experimentar ao narrar e teorizar seus sonhos, trazendo como consequência a transmissão dos mesmos como essenciais na teorização do inconsciente. Desse modo, podemos tirar disso um possível princípio de método: para reconstruir a experiência do sonho, Freud se baseia em si mesmo. Ao longo desse texto, Freud cita os autores que investigaram os sonhos antes dele, apontando as diferenças e semelhanças entre esses autores e as suas próprias formulações Nessa diferenciação Freud reconhece que a interpretação dos sonhos depende exclusivamente do sonhador e chega a um postulado ou a um entendimento generalizável em relação aos sonhos: o sonho é a realização de um desejo. É paradoxal o trabalho onírico, pois ora envolvem experiências de satisfação para o sonhador, ora envolvem experiências de desprazer, causando incertezas, retorno de lembranças esquecidas - como em sonhos de morte de familiares e pessoas queridas. Mas é no trabalho de associação que os dados laterais das lembranças acabam por revelar que tais sonhos trazem uma satisfação substituta, incompleta, inconsciente. É nesse cenário que apresentaremos como a noção de experiência aparece no texto, destacando, de saída, o caráter singular de serem os sonhos, experimentados pelo próprio Freud, o material de sua investigação. Portanto, a base da teoria da psicanálise está na trajetória da análise de um homem e de seus sonhos, calcada, portanto, na experiência onírica de seu autor. 


\subsection{A experiência em $A$ interpretação dos sonhos}

A primeira vez que a noção de experiência surge no texto $A$ interpretação dos Sonhos diz respeito à relação entre vida onírica e vida de vigília:

Por mais extraordinário que seja aquilo que faça com esse material, o sonho jamais pode se separar verdadeiramente do mundo real, e tanto as suas criações mais sublimes quanto as mais burlescas precisam sempre emprestar sua matéria prima daquilo que passou diante de nossos olhos no mundo sensível, ou que, de algum modo, encontrou lugar no curso de nossos pensamentos de vigília; em outras palavras, daquilo que já experimentamos exterior ou interiormente. (Freud, [1899]1900/ 2012, p. 24, grifo nosso)

Nesse contexto Freud ressalta a relação do sonho com o mundo real, mas também o valor daquilo que é experimentado, compondo um trabalho da memória no psiquismo.

Devemos, pelo menos, considerar conhecimento incontestável que todo o material que compõe o conteúdo onírico provém de alguma forma da experiência $\mathrm{e}$, portanto, que é reproduzido, ou lembrado, no sonho. Seria um erro, contudo, supor que essa ligação se produza sem esforço, como resultado evidente de uma comparação. Ao contrário, essa ligação precisa ser buscada atentamente e, em muitos casos, sabe se ocultar por longo tempo. (Freud, [1899]1900/ 2012, p. 25, grifo nosso)

Ficam claros os trabalhos em questão: não há ligação sem esforço, ao contrário, ela deve ser buscada através do trabalho da memória. O esforço, dessa forma, é parte da experiência e de seu conteúdo. Vemos como a experiência do sonhador é relevante para a composição do material onírico, que implica um trabalho do psiquismo, que Freud denominará experiência onírica, que é aquela em que se operam as atividades do sonhador, coletando as experiências da vigília e fazendo suas complexas articulações na atividade de sonhar. O que chamamos de complexas articulações Freud desenvolverá melhor nos capítulos VI e VII, em que associa conceitos fundamentais, como o trabalho de condensação e deslocamento, com a ação de lembrar e esquecer, mediados pela relação com o conflito. Na carta de 2/5/1897 temos, como exemplo de conflito, o acesso às cenas sexuais primitivas: "As fantasias provêm de coisas que foram ouvidas, mas só posteriormente entendidas, e todo o material delas, é claro, é verdadeiro. São estruturas 
protetoras, sublimações dos fatos, embelezamentos deles e, ao mesmo tempo, servem para alívio pessoal" (Freud, 1897/2001).

Freud nos adverte adiante que, mesmo que o sonho se baseie em experiências de vigília, essas não são essencialmente experiências de vigília recentes, e que o processo de elaboração dos sonhos, o trabalho dos sonhos, tem predileção pelo indiferente e pelo que pode não ter sido percebido pelas experiências diurnas. Freud então desenvolve a ideia, a partir de outro autor chamado Strumpell, de que, no sonho, com algumas exceções, não ocorre repetição de experiências; há normalmente uma alteração entre o experimentado e o sonho, e, quando isso ocorre, Freud denominou "retorno onírico" quando no sonho está colocada com exatidão a experiência diurna, onde pouco é modificado ou substituído. Na sessão D, intitulada "Por que esquecemos o sonho após o despertar", Freud ([1989]1900/2012, p. 61) afirma que a maioria das imagens oníricas são experiências únicas. Nesse mesmo tópico, apresenta a experiência de outra forma, como "experiências da psique reais e verdadeiras":

Os elementos oníricos não são de forma algumas meras representações, mas experiências da psique reais e verdadeiras, tais como surgem na vigília pela mediação dos sentidos. Enquanto na vigília a psique representa e pensa por imagens verbais e pela linguagem, no sonho ela representa e pensa por imagens sensoriais reais. (Freud, [1989]1900/2012, p. 68)

As várias nomeações de experiência que observamos acerca dos sonhos implicam três momentos diferentes: as experiências diurnas prévias; a do próprio momento do sonho (experiência onírica) e a experiência de realização de um futuro possível desejo. Disso, podemos inferir a seguinte pergunta: trata-se de uma só experiência ou três experiências distintas?

Logo após ressaltar a dignidade de um processo psíquico, Freud faz um enunciado de bastante importância para a pesquisa do termo 'experiência', ele cita uma formulação de Robert (1886), outro pesquisador dos sonhos que Freud estudou, de que a atividade de sonhar, a experiência onírica, é uma experiência curativa: "Os sonhos têm força curativa, aliviante" (Freud, [1899]1900/2012, p. 99).

Quando Freud apresenta a análise de alguns sonhos, ele fala em experiências importantes e experiências causadoras, aquelas que influenciam o trabalho onírico pela força de seu acontecimento - essa impressão diurna é a fonte onírica, é a experiência 
causadora do dia anterior. Freud destaca que a experiência importante pode ser aquela de conteúdo irrisório:

No conteúdo onírico encontro apenas uma alusão à impressão indiferente, e assim posso confirmar que o sonho prefere incorporar coisas secundárias da vida em seu conteúdo. Na interpretação, ao contrário, tudo conduz à experiência importante que com razão provocou o sonho. Se eu julgar o sentido do sonho, como cabe fazê-lo, segundo o conteúdo latente trazido à luz pela análise, chego de maneira inesperada a uma nova e importante descoberta. Vejo que se desfaz o enigma representado pelo fato de o sonho se ocupar apenas dos fragmentos insignificantes da vida diurna; também preciso contradizer a afirmação de que a vida psíquica da vigília não prossegue no sonho, e que ele, em compensação, desperdiça atividade psíquica com material irrisório. O contrário é verdadeiro; o que nos ocupou durante o dia também domina os pensamentos oníricos, e só nos damos ao trabalho de sonhar com aqueles assuntos que durante o dia nos deram o que pensar. (Freud, [1899]1900/2012, p. 195; grifo nosso)

Assim, observamos um novo quantitativo da experiência: sua importância e sua continuidade. E, mais adiante, admite: "Ainda nos deve parecer questionável e estranho o processo psíquico por meio do qual, segundo nossa exposição, a experiência indiferente se torna substituta da experiência psiquicamente valiosa" (Freud, [1899]1900/2012, p. 197). Os processos de substituição de valor ou importância ocorrem em nome da mais geral exigência de continuidade — temporal, de forma ou de conteúdo.

Vale destacar, no entanto, que, assim como a característica do irrisório das experiências importantes, a memória também funciona com suas lembranças aparentemente secundárias. Freud desenvolveu essa teoria em Lembranças encobridoras (1899), texto onde fica claro como o princípio da continuidade da experiência pode valer-se da substituição de lembranças importantes por lembranças secundárias laterais.

Freud explica o funcionamento da recorrência dessas experiências pelo processo de deslocamento: "é como se ocorresse um deslocamento da ênfase psíquica" (Freud, [1899]1900/2012, p. 197). Dando exemplos de deslocamentos na cultura - como o da virgem que ficou só e se dedica aos animais; o de Otelo, que teve uma crise de fúria por um lenço perdido; o do solteirão que se torna um colecionador apaixonado —, Freud demonstra o funcionamento psíquico através de experiências que aparentemente 
demonstram uma coisa, mas que, na realidade, significam outra. Freud conclui sobre esse funcionamento:

Assim, interpretamos o fato de o conteúdo onírico acolher restos de experiências secundárias como uma expressão da distorção onírica (por deslocamento) e lembramos ter reconhecido nessa distorção uma consequência da censura que controla o trânsito entre duas instâncias psíquicas. (Freud, [1899]1900/2012, p. 198, grifo nosso)

Desse modo chegamos a outra possibilidade: há instâncias psíquicas que operam descontinuidades da experiência, como a censura. Nossa pesquisa da ocorrência da noção de experiência em A interpretação dos sonhos no permite indicar os qualitativos preliminares da noção de experiência em Freud. Ela é uma unidade (continuidade) no tempo que trabalha com intensidades na relação de perigo/prazer com o outro.

Textualmente, experiências infantis aparecem pela primeira vez em $A$ interpretação dos sonhos na parte $\mathrm{V}$, "O material e as fontes do sonho", na sessão A: "O recente e o indiferente no sonho".

Quando algo no sonho tem o caráter de uma fala, ou seja, quando é dito ou ouvido, não apenas pensado - o que se pode distinguir com segurança na maioria dos casos -, provém de falas da vida de vigília, que, no entanto, foram tratadas como matéria-prima, desmembradas, ligeiramente modificadas, mas sobretudo arrancadas de seu contexto. No trabalho de interpretação, podemos partir dessas falas. Assim, donde provém a fala do açougueiro, “isso não está mais disponível?” De mim próprio; alguns dias antes eu tinha lhe explicado que "as experiências infantis mais antigas não estão mais disponíveis como tais, mas são substituídas na análise por 'transferências`e sonhos". (Freud, [1899]1900/2012, p. 204/205)

Vemos como a experiência compõe-se como uma matéria-prima da existência, daí o aparecimento da noção de experiência atrelada ao pensamento:

Estou outra vez diante da estação, mas na companhia de um senhor de certa idade; invento um plano para permanecer incógnito e também já vejo esse plano realizado. Pensar e experimentar são, por assim dizer, a mesma coisa. Ele simula ser cego, pelo menos de um olho, e eu lhe seguro um urinol masculino (que tivemos que comprar ou tínhamos comprado na cidade). Sou, portanto, um enfermeiro e preciso lhe dar o urinol porque ele é cego. Se o fiscal nos vir assim, nos deixará escapar por razões de discrição. Ao mesmo tempo, a postura da pessoa em questão e seu membro a urinar são vistos plasticamente. Depois acordo com vontade de urinar. (Freud, [1899]1900/2012, p. 232, grifo do autor) 
A partir dessa citação podemos nos perguntar: o pensamento é também uma experiência?

Numa nota de rodapé mais adiante no texto, Freud retoma a condensação de pensar e experimentar, num outro sonho seu, com um homem de mais idade, que provavelmente era seu pai, estava senil e precisava de um urinol. Havia, assim, uma inversão de papéis: o pai faz com o filho o que este fizera, anos antes, com o pai. Freud afirma que o motor do seu sonho foi uma frase de seu pai, quando ele se viu insatisfeito com a postura do filho que se recusou a ir ao banheiro antes de se deitar, e afirmou: "esse garoto nunca será alguém na vida." A inversão de papéis, no sonho, causada pelos dizeres do pai, faz um contraponto, como se dissesse: "Veja só, eu me tornei alguém na vida". Segurar o urinol fez Freud se lembrar da história do camponês que, experimentando várias lentes numa ótica, uma atrás da outra, não consegue ler. Podemos perceber, assim, que o sonho é uma experiência que corrige, trata ou repara outra experiência, ligando-se a esta, a partir de então, como uma nova unidade.

Freud relaciona pensar e experimentar com vontade e ato: na mesma nota ele recorre ao drama de Oskar Panizza, em que um velho paralítico, é tratado de forma ultrajante: "Nessa obra consta que para ele vontade e ato são uma coisa só, e seu arcanjo, uma espécie de copeiro dos deuses, precisa impedi-lo de xingar e de praguejar, pois suas maldições se realizariam imediatamente" (Freud, [1899]1900/2012, p. 238, grifo nosso).

Reunindo o pensar e o experimentar como uma coisa só, Freud encontra explicação para os sintomas histéricos ou descrição da culpa obsessiva, e toma como exemplo a imagem do urinol masculino:

Eu não precisaria explicar a um vienense o princípio das "mascaradas artísticas" típicas dessa cidade; ele consiste em produzir objetos de aparência rara e valiosa a partir de material trivial, de preferência cômico e sem valor, por exemplo, armaduras a partir de panelas, esfregões de palha e biscoitos salgados, tal como nossos artistas gostam de fazê-lo em suas noitadas de diversão. Pois bem, observei que os histéricos fazem exatamente igual; paralelamente àquilo que de fato lhes ocorreu, eles criam de maneira inconsciente acontecimentos fantasiosos medonhos ou extravagantes, que constroem a partir do material mais inocente e mais banal de suas experiências. Os sintomas dependem dessas fantasias, e não da lembrança de acontecimentos reais, sejam eles graves ou igualmente inocentes. (Freud, [1899]1900/2012, pp. 238-239) 
Seriam, portanto, as experiências passíveis de serem construídas num trabalho como as indicações textuais demonstram? Seriam passíveis também de ser reconstruídas, destruídas ou desconstruídas?

\subsection{A experiência no Projeto}

A noção de experiência aparece na teoria freudiana também em 1895, no Projeto de psicologia, texto ao qual Freud não se apegou, sendo considerado um escrito prépsicanalítico. Encontrado por Marie Bonaparte, que entregou o texto não acabado a seus editores, foi submetido a colchetes, parênteses e acréscimos de palavras de Strachey.

Freud apresenta a experiência de satisfação na parte I, item 11, logo após falar sobre o aparelho psíquico e o funcionamento da ação específica nesse aparelho — ação que pode ser a provisão de alimento numa criança faminta ou a aproximação de um objeto sexual.

O organismo humano é, no início, incapaz de levar a cabo a ação específica. Esta sobrevém mediante auxílio alheio: pela descarga sobre o caminho da alteração interior (como o berro da criança), um indivíduo experimentado adverte o estado desta. Esta via de descarga cobra assim a função secundária, importante ao extremo, do entendimento (Verständigung; ou comunicação) e o inicial desamparo do ser humano é a fonte primordial de todos os motivos morais. Se o indivíduo auxiliador operou o trabalho da ação específica no mundo exterior no lugar do indivíduo desvalido, este é capaz de consumar no interior de seu corpo a operação requerida para cancelar o estímulo endógeno. Todo o processo constitui então uma experiência de satisfação. (Freud, 1895/2004 p. 363; tradução nossa, grifo nosso).

Nosso destaque para a ação específica, auxílio alheio, desamparo, mundo exterior são para enfatizar a gramática da noção de experiência na psicanálise que gira em torno da perda de objeto e sua tentativa frustrada de recuperação. O Projeto é um texto com rupturas e inacabamentos e marcado por faltas, entretanto, um texto importante para a origem da noção de simbólico em psicanálise, como retomaremos com mais vagar posteriormente.

É preciso destacar uma diferença entre a apresentação da experiência de satisfação no texto do Projeto e no texto A interpretação dos sonhos. No capítulo VII 
deste, Freud se abstém de falar sobre o desamparo da situação infantil. No desmame há uma condição. A própria mãe precisa se desprender do trabalho de amamentar, como se supusesse que a criança não necessita mais daquele seio e daquela experiência para sobreviver. Isso não é nada simples, pois implica que a mãe tenha tido a experiência de ter ofertado ao seu filho o que supôs ser necessário. Mas, como o que ela lhe oferece não é somente seu leite, surge uma diferença na dinâmica de interpretação de satisfação do filho e desejo de satisfazê-lo. A mãe interpreta a seu modo, como lhe convém, e o filho terá que responder com algo que lhe é próprio. Nesse intervalo, nessa fronteira, vem o resultado. O bebê faz o desmame, mas somente se a mãe pôde abandonar a satisfação de doar o objeto. O resto não assimilável da experiência de satisfação é o resíduo conhecido como das Ding, a coisa. Se o objeto não se torna perdido,

(...) se ele não se destaca da coisa [das Ding], se ele não se presentifica como um resto, o sujeito não poderá fazer o luto pela perda do absoluto, ficando pois aprisionado a um gozo, signo de uma castração não sofrida e de um impedimento, ou uma dificuldade, na entrada do mundo e na ordem simbólica. (Peres, 1999, p. 100, grifo nosso)

Vemos assim como a noção de objeto em psicanálise consiste num modo relacional, ditando consequências psíquicas provenientes das ações das primeiras satisfações. Esse funcionamento e surgimento da noção de objeto em psicanálise nos autoriza a intercalar as noções em Freud a outros desenvolvimentos posteriores como os da noção de objeto em Lacan. O leitor observou que, na citação anterior, o gozo é imediatamente convocado para explicar o que acontece quando a perda não surge. Acreditamos que essa alternância teórica é benéfica, pois reconhece não ser possível eximir o surgimento de noções da teoria de Jacques Lacan, que retoma constantemente Freud em sua obra, o que justifica o título para esse capítulo.

Outra noção de objeto em Lacan que diz respeito à formulação do objeto $a$ entra no debate acerca da amamentação. Santo Agostinho oferece, em Confissões, a narrativa de uma cena em que uma criança entra em angústia e júbilo ao ver seu pequeno irmão bebê ser amamentado. A criança fica desconsertada, em seu ciúme e inveja; a mãe tenta realinhar a experiência e diz que ela, a criança, também esteve ali antes, mas o pequeno lhe responde: "mas eu não sabia". Esse exemplo, discutido por Lacan para falar do objeto pequeno $a$, demonstra como a memória e o esquecimento são elementos da experiência de constituição do sujeito, que essa experiência crucial "divide o sujeito ao 
mesmo tempo em que o unifica". (Lacan, 1968). Não era possível à criança reconhecerse na cena, que havia estado anteriormente no peito de sua mãe: tratava-se de uma experiência perdida, irrecuperável para ela, e apenas sorrateiramente alinhavada pela explicação afetuosa da mãe. O saber que não se sabe, o esquecido que retorna arbitrariamente, as formações do inconsciente, Freud demonstrou desde seu texto das Afasias como eles necessitam do aparelho de linguagem.

Na parte VII de A interpretação dos sonhos, quando Freud escreve sobre a realização de desejo, a experiência de satisfação aparece em relação às carências do sujeito da seguinte forma:

As carências da vida entram em contato com ele pela primeira vez sob a forma das grandes necessidades corporais. A excitação estabelecida pela necessidade interna buscará um escoamento na motilidade, que podemos chamar de "alteração interna" ou de expressão da emoção. A criança faminta chorará ou se debaterá desamparadamente. Mas a situação permanece inalterada, pois a excitação proveniente da necessidade interna não corresponde a uma força que percute de maneira momentânea, mas a uma que atua de maneira contínua. Apenas pode ocorrer uma mudança quando, por uma via qualquer - no caso da criança por meio de uma assistência alheia - se faz a experiência da vivência de satisfação que elimina o estímulo interno. (Freud, [1899]1900/2012 p. 593, grifo nosso)

É interessante notar que a experiência surge como uma possibilidade de que a mudança ocorra. Além disso, é preciso ressaltar uma diferença entre vivência e experiência. Queremos fazer valer a dificuldade do conceito em relação ao seu uso, como se pudéssemos provar que Freud escolheu bem a palavra. Podemos observar, na citação anterior, que o tradutor optou por manter a palavra "vivência" mesmo quando associada à experiência. Esta discussão implica um debate mais extenso, porque diz respeito à tradução das palavras Erfahrung e Erlebnis, experiência e vivência, respectivamente — ambas provenientes do alemão.

É a partir do latim que Larossa (2004) faz um estudo do termo que cabe bem em nossas considerações sobre Freud. Experiri significa "provar". Peri é encontrado também em periculum (perigo); e provém da raiz indo-européia per, que indica a ideia de travessia, percurso, passagem - e compõe, entre outras, a palavra peiratēs (do grego: pirata). Desse modo, para fazer valer a dificuldade do conceito em relação ao seu uso, como indicamos anteriormente, é importante observar a citação que se segue. 
o sujeito da experiência tem algo desse ser fascinante [pirata] que se expõe atravessando um espaço indeterminado e perigoso, pondo-se nele à prova e buscando nele sua oportunidade, sua ocasião. A palavra experiência tem o ex- do exterior, do estrangeiro, do exílio, do estranho e também o ex de existência. A experiência é a passagem da existência, a passagem de um ser que não tem essência ou razão ou fundamento, mas que simplesmente ex-iste de uma forma sempre singular, finita, imanente, contingente. Em alemão, experiência é Erfahrung, que contém o fahren de viajar. E do antigo alto-alemão fara também deriva Gefahr, perigo, e Gefährden, pôr em perigo. Tanto nas línguas germânicas quanto nas latinas, a palavra experiência contém inseparavelmente a dimensão de travessia e perigo. (Larrosa, 2004, p.162, grifo nosso) ${ }^{5}$

Pela acepção da palavra, e pensando-a com suas origens, vemos como Freud a utilizou a partir de uma ideia de trabalho, Arbeit, que compreende um ato, uma ação. Se observamos o conceito, sua função no aparelho psíquico tal como destacamos de Freud - partindo do fato, portanto, de que as carências da vida são absorvidas pelo sujeito através de vias corporais —, podemos aplicar aqui diretamente a explicação terminológica de Larossa para compreender a abordagem freudiana.

Num espaço indeterminado e perigoso em que o pequeno organismo humano se encontra, ele busca a oportunidade e a ocasião para tentar um estado de tranquilidade. E é do exterior e do estranho que ele busca a possibilidade de encontrar seu estado de satisfação desejado, que é, na verdade, a busca de um estado de inércia, de fuga ao desprazer. Essa contingência, na oportunidade e ocasião, formará os traços mnêmicos, traços que um dia comporão inconscientemente a escolha de objeto, a constituição da experiência moral — que fará o sujeito dizer "sim" ou "não", compondo sua ética particular.

Nos estágios mais primários da criança, para que o adulto satisfaça as necessidades dessa, que berra e tem fome, é necessário que ele reconheça que aquele berro signifique a ânsia por comida — ou, melhor dizendo, o leite materno. O Outro, para realizar o ato de reconhecimento, deve ter experimentado essa ausência anteriormente. A ação específica só pode ser realizada com o auxílio de outra pessoa. Por isso a expressão "sujeito experimentado", utilizada por Freud. Então, o que o adulto provê à criança fica bem mais explícito quando se considera que, dentro de uma

\footnotetext{
${ }^{5}$ Cf. também Jay (2005, pp. 10-12).
} 
vivência específica de necessidade, pode-se oferecer a sua satisfação — daí a tradução da expressão por "se faz a experiência da vivência de satisfação", como na citação do capítulo VII de A interpretação dos sonhos. Aparentemente, a vivência seria a satisfação das necessidades e a experiência, a expressão de todo o trabalho que esse processo implica. Experiências que tanto deixam suas marcas e traços em relação ao seu funcionamento que, depois de sucessivas vezes em que a criança berra, seu corpo e aparelho psíquico funcionam de modo a esperar pela satisfação anteriormente recebida.

Para Freud, quando a experiência de satisfação aparece em seus textos, surge como formadora do eu. Ela também surge relacionada à amamentação e à presença do outro.

Desse funcionamento que busca a satisfação original, e também a presença real do objeto, decorre também a experiência de dor. Se há um reinvestimento do objeto hostil, decorrente de uma frustração, por exemplo, surge um estado de desprazer com uma tendência à descarga. Isso nos coloca uma interrogação a mais, pois poderíamos nos perguntar: quais são as experiências mais difíceis de fazer? As de sofrimento e dor ou as de prazer? Essa tensão interna convoca que o organismo decida por uma determinada direção. A ação específica que visa a um objeto específico reduz a tensão. Entretanto, como o objeto se posiciona sempre como insuficiente, essa operação terá como resultado a insatisfação. A mediação entre a necessidade e o objeto que decepciona culmina na formação do desejo, ou seja, há uma interpretação entre a demanda de satisfação e o objeto. Se a necessidade busca uma satisfação, o desejo se manifesta na sua insatisfação, pois é incapaz de se satisfazer com tais objetos, buscando sempre novos. Esse aspecto do objeto, de não poder ser alcançado nunca, o torna indestrutível, ou seja, o psiquismo sempre funcionará buscando aquilo que não alcança.

Esse é o cerne da estrutura do desejo, onde se ligarão os embaraços da relação do sujeito com os outros ao longo da vida, fazendo a singularidade da formação de vínculos. Por isso a experiência de satisfação, lado a lado com a experiência de dor, prazer, desprazer e necessidade, inspirou Lacan no estudo das relações de objeto e na ética da psicanálise, onde surgem as bases para a noção de simbólico. Ainda em relação aos vínculos, Lacan busca em Freud a acepção de experiência no que diz respeito à dinâmica do desejo, mas ressalta o surgimento do moi [eu] proveniente desse processo: “...Em terceiro lugar, após ter visto, segundo sua prória estrutura, como o aparelho funcionava, reconstituindo os processos psíquicos elementares, o próprio 
funcionamento vai deixar marcas, isso que Freud chama de "a experiência". E consequência - essas experiências levarão à noção de eu". ${ }^{6}$

No seminário A ética da psicanálise, Lacan retoma a experiência de satisfação no que diz respeito ao resto não assimilável do aparelho, das Ding. Mencionamos das Ding anteriormente, no contexto do desmame, o seio como objeto perdido. No seminário da ética a experiência ocupa o lugar da complexidade da relação com o outro, o que Freud nomeou complexo do próximo, o Nebenmensch. O objeto para sempre perdido, por estrutura, impossível de reencontrar.

No mesmo seminário Lacan fala em experiência de dor, experiência de satisfação e experiência de alucinação, o que se coordena com as referências de Freud em 1895. Mas, curiosamente, dentre as experiências que estão demonstradas no aparelho de Freud, surge o que Lacan intitula experiência de fala —nomeação que não encontramos em Freud: "Não vemos absolutamente por que o desejo sexual e seus ciclos objetivados podem ser influenciados no que quer que seja numa experiência de fala, que a libido seja algo determinante no comportamento humano, isso não foi Freud que descobriu". 7

Essa experiência é o inconsciente estruturado como uma linguagem. Essa nomeação pode advir da consequência de tomar o texto de Freud a posteriori como fez Lacan, afinal, desde o texto das Afasias (1891) havia a proposta de um aparelho de linguagem. Acreditando que esse aparelho produz sintomas, haveria, assim, novos caminhos para a concepção do aparelho psíquico como no Projeto (1895).

O trilhamento da transformação da necessidade em desejo segue seu curso, na presença e ausência do outro, como no fort-da. A formação do aparelho simbólico no psiquismo se dá através das incidências de perda. Desde o trauma infantil, que interroga

\footnotetext{
6 “ Versão original: "Troisièmement, après avoir vu, d'après sa structure même, comment l'appareil fonctionnait, reconstituant les processus psychiques élémentaires, le propre fonctionnement va laisser des traces, ce que Freud appelle "expérience" Et — conséquence - ces expériences vont nous mener à la notion du moi" (Lacan, 1955, Staferla, 26 de janeiro).

${ }^{7}$ Versão original : "On ne voit absolument pas pourquoi le désir sexual et ses cycles objectivés peuvent être influences em quoi que ce soit dans une expérience de parole que la libido soit quelque chose de déterminant dans le comportement humain, ça n`est pas Freud qui l’a découvert" (Lacan, 1955, Staferla, 26 de janeiro).
} 
o estatuto de realidade das experiências, o trauma tem uma relação com a fantasia, com o real e com o ato, que nas referências utilizadas surge como ação.

O funcionamento da demanda entra numa série de desejo, necessidade e satisfação - que, quando não atendidos, provocam o que Freud chama de desamparo. Por isso a experiência de satisfação também aparece no Manuscrito E, que diz respeito à angústia e às demandas não correspondidas nos afetos sexuais. Freud deixa claro como a angústia dos neuróticos tem que ver com a sexualidade.

Então, a partir de certo valor, uma tensão sexual desperta libido psíquica, que logo leva ao coito, etc. Se a reação específica não pode produzir-se, cresce desmedidamente a tensão psicofísica (o afeto sexual), se transforma perturbador, mas ainda não há fundamento algum para sua mudança. Na neurose de angústia essa mudança sobressai, por isso aflora o pensamento de que aí se trataria do seguinte descarrilamento: a tensão física cresce, alcança seu valor de umbral com o que pode despertar afeto psíquico, mas por razões quaisquer a junção psíquica oferecida permanece insuficiente, é impossível chegar à formação de um afeto sexual — porque faltam para isso as condições psíquicas —: assim a tensão física não ligada psiquicamente se transforma em... angústia. (Freud, data imprecisa, 1894/2004, p. 232, tradução nossa, grifo nosso)

Observamos na citação anterior como a ação física busca uma tramitação psíquica que pode vir a gerar angústia. Nesse contexto, podemos inferir que a situação de desamparo, que, na ocorrência de uma vida, é provável que volte a surgir, liga a experiência de satisfação à experiência traumática. Para fazer essa passagem nos parece adequado o uso do conceito freudiano de "desamparo", Hilflosigkeit, que significa ausência de ajuda, "não ter ajuda", "não existe mais pai e mãe que protejam o indivíduo". As palavras "biológico", "satisfação" e "necessidade" jogam a força pulsional na economia psíquica e o desamparo, no eu. Laplanche e Pontalis designam o desamparo como um estado:

Propomos état de détresse (estado de desamparo), e não détresse (desamparo) simplesmente, porque se trata, para Freud, de um dado essencialmente objetivo: a impotência do recém-nascido humano que é incapaz de empreender uma ação coordenada e eficaz. (Laplanche, 1987/1992, p. 112)

O termo desamparo (Hilflosigkeit) designa a inconsistência biológica da criatura humana. Esse aspecto nos interessa porque nos aproxima do conceito de pulsão. Quando Freud fala do caráter econômico da operação que entrelaça a angústia realista à 
pulsional, ele afirma: "Quando o eu vivencia um estado de dor que não cessa, em outro momento um êxtase de necessidade que não pode achar satisfação, a situação econômica é, em ambos, a mesma, o desamparo motor encontra sua expressão no desamparo psíquico" (Freud, 1925/2004, p. 157, grifo nosso).

O desamparo motor é da ordem de uma ação e o desamparo psíquico é da ordem de um perigo. Essa afirmação consiste num funcionamento dialético que percorrerá nossa pesquisa. Ato e fantasia, na dialética das interpretações clínicas - como alguns de nossos relatos de análise irão demonstrar na última parte dessa pesquisa. Para desenvolver essa questão precisamos discutir, antes, a etiologia mista da neurose traumática - e, para tanto, vamos fazê-lo a partir do estudo das neuroses de guerra.

A ação e o perigo são os destaques de Freud como etiologia mista da neurose traumática. São também os aspectos que Freud valorizou, em 1937, no seu texto Análise terminável e interminável. É interessante observar como Freud, ainda no final de sua obra, recorre novamente à neurose de guerra e à neurose traumática.

Se apresentamos as primeiras experiências de satisfação relacionadas às experiências de perda, o que faremos a partir daqui é mostrar como - nos escritos de Freud sobre a neurose de guerra - também encontramos a experiência de perda, entretanto com um a mais: sua relação com o trauma e o luto. As experiências de perda nortearão a relação do sujeito com os outros, com os objetos, com seus ideais, ou seja, as coordenadas simbólicas do sujeito ao longo da vida, como vimos até o momento; mas esses aspectos demonstrados também surgem em Luto e Melancolia, texto escrito em 1915 e publicado em 1917. Freud faz referência à guerra em vários textos de sua obra, mas vale lembrar que sua obra foi influenciada pelas experiências traumáticas. A teorização gira em torno da teoria do objeto, e não somente em relação ao trauma e ao conflito. A perda de objeto talvez seja um dos pontos de maior riqueza do texto freudiano.

Teorizar a melancolia sempre foi uma preocupação de Freud. Segundo Urânia Tourinho Peres, no seu texto: Uma ferida a sangrar-lhe a alma, a insistência de Freud se deve na aposta em "atingir a compreensão da dor matricial, a dor que marcaria a entrada do infans em um mundo de desamparo e solidão" (Peres, 2011, p. 107). O que o leitor encontrará a seguir será o estudo feito por Freud da neurose traumática a partir da neurose de guerra. Dessa forma, faremos a importante passagem da teoria do trauma às 
experiências de perda e sua relação com o que Lacan chamou de real, que, como mostraremos, pode ser traumático ou terapêutico.

Tratando-se de experiência de perda, o texto Luto e Melancolia (1915), como afirmamos anteriormente, foi também escrito sob o impacto da Primeira Guerra Mundial. No mesmo ano Freud escreveu Reflexões para os tempos de Guerra e de Morte (1915), onde afirma que nossa relação habitual e convencional com a morte é alterada pela guerra. A eminência de uma situação devastadora como uma guerra coloca a existência concebida em termos do destino. Essa acepção de destino é bastante importante para a temática da experiência em torno do real. Vejamos como Freud recorre à neurose de guerra e à neurose traumática:

Por regra geral, há uma ação conjugada de ambos os fatores, o constitucional $e$ $o$ acidental. Quanto mais intenso for o fator constitucional, mais o trauma levará à fixação e deixará como sequela uma perturbação do desenvolvimento; e quanto mais intenso o trauma, mais seguramente exteriorizará seu prejuízo, mesmo segundo constelações pulsionais normais. Não há nenhuma dúvida de que a etiologia traumática oferece à análise, em muito, a oportunidade mais favorável. (Freud, 1937, p. 223, tradução nossa, grifo nosso).

O prejuízo corporal é mais favorável à recuperação do que perigo eminente. Nesse sentido, a palavra 'sequela' grifada por nós na citação anterior é de grande importância porque relaciona o constitucional com o acidental, e ainda marca a importância da ação (desamparo motor) e do perigo (desamparo psíquico). Em outras palavras, a ameaça de castração pode ser mais devastadora que a certeza desta. A palavra 'sequela' nos remete a uma continuidade, a uma castração que se fará presente no futuro, resistindo às tentativas de apagamento. A sequela também marca o início de uma constituição traumática, como se oferecesse ao psiquismo a matéria prima para as tramitações simbólicas ao longo da vida. Ainda acerca do constitucional e o acidental, podemos inferir que a experiência traumática possui uma íntima relação com a noção de real. Veremos, na última parte dessa pesquisa, nos relatos, o funcionamento da contingência do objeto, presente nas primeiras teorizações de Freud sobre a experiência de satisfação.

O trauma é o grande modelo psicanalítico para a perda ou negação da experiência. Os sobreviventes que apresentavam um ferimento visível, uma dor física, passível de ser tratada organicamente, formavam um quadro específico de um tipo de 
experiência de cura. Já as experiências de difícil elaboração, quando sofriam do estresse da batalha sem dores físicas, contavam com um diferente mecanismo de elaboração psíquica daqueles que tiveram ferimentos. Esse mecanismo psíquico nos revela um caráter intersubjetivo do trauma, e sua dependência, ligação e subjetivação derivadas do Outro. Assim, podemos observar que o trauma pode não produzir efeitos imediatos, recebendo o recobrimento da fantasia; e que a noção de trauma diz respeito ao estatuto de realidade e real em psicanálise. Se, como citamos anteriormente - do Manuscrito $E$ - a ação física busca uma tramitação psíquica que pode vir a gerar angústia, no caso de um perigo realístico há uma oposição entre a realidade e a neurose como destinos para a angústia.

Para reforçar a importância desse aspecto de real em relação ao trauma e a fantasia, no que diz respeito à neurose, recorreremos a uma passagem de Moisés e o monoteísmo:

Em relação às propriedades ou particularidades comuns aos fenômenos neuróticos, corresponde destacar dois pontos: os efeitos do trauma são de índole dupla, positivos e negativos. Os primeiros são empenhos para devolver ao trauma sua vigência, vale dizer, recordar a experiência esquecida ou, ainda melhor, torná-la real-objetiva (real), vivenciar novamente uma repetição dela: toda vez que se tratar de um vínculo afetivo anterior, fazê-lo reviver dentro de um vínculo análogo com outra pessoa. (Freud, 1939/2004, p. 72, tradução nossa, grifo nosso)

Observando a citação anterior, vale retomar a palavra 'sequela' que nos remete a uma continuidade, a uma castração que se fará presente no futuro, resistindo às tentativas de apagamento, como se fosse uma compulsão à repetição. A sequela também marca o início de uma constituição traumática, como se oferecesse ao psiquismo a matéria prima para as tramitações simbólicas no decorrer da vida. Ainda acerca do constitucional e o acidental, podemos inferir que a experiência traumática possui uma íntima relação com a noção de real. Por isso podemos afirmar que o trauma é o grande modelo psicanalítico para a perda ou negação da experiência, pois os efeitos positivos do trauma conduzem à compulsão à repetição, os efeitos negativos aparecem em reações de defesa. Daí a dificuldade de saber se o silêncio do sujeito corresponde ao caso positivo ou negativo do trauma. Ambos os efeitos dizem respeito a uma fixação. Na tentativa de se livrar das "sequelas", o sujeito, compondo a sua realidade, se utiliza da fantasia como mediadora de todo esse trabalho. Para não ser completamente invadido 
pelo real, o sujeito utiliza a realidade como mediadora. Veremos na última parte dessa pesquisa, nos relatos, o funcionamento da contingência do real, a relação com o objeto e a dissolução do sintoma.

Como tratamos do desemparo anteriormente, a partir das primeiras experiências de satisfação e insatisfação do sujeito, podemos afirmar o caráter inespecífico do trauma, e seu tratamento dependerá da posição da neurose (positiva ou negativa). Entretanto, o real da fantasia é de antemão estabelecido, condicional. Retomando as colocações anteriores, o real (ação), é diferente do real do (perigo), este último já é uma consequência de um trabalho psíquico causado pelo anterior.

Neste momento da pesquisa, nesta constelação conceitual, faremos uma digressão para mostrar como o conceito de elaboração é trabalhado na obra freudiana. Depois disso, poderemos dar maior ênfase à noção de objeto relacionado ao real clinicamente.

O conceito de elaboração pode ser rastreado nos textos freudianos, quando estes se referem ao modo como o psiquismo reage diante do trauma. Assim, desde os Estudos sobre a histeria (1895), o não querer saber da histérica, revelado na dificuldade de associação, dificultava o trabalho de elaboração (Verarbeitung), por uma espécie de falha da memória, uma suspensão da rememoração.

Não é simples definir o conceito de elaboração em psicanálise. A palavra Arbeit é encontrada em várias outras definições da obra freudiana; trabalho do sonho (Traumarbeit); trabalho de luto (Trauerarbeit); perlaboração (Durcharbeit). Quando se trata de Arbeit, Freud indica, com isso, uma quantidade de trabalho que o psiquismo exige, e a elaboração parece apresentar o conjunto dessas operações. A elaboração é um dos conceitos psicanalíticos que compreende a ideia de refazer, recompor uma experiência.

A manifestação mais evidente do trauma, o que se apresenta como sofrimento terrível ao sujeito traumatizado, é que ele não consegue deixar de pensar e lembrar daquela situação traumática. Ela se repete em sonhos, pensamentos e associações. Ele é tomado pelo evento traumático insistentemente. E aqui vale lembrar a definição do inconsciente como trabalhador incansável. Esse funcionamento, que também podemos associar o trabalho de luto, que será discutido no próximo capítulo através de experiências de perda. 
Se, por um lado, a lembrança faz existir o evento na cena psíquica, é essa mesma lembrança que, incessantemente, volta à consciência, revelando o objeto de amor perdido. É como se a própria memória se tornasse a fonte do problema, sobreinvestida em sua função. Encontramos aqui o problema freudiano original acerca das relações entre o lembrar e o prazer/desprazer. Entre esquecer o desprazer e lembrar o prazer, como é possível a seletividade da memória? Essa é a pergunta que levará Freud a formular o recalcamento (secundário) e a concepção de trauma.

Na Carta 52 de Freud a Fliess está a proposta do aparelho psíquico - aparelho de memória, em que um traço mnêmico necessita ser traduzido de um registro a outro até chegar à consciência. A falha nessa tradução é o recalque. É interessante observar que, em ambos os processos — o de tradução ou a sua falha —, o desprazer é liberado. Clinicamente, a rememoração apresentada na associação livre, regra fundamental da psicanálise, traz os retornos do recalcado através da fala do paciente. O falar é fazer trabalhar, e falar ao outro na cena psicanalítica representa o trabalho necessário à economia da lembrança. Rememorar para colocar em trabalho a lembrança que causa o sofrimento.

Outro aspecto importante na clínica, que Freud nos apresenta desde o Projeto e a Carta 52, é a noção de temporalidade, a sucessão dos acontecimentos. A "consciência secundária do pensamento é posterior no tempo" (nachträglich) (Freud, 1896/ 1986, p. 283). A consciência da experiência faz parte da experiência. As lembranças relativas às experiências sexuais, que Freud investiga naquele momento e que são condição para o recalque - a falha de tradução — , podem se tornar patogênicas: esse é o efeito $a$ posteriori (nachträglich). $\mathrm{O}$ tratamento psicanalítico conta com esse efeito no psiquismo para que aconteça o trabalho clínico, o trabalho de ressignificação. A articulação significante na experiência psicanalítica justifica o trabalho psicanalítico como recomposição entre memória, afeto, linguagem, tempo e consciência.

Qual analista não observa os comentários de seus analisantes em relação aos acontecimentos do mundo? O dia dos namorados pode ser tão devastador quanto um 11 de setembro. A psicanálise não pode oferecer a interrupção instantânea do sofrimento, mas os analistas dizem: "fale-me mais sobre isso" — quase como se dissessem: "conteme tudo aquilo de que você se lembra", para depois ser possível esquecer. A interrupção do sofrimento se alinha à capacidade de esquecer, o que nos coloca diante da função terapêutica da lembrança e do esquecimento. Mas o que interessa em todas as 
configurações possíveis acerca da memória é que a capacidade de esquecer, rememorar, serve para reconstruir. A história não é o passado, a história é o passado enquanto ele é historicizado no presente.

A restituição da integralidade do sujeito, disse-lhes há pouco, apresenta-se como uma restauração do passado. Mas o acento recai sempre mais sobre a face da reconstrução que sobre a face da revivescência, no sentido que estamos habituados a chamar de afetivo. O revivido exato - que o sujeito se lembre de algo como sendo verdadeiramente dele, como tendo sido verdadeiramente vivido, que se comunique com ele, que o adote - temos nos textos de Freud a mais formal indicação de que não é o essencial. $O$ essencial é a reconstrução, é o termo que ele emprega até o fim. (Lacan, $1954 / 1996$, p. 23)

Podemos observar a acepção de verdade que Lacan convoca na citação anterior. Não é essencial que o sujeito se lembre exatamente como foi. Disso podemos inferir que existe nesse contexto uma abertura à uma ficcionalidade, a uma invenção.

Há aí algo absolutamente notável, e que seria paradoxal se, para aceder a isso, não tivéssemos a percepção do sentido que isso pode ter no registro da palavra, que eu procuro aqui promover como sendo necessário à compreensão da nossa experiência. Direi- afinal de contas, o que se trata é menos lembrar do que reescrever a história. Falo a vocês do que há em Freud. Isso não quer dizer que ele tenha razão, mas essa trama é permanente, continuamente subjacente ao desenvolvimento do seu pensamento. Ele nunca abandonou algo que só se pode formular da maneira que eu acabo de dizer reescrever a história - fórmula que permite situar as diversas indicações que ele dá a propósito dos pequenos detalhes nos relatos de análise. (Lacan, 1954/1996, p. 23, grifo nosso)

Dessa citação, nossos grifos mostram uma incidência dos formadores da experiência: a escrita. Retomaremos esse aspecto posteriormente, quando formos tratar dos relatos das experiências de análise. Além disso, a citação mostra a importância de se tentar compreender a experiência, e de como os relatos podem contribuir para isso.

Quando Freud abandona a hipnose e escreve sobre a diferença entre o tratamento sugestivo e o analítico, era 1905, e recorre a Leonardo da Vinci para escrever sobre essa antítese entre esses dois métodos. Trata-se do texto: Sobre psicoterapia (1905). Nas fórmulas de Da Vinci em relação às artes, afirma que a pintura trabalha per via di porre, pois deposita sobre a tela incolor partículas que não estavam lá. A escultura trabalha per via di levare, pois retira da pedra tudo o que encobre a superfície da estátua nela contida. Na sugestão, como na pintura, se deposita algo, como os borrões de tinta. Na técnica 
analítica não se pretende acrescentar nada; ao contrário: reduzir, retirar. Se Freud abandonou a sugestão é porque achava que nessa técnica a ideia patogênica poderia retornar; na técnica analítica, a meta é a remissão desses sintomas.

A partir dessa ideia da capacidade de falar de si e a relação da fala com a Arbeit, e colocando o trauma na acepção da angústia, nos interessa o que Jacques Lacan afirma no seu seminário da Angústia, na aula de 12 de dezembro de 1962: “A linguagem é trabalho".

Eu pensava ter-lhes trazido, mas não encontrei em meus papéis, a frase de Hegel na Fenomenologia do Espírito que lhes fornecerei da próxima vez, na qual se diz formalmente que a linguagem é trabalho e que é por ela que o sujeito faz seu interior passar para o exterior. A frase é tal que fica bem claro que se trata de inside out, como se diz em inglês. Trata-se realmente da metáfora da luva virada pelo avesso. Mas, se acrescentei à essa referência a ideia de uma perda foi na medida em que alguma coisa aí não sofre essa inversão, na medida em que em cada etapa sobra um resíduo, que não é passível de inversão nem tampouco de significação no registro articulado. (Lacan, 1962, p. 78, grifo nosso)

Essa passagem de Lacan nos fornece elementos para retomar o debate sobre falar e recordar, ou seja, lembrar para esquecer. Nesse sentido, Mezan afirma:

Aquilo que foi excluído não desaparece por ter sido excluído. Retorna sob a forma de repetição, desencadeando os movimentos transferenciais que ritmam a análise. É por meio da análise da transferência, dos seus padrões típicos em cada pessoa, dos desejos que nela se atualizam, das defesas que ela mobiliza e que se revelam através dela, que o psicanalista pode formar uma ideia aproximada daquilo que foi reprimido, e cujo aspecto "exterior" é estar em regime de esquecimento. (Mezan, 1993, pp. 77-78.)

Adiante, no mesmo texto, Mezan nos surpreende, quando afirma que o que se deveria dizer é inquecer, e não esquecer.

Pois só mediante o inquecimento do silenciado é que os fantasmas podem encontrar repouso: é reinvestindo-os pelo trabalho do luto, in-umando-os através de sua circulação pela psique, e não colocando-os à distância por meio de um pseudo "entendimento desapaixonado". (Mezan, 1993, p. 79)

Recordar é colocar em movimento, fazer trabalhar, working through, trabalhar pelos caminhos que a transferência proporciona. Assim, o termo utilizado por Mezan, inquecer, questiona o prefixo ex-, de "cair para fora". Aceitar a condição psíquica é 
aceitar o inconsciente, a natureza enigmática da acepção da memória. Assim, as lembranças devem cair para dentro, e não para fora, compondo e favorecendo o funcionamento da elaboração.

Sobre os caminhos e os descaminhos que a transferência proporciona, há uma citação do Seminário do Ato psicanalítico, na aula de 7 fevereiro de 1968, em que Lacan ressalta a importância da elaboração na teoria:

[...] Em todo caso, uma coisa é certa, é que não há psicanalista sem psicanalisando; e diria mais, a respeito de algo tão singular que tem entrado no campo de nosso mundo, a saber, que haja um certo número de pessoas de que não estamos certos que isso tenha o poder de instaurar seu estatuto como sujeito, e que, apesar disso, são pessoas que trabalham nesta psicanálise. O termo "trabalho" não foi excluído por um só instante desde a origem da psicanálise, o Durcharbeiten, ou working through... esta é precisamente a característica a que temos que nos referir para admitir a aridez, a secura, às vezes até as incertezas e suas margens. (Lacan, 1968, pp. 137-138, grifo nosso)

Quando Lacan retoma Hegel e afirma que "a linguagem é trabalho e que é por ela que o sujeito faz seu interior passar para o exterior", a metáfora da luva parece indicar que o que não sofre a inversão do inside out da luva retirada são os traços, os restos. O trabalho da memória não é o de fazer sobreviver uma experiência, e sim permitir que ela seja esquecida para permanecer simbolicamente eficaz nesse esquecimento, apta a ser lembrada. Daí o seu elemento residual aparecer no detalhe lateral da recordação, como foi a lembrança de Hans do nome da cidade onde passava as férias de verão e onde iniciou a sua fobia. Essa lembrança foi a única que lhe restou da época de seu sintoma. É interessante observar que o nome dessa cidade, "Gmunden", está contido no primeiro nome de Freud: Sigmund.

O sofrimento é singular e incomparável, o trauma é sempre a posteriori, e é preciso estar vivo para narrar. Mas, para além da regulação e funcionamento da memória no psiquismo, do esquecimento, há, como mostramos, a invenção - e a narrativa ocupa esse lugar. Esses questionamentos nos levam a pensar no lugar da psicanálise e da literatura, nas possíveis aproximações e devidas distinções. Para cada uma há um entendimento de trauma. Na psicanálise, é possível discutir a dimensão de verdade, da verdade inventada que há no tratamento analítico, porque o trauma do sujeito passa pela sua interpretação e o analista, através da transferência, acompanha esse atravessamento da fantasia fundamental ou da verdade mentirosa. $\mathrm{O}$ espanto do 
sujeito com aquilo mesmo que diz demonstra isso, apontando uma responsabilidade sob seus ditos. $\mathrm{Na}$ interseção possível entre a literatura e a psicanálise, vale destacar a importância de demonstrar o inapreensível da experiência, para não cair numa espécie de relatos sem afeto, ou com afetos demais.

Nossa preocupação, e da qual nosso texto se ocupará com mais vagar posteriormente, é não deixar de assinalar que tanto a psicanálise quanto a literatura são formas de tratamento do real, e que nenhuma assume uma forma privilegiada desse tratamento. São vias de sustentar a experiência da divisão subjetiva e tratar o real pelo simbólico para conter a compulsão à repetição.

Os relatos de experiências, portanto, aproximam-se daquilo que chamamos de hystoire, historicização, o tratamento do trauma, pela via do tratamento da angústia. Trauma e o luto são dois modelos de perda e de recomposição da experiência. Por isso nos interessam as experiências de análise e as experiências de perda, pois essas situamse aí na invenção, na reconstrução e, portanto, na historicização. No início da psicanálise, no trabalho com as histéricas, ficou demonstrado que a experiência universal do sofrimento psíquico poderia ser narrada. Freud escreveu seus casos clínicos sem deixar de destacar a perda da experiência posta na escrita; e, numa carta a Jung, afirma: "Que embrulhada quando tentamos descrever uma análise! Que lástima despedaçar o grande trabalho artístico que a natureza criou na esfera psíquica"! (Freud, 1906/1909, p.317) As histéricas lhe falavam porque a característica destas era unir as palavras às lembranças, e assim foram construídos todos os pilares da clínica psicanalítica.

Nas palavras de Jeanne-Marie Gagnebin - no texto "Verdade e memória do passado" - , baseada na concepção de história de Walter Benjamin, essa seria a tarefa do historiador: "é necessário lutar contra o esquecimento e a denegação, lutar, em suma, contra a mentira, mas sem cair em uma definição dogmática de verdade" (Gagnebin, 2004, p. 44). Daí a analogia entre o historiador-arqueólogo e o psicanalista, ambos tentam recompor a experiência.

Não é possível deixar passar a importância do "ex" de experiência, o "ex-" do exterior, do estrangeiro, do exílio, do estranho. Koltai (2000) toma o conceito de estrangeiro e demonstra como o não familiar se tornou um termo sócio-político. Através da diferença, do que há no outro que identificamos em nós e que gostaríamos de 
esconder de nós mesmos, mostra como a teoria da interioridade e da exterioridade funcionam. A psicanálise, através desse paradigma, estabelece a importância da presença e da ausência do Outro: "Estrangeiro a si mesmo, essa pode ser uma denominação para delimitar a posição do neurótico, do psicótico ou do perverso, na medida em que cada um deles, em sua posição, se encontra em exílio relativamente a seu estatuto de sujeito" (Koltai, 2000, p. 27).

Koltai cita Leclaire (1996), que afirma que "o curioso da situação psicanalítica é ter proposto para nosso século um novo lugar de asilo para a palavra verdadeira, que se conjuga em três - eu, tu, ele - e em que nenhum termo pode se conjugar sem os demais" (apud Koltai, 2000, p. 28). No enodamento entre o eu, tu, ele, o que nos importa salientar é a gramática da demanda proveniente dessas ligações.

A fronteira, um dos nomes do estranho, é aquela que marca a diferença. Quanto à etimologia de fronteira, Koltai faz uma contribuição bastante importante para mostrar como é necessário uma exterioridade para uma nomeação:

Fronteira, entendida como uma projeção topológica sobre o lugar de uma realidade social, é aliás um termo que - segundo o levantamento feito por G. Garner (1996, pp. 207-208) - representa o ponto de ruptura de uma lei e tem a particularidade de já ser, na maioria das vezes, nomeada na língua do vizinho. Assim, a palavra grenze, em alemão, teria sido tomada de empréstimo aos vizinhos eslavos, a palavra frontière, em francês, viria do latim frons, utilizado pelos romanos para indicar a fronteira espanhola, enquanto o border inglês viria da bordure francesa. A fronteira é, assim, sempre nomeada na língua do Outro. (Koltai, 2000, p. 21)

Podemos dizer que essas considerações sobre o "ex-" de "estranho", "estrangeiro" nos dá elementos para ilustrar nossos propósitos. Do caráter relacional da demanda, das relações e fronteiras com o outros (eu, tu, eles) surgem as queixas que posteriormente veremos como solidão, vazio, tédio, demarcando um terreno de perda da experiência.

Com o caminho percorrido até aqui, mostramos como a noção de experiência implica uma costura, ou, como gostaríamos de propor, a criação de uma discursividade sobre ela. Isso não era a primeira intenção e objetivo desta pesquisa, mas, em virtude da ausência de um debate específico sobre a noção de experiência em psicanálise - tal como ela é utilizada em Freud e Lacan -, o texto acaba por sofrer o que chamaremos 
de uma "consequência discursiva", em que todo o tempo será passível de uma citação em que a noção surja para se adequar ao seu uso.

Com a introdução da noção de experiência na teoria psicanalítica — percebe-se que a experiência é uma palavra paradigmática da complexidade da relação com o Outro, no funcionamento do destino do sujeito, qual seja, eternamente em presença/ausência desse Outro. Em relação às fronteiras entre o eu e o Outro, observamos uma passagem importante no texto Mal-estar na civilização:

Normalmente nada nos é mais seguro do que o sentimento de nós mesmos, de nosso Eu. Este Eu nos aparece como autônomo, unitário, bem demarcado de tudo o mais. Que esta aparência é enganosa, que o Eu na verdade se prolonga para dentro, sem fronteira nítida, numa entidade psíquica que denominamos Id, à qual ele serve como uma espécie de fachada- isto aprendemos apenas com a pesquisa psicanalítica, que ainda nos deve informar muita coisa sobre o Eu e o Id...No auge do enamoramento, a fronteira entre $\mathrm{Eu}$ e o objeto ameaça desaparecer. Contrariando o testemunho dos sentidos, o enamorado afirma que Eu e Tu são um, e está preparado para agir como se assim fosse. (Freud, 1930/2011, p. 9, grifo nosso)

Destacamos a demarcação das fronteiras do eu. $\mathrm{O}$ texto freudiano trabalha $\mathrm{o}$ mal-estar na civilização e o do sujeito, pois o que se observa na clínica recorrentemente é a busca do sujeito por um objeto fixo, determinado, mesmo que estas qualidades não conduzam à cura. Num tratamento, na produção de uma experiência, mesmo reconhecendo que há uma experiência para sempre perdida, a experiência de análise não é apenas redescobrir o que estava encoberto, mas é também uma criação. Numa análise, o limite, a borda, o encontro com o real, estarão sempre em questão, por isso "o real é o limite de nossa experiência" (Lacan, 1956/1957, Staferla, p.32).

Uma vez tendo recorrido à noção de fronteira, de limites, de estrangeiro, podemos afirmar que há, nessa fronteira, uma borda. Nesse intervalo, nesse limite está o que Lacan chama de borda do real, e é neste lugar onde localizaremos a escrita no próximo capítulo. Aqueles que tentam escrever tentam justamente habitar esse espaço da experiência humana, aqui concebida como existência.

O furo que possibilita que se borde tramita entre dois espaços, entre um eu e um tu; as palavras buscam algum sentido, na teoria, na clínica, desde que se escreva, na impossibilidade de que o real não venha a ser simbolizado - esse impossível que "não cessa de não se escrever", como formulado por Lacan. Assim, propomos que este 
primeiro capítulo tenha sua continuidade no último, quando apresentaremos os relatos, onde uma análise mais detalhada dos efeitos do real poderá ser observada na escrita daqueles que se propuseram a escrever sobre sua experiência de tratamento.

Entretanto, pensando no que se pode afirmar acerca do que apresentamos e discutirmos acerca dos traços e condições da experiência em psicanálise, aquilo que está em jogo numa experiência é algo do qual não se imagina - a experiência tem esta familiaridade com o real porque este não é antecipável ao sujeito. Por isso a noção de experiência é trabalhada lado a lado com a noção de perda, de objeto e de trauma onde os registros imaginário e simbólico "chegam” depois. A experiência estará sempre articulada no campo do acontecimento real. 


\section{Capítulo 2. Experiência sensível: escrita e experiências de perda}

Afirmamos como objetivo desta pesquisa, estudar a noção de experiência para entender os relatos de análise e estudar os relatos de análise para compreender a noção de experiência. Nesse movimento dialético, trabalhamos no primeiro capítulo a teoria de objeto marcada por uma falta, compondo as primeiras experiências do sujeito, e a importância das perdas constitutivas de tais experiências. Neste capítulo vamos trabalhar as condições da escrita para colocar em palavras aquilo que resiste ser representado por elas. E aqui a noção de representação marca sua importância porque é a tentativa de representar o que está ausente.

Em relação ao processo de reconstituição da experiência, destacamos na introdução: "Eu diria que, no final das contas, o que realmente se trata é menos de se lembrar do que de reescrever a história". (Lacan, 1954, p.23, trad. modificada). A primeira parte deste capítulo trabalha modos de linguagem como a narrativa e a escrita, para em seguida, serem representados pela escrita sobre o luto. A escrita, mas também a experiência sensível, parecem ser condições que produzem uma espécie de mediação entre as experiências de perda e a perda de experiência.

\subsection{Escrita}

Seria excessivo desenvolvermos em nossa pesquisa uma extensa apresentação acerca da linguagem em psicanálise, entretanto, como nosso trabalho se baseia em relatos escritos e na escrita de experiência de perda, precisamos fazer um recorte teórico no que concerne à experiência de escrita. E o ponto comum na escrita, entre a perda e o objeto, é o estilo. Trataremos da escrita em relação ao real e também em relação à uma experiência de transformação, da escrita teórica e científica, portanto mediadoras, e da relação entre a transmissão e a forma desta. Ao longo deste capítulo faremos alusão ao capítulo dos relatos de análise porque precisaremos na noção de escrita trabalhada aqui para a leitura dos mesmos.

Estamos diante de um problema importante, porque a experiência analítica concerne a uma experiência de linguagem; e nesta tese não estamos falando de associação livre, de fala plena ou fala vazia, em relação à clínica, mas de uma 
experiência específica que é a escrita de uma experiência de análise. Nosso interesse recai sobre a produção escrita (relatos e experiências de perda), embora reconheçamos o ensino oral de Lacan e o interesse desse autor em relação às práticas discursivas de bem-dizer e semidizer.

Em essência, a experiência analítica é uma experiência de linguagem. Evidentemente que esta linguagem que especifica a experiência analítica é a linguagem dos nossos desejos e de nossas fantasias inconscientes. Na experiência analítica, tudo se deve dizer e nada fazer se não dizer. Na força criativa do dizer, o diálogo analítico empenha o sujeito em um trabalho que é mais do que um 'conhecimento de si', é uma verdadeira construção, ou (re)construção, por meio da qual o sujeito tenta 'tornar-se aquilo que é', ou melhor ainda, tenta fazer 'seu' o ser que ele é. (Rocha, 2008, p. 105, grifo nosso)

A citação anterior localiza nosso problema da proposta de trabalhar com a escrita, pois afirma o pressuposto de que a experiência analítica concerne à linguagem. Entretanto, nos dá a chave que nos faz seguir adiante no que concerne ao conhecimento de si como uma construção. Se é possível reconstruir para tentar "tornar-se aquilo que é”, por que a escrita estaria fora dessa construção? Se uma das acepções de experiência diz respeito a uma forma de saber, são necessárias as experiências com o outro, e com os objetos, ao longo de uma vida para saber-se de si. Além disso, vale lembrar uma citação de Lacan nos Outros escritos, em que, tomando o Bem-dizer, como uma ética, essa diz respeito à fala e à escrita teórica: "extrai da minha prática a ética do Bem-dizer" (Lacan, 1973, p. 539). Com isso posto, margeamos a problemática do silenciamento do sujeito ou a tagarelice. Vejamos a citação de Lacan, sobre a fala plena:

A fala plena é aquela que visa, que constrói a verdade tal como ela é estabelecida no reconhecimento de um pelo Outro. A fala plena é o que faz ato. Um dos sujeitos se vê, depois como um outro que ele não era antes. É por isso que essa dimensão não pode ser evitada na experiência analítica. (Lacan, 1956, p. 125, grifo nosso.)

Desse modo, a fala vazia, em sua oposição, não faz ato e Lacan aparentemente a nomeia somente para caracterizá-la negativamente em relação à plena.

Vale lembrar que uma das incidências da noção de experiência em Lacan é a experiência da palavra. Seja ela dita ou escrita. A palavra dita reordena o escrito. E o 
escrito reordena o dizer. "Estilo e retórica fazem parte de um saber que implica uma espécie de ética do bem-dizer (Lacan, 1973, p. 539); com isso, podemos pensar: a força da retórica dita transforma o sujeito tanto quanto a força da retórica escrita. No social, essa força observa seu valor na escrita testemunhal, que, impossibilitado às vezes de falar o que tem a dizer, precisa aparecer escrito. Ainda que a força dos escritos valha bastante bem para a transmissão futura, isso também é uma consequência da perda de valor da oralidade, do discurso oral, passado de geração em geração, como demonstra o texto de W. Benjamin Experiência e pobreza.

Os desenvolvimentos anteriores no capítulo 'traços e condições de experiência' em psicanálise demonstraram como, no modo de relação imaginária, o desejo do sujeito se aliena no outro. Isso significa que, a partir do surgimento do simbólico, o sujeito pode contar com a linguagem. A citação a seguir parece condensar nossos argumentos:

No momento da experiência, o sujeito entra em comunhão com o objeto e o interioriza no ato de conhecer. Assim interiorizado, o objeto começa a fazer parte da sua vida e o marca na sua singularidade de sujeito. Em seguida, pela mediação da linguagem, o sujeito traduz e comunica aos outros a riqueza daquilo que potencialmente se esconde nos objetos. Ao homem, enquanto ser que pensa e que fala, cabe o privilégio de fazer falar as coisas, ou de lhes emprestar a linguagem para que elas digam o seu segredo. E isso não é apenas um dom especial daquele que é poeta, porque também os demais seres humanos, sejam eles cientistas ou não, por meio da linguagem, revelam o segredo das coisas. Objeto e sujeito são, portanto, os polos estruturantes da noção de experiência, sobretudo da experiência enquanto forma de saber. (Rocha, 2008, p. 104, grifo nosso)

A experiência se estrutura em um polo objetivo relacionado ao objeto, e um polo subjetivo que é a consequência do primeiro. O objeto, portanto, se apresentando infinitamente ao longo de uma vida, resulta numa experiência ambígua, pois nem sempre o polo subjetivo encontra palavras para descrever o que ocorre no polo objetivo. Daí podemos recorrer aos aforismas lacaniano de que "o real não cessa de não se escrever" e que o "real é o impossível". Entretanto, nesses impasses de bordear essa fronteira entre o sujeito e objeto, surgem sempre novas tentativas, que têm efeitos subjetivantes. Assim se localiza a ideia de que a noção de estilo em Lacan diz respeito ao objeto.

Destacamos também na citação anterior a experiência enquanto forma de saber. "Se as Luzes fazem furo, é a letra que desenha a borda do furo no saber" (Lacan, 1970, 
p.18), tal como apresentamos o sujeito moderno na introdução. Em outra forma de dizer: "Tanto quanto, ao me deslocar para o polo oposto, metafórico, da busca significante, e ao me devotar a tornar-me o que sou, a vir a sê-lo, não posso duvidar de que, mesmo ao me perder nisso, é aí que estou" (Lacan, 1957, p. 521, grifo nosso).

Quando se diz que o sujeito traduz e comunica aos outros, o autor explora a porção de realidade nesse processo, ou seja, os problemas na vida do sujeito que são decorrentes da relação entre sujeito e objeto. Assim podemos inferir que há algo homogêneo entre a fala e a escrita, e essa homogeneidade tem, para nós, um estatuto de uma questão. Assim, como não pretendemos esgotá-la, aproximamo-nos dela pela tradução.

A primeira questão que convoca o leitor acerca da tradução é o que diz respeito da passagem de uma língua a outra. Mas aqui a palavra passagem ocupa seu lugar, daquilo que passa, que atravessa outra forma de representação. "A impureza do limite e a insuficiência angustiante da tradução" (Derrida, 2000), passar de uma língua a outra, envolve uma perda. E não está somente na passagem de uma língua a outra, mas também na escuta ou escolha de um significante em detrimento de outro.

Retomando a citação anterior de Rocha no que diz respeito à tradução: "pela mediação da linguagem, o sujeito traduz e comunica aos outros a riqueza daquilo que potencialmente se esconde nos objetos". A experiência estrangeira da linguagem pode acontecer dentro da própria língua. Escutando palavras como clínicos, acabamos por eleger alguns significantes, e isso nos levou ao texto de Derrida intitulado "O que é uma tradução relevante?" - no qual a palavra relevante ganha mais força do que o próprio ato de traduzir.

O que se esconde nos objetos vai buscar passar para a palavra. Nesse contexto, introduzimos o conceito como um significante. Entretanto, as extensões discursivas dos conceitos não deveriam esconder como se dão os problemas e sofrimentos decorrentes do funcionamento entre sujeito e objeto. "A teoria é boa mas não impede que os fatos existam” (Freud, 1893, 1969, pp. 22-23).

Assim, esse capítulo ocupa uma posição de interseção entre as experiências de perda e a perda de experiência; porque, se há perda de experiência, é porque houve anteriormente uma experiência de perda. Procuramos justificar o uso da literatura e da poesia nessa pesquisa e a teorização possível e concernente à escrita, ao objeto, ao estilo, 
à borda do real. Portanto, localizamos alguns momentos na obra de Lacan, onde a escrita se coordena à linguagem e ao real. "A escrita me interessa, posto que penso que é por meio desses pedacinhos da escrita que, historicamente, entramos no real, a saber, que paramos de imaginar. A escrita de letrinhas matemáticas é o que suporta o real" (Lacan, 1975/ 1976, 2007, p. 68).

Desse modo, podemos perceber que estamos falando de dois tipos de escrita a que a experiência de linguagem concerne: a escrita teórica e a escrita da mediação. Ambas são mediações entre o sujeito e objeto e ambas buscam uma transmissão, um trabalho de tradução. Essa mediação proporcionada pela escrita é o que se chama de borda do real. A escrita que visa à teoria, que conduz a um certo tipo de saber, diz respeito ao objeto da ciência. Em nossas leituras observamos que Lacan não recusa a ciência, ao contrário, para ele a ciência é condição da psicanálise.

Lacan imagina a borda do Real como um lugar de escrita, uma escrita correlativa- fortemente correlativa- à escrita do saber científico, a escrita da ciência que decifra e aloca numa escrita matemática as estruturas do universo. Isso tem uma importância fundamental: Lacan consegue pensar a nuances e os detalhes da escrita psicanalítica somente através da proposição de uma forte correlação com a escrita científica, uma correlação na qual a forma do saber da ciência mostra-se como a chave fundamental que permite compreender a forma do saber inconsciente, ao mesmo tempo em que o sujeito do saber inconsciente acaba revelando-se como condição de possibilidade, foracluída, rejeitada do saber científico. A partir da proposição dessa relação Lacan explora os pontos de convergência e de divergência entre a letra científica e a letra psicanalítica, e realiza essa exploração precisamente como um incessante movimento de "superação", isto é, de reconhecimento de que o próprio impasse é condição positiva de superação, de avanço, de invenção teórica. $\mathrm{O}$ impasse de escrita lógico-matemática anuncia a dimensão do Real, por exemplo, quando Lacan postula o princípio de contradição lógica como a condição de possibilidade da noção de verdade psicanalítica. (Milán-Ramos, 2007, p. 25, grifos do autor)

Quando o autor afirma que "o sujeito do saber inconsciente se revela como condição de possibilidade", podemos dizer que a escrita em psicanálise se ocupa do enunciado e da enunciação. O enunciado estaria mais próximo do nosso capítulo entre Benjamin e Freud, pois estaria ali o sujeito social, submetido ao processo secundário do recalque. Na enunciação temos um sujeito inconsciente e recalcado.

Os fenômenos inconscientes existem na distância entre enunciado e enunciação, distância que escapa aos esforços enunciativos definicionais: quando pretendemos enunciar alguma coisa sobre o inconsciente, ele se constitui em ato em outro lugar, 
escapando ao enunciado. Quer dizer, as formações do inconsciente são fenômenos radicalmente não-tautológicos, que respondem ao mecanismo da repetição inconsciente, caracterizado pela impossibilidade, encarnada em Das Ding, de retorno ao mesmo. Nesse sentido, a tautologia, o nível do enunciado, são representações fracassadas de Das Ding. (Milán-Ramos, 2008, p. 51)

Assim, a escrita do sujeito em psicanálise, quando se trata da escrita de uma experiência analítica, diz respeito a um sujeito situado historicamente que leva a sério seu saber inconsciente, ocupando-se dele. O relato de uma análise é o relato de alguém que se deixa levar pelos conteúdos de enunciação, ou seja, pelo saber inconsciente. Em relação à escrita testemunhal, de sobreviventes, a diferença entre os relatos e os testemunhos de experiências traumáticas históricas - como o holocausto, a ditadura ou a escravidão - é que, nesses últimos, não houve possibilidade de se interrogar sobre o que aconteceu. E se o saber é limitado no nível da ação, a ausência de qualquer tipo de sentido, o real aleatório, impossibilita ainda mais uma ação do sujeito em direção ao enfrentamento do real. Este é o problema do trauma nos casos das narrativas de testemunho ao qual retornaremos posteriormente.

Retomando os esforços enunciativos definicionais da citação anterior, a palavra experiência ocupa um papel interessante nesse meio, porque também pertence a um contexto científico. Pode-se dizer que a experiência, se fosse definida em contexto científico, apareceria como experiência laboratorial, como experimento controlado e observável, capaz de estabelecer uma relação entre variáveis e constantes de uma série de fatos que buscam elaborar uma verdade transmissível ou repetível por qualquer outro que se atenha às mesmas condições controladas de observação. Em Aristóteles a experiência diz respeito à técnica.

Ora, em psicanálise, nossas condições controladas de observação aludem a uma situação claramente definida em que o paciente nos apresenta um sofrimento, um malestar e um sintoma. Temos aí a passagem da noção de experiência, o estatuto de saber que ela implica, entretanto, direcionado ao discurso analítico. Há uma referência na "Direção da cura e princípios de seu poder" que nos parece importante: "É claro que nossa física não passa de uma fabricação mental, da qual o símbolo matemático é o instrumento. Pois a ciência experimental não é tanto definida pela quantidade aplicada à realidade quanto pela medida que introduz no real" (Lacan, 1966, p. 286, grifo nosso). Lacan estava tão advertido da teoria freudiana, para o tratamento do mal-estar, do 
sofrimento e do sintoma, ele incluiria as dimensões eu-mundo, biológica: atividade/passividade e econômica (prazer/desprazer).

Porque funciona na borda, na distância que a linguagem proporciona, a borda do real consiste num atravessamento, onde a localização entre dois espaços é o que nos importa. A escrita teórica é o que estamos fazendo nesta tese; a escrita de mediação é o que se faz, para tratar da experiência, tratar o real pelo simbólico, no recurso aos poetas e à literatura. Mas o interessante, é que, quando se teoriza, também se faz uma mediação. E essa mediação é a subjetivação não poética do conceito. É como se o conceito tivesse uma face na teoria e outra na mediação.

De igual modo, se voltando-me contra a nostalgia que ela serve, a arma da metonímia, eu me recuso a buscar qualquer sentido para-além da tautologia, e se, em nome de "guerra é guerra" e de "um vintém é um vintém", decido-me a ser tão somente aquilo que sou, como desvincular-me, aqui, da evidência de que sou nesse ato mesmo? Tanto quanto, ao me deslocar para o polo oposto, metafórico, da busca significante, e ao me devotar a tornar-me o que sou, a vir a sê-lo, não posso duvidar de que, mesmo ao me perder nisso, é aí que estou. (Lacan, 1957, p. 521, grifo nosso)

\subsection{Escrita transformadora: a força subjetiva do conceito}

Ainda que uma escrita se diga científica e com potência de transmissão teórica, ela tem efeitos subjetivantes para quem o faz, ou seja, o pesquisador sofre as consequências de sua escrita no ato de teorizar. A escrita teórica é também uma escrita que mediadora, transforma a mão de quem escreve, parafraseando Levi. ${ }^{8}$

Há, com certeza, muita coisa ultrapassada. Eu tenho total consciência de que me desloco sempre ao mesmo tempo em relação às coisas as quais me interesso e em relação ao que já pensei. Nunca penso totalmente a mesma coisa porque meus livros são para mim experiência, num sentido que eu gostaria que fosse o mais pleno possível. Uma experiência é algo do qual a pessoa sai transformada. Se eu tivesse que escrever um livro para comunicar o que já penso antes de ter começado a escrever eu não teria nunca coragem de fazê-lo. Não escrevo porque eu não sei ainda exatamente o que pensar desta coisa que eu tanto gostaria de pensar. De forma que o livro me transforma e transforma o que eu penso. Cada livro transforma o que eu pensava quando terminava o livro precedente. Eu sou um experimentador e não um teórico. Chamo teórico aquele

\footnotetext{
${ }^{8}$ Trata-se de um conto de Primo Levi, chamado o retorno de Lorenzo, em que ele afirma que o amigo ainda vivo, se transformou em personagem: "a tarefa de transformar uma pessoa viva numa personagem bloqueia a mão de quem escreve". Levi, 386.
} 
que constrói um sistema geral seja de dedução, seja de análise, e aplica de maneira uniforme a campos diferentes. Não é meu caso. Sou um experimentador e nesse sentido o que eu escrevo para mudar a mim mesmo e não mais pensar a mesma coisa que antes. (Foucault, [1978/1980], 2001, pp. 860-861, grifo nosso, tradução nossa.)

Nos pareceu clara a noção de experiência sucedânea à experiência de escrita e é a partir da sua relação com o saber que é possível que isso se dê. Essa escrita diz respeito também à escrita de um saber. Ora, a escrita de uma experiência de análise é então uma escrita mista, em que o autor se coloca como testemunha de uma experiência - aquela da qual saiu transformado -; e uma escrita que pretende transmitir como se deu a construção desse saber de transformação. E o mais importante, no caso de Foucault, é que ele teoriza; influenciado pelas leituras de Bataille, flexibiliza o conceito, e faz com que seu saber caminhe. Na mesma entrevista com Trombadori, afirma: "A relação com a experiência deve, no livro, permitir uma transformação, uma metamorfose, que não seja simplesmente a minha, mas que possa ter um certo valor, um certo caráter acessível para os autores, que essa experiência possa ser feita pelos outros" (Foucault, [1978/1980]2001, p. 865, grifo nosso, tradução nossa).

Aqui Foucault aproxima o caráter transformativo do caráter de transmissibilidade de uma experiência, por, como afirmamos na nossa introdução, na citação acerca do otimismo. Nesse momento, a parte daquela citação que precisamos destacar é: “...penso que há mil coisas a fazer, a inventar, a forjar por aqueles que, reconhecendo as relações de poder nas quais estão implicados, tenham decidido resistir a elas ou delas escapar". O que vemos aqui é o teórico suscitando uma ação, corroborando a ideia de Benjamin de que a catástrofe é que as coisas continuem como estão. Desse modo, esses depoimentos de Foucault, nos revelam como o saber é finito em relação à ação, teorica e clinicamente. Não é na ética da psicanálise que Lacan afirma que a psicanálise acompanha o paciente até o limite extático do "tu és isto"?

Observamos o movimento transformativo de escrita também na citação a seguir, quando Milán-Ramos escreve sua experiência com o ensino e estilo de Lacan:

Não havia trânsito, não acontecia aquele nível de compreensão e apreensão do significado do texto -aquilo ao qual eu estava acostumado. As palavras pareciam funcionar de outro modo. Isso, é claro, produz uma tensão subjetiva, traz desconfortoperplexidade, angústia. É um momento pleno em mi(s)tificações, cheio de fantasmas, de compromissos...O corpo fica comprometido nesse mal-estar, e isso se prolonga, isso 
dura. Trata-se de uma forma de gozo- gozo na linguagem, gozo no sentido: o texto lacaniano interroga o desejo, e o sujeito responde como pode. (Milán-Ramos, 2007, p. 17, grifo nosso)

E mais adiante o autor observa, ainda sobre o estilo de Lacan: "Mudou o golpe da palavra, o tempo da frase, o lugar da certeza? Uma experiência de subjetivação terá acontecido" (idem, p. 20).

Observemos como o autor fala em primeira pessoa na citação a seguir:

O livro Passar pelo escrito é o efeito de minha aproximação à experiência de linguagem que Lacan propõe no seu ensino: aproximei-me para ser testemunha dessa experiência, e a partir dos elementos que foram mais significativos... poder mostra-la, aproximar o leitor, ser efêmera testemunha de sua aposta. Que o leitor se aproxime da experiência, que se exponha, que fique à intempérie, e, se possível, que "passe" por ela, que faça dela uma experiência subjetivante. (Idem, p. 30)

Em relação ao que estamos chamando de escrita da mediação, seu valor é bastante interessante na transmissão, pois evita a redução da teoria psicanalítica a um quadro puramente conceitual.

Teríamos vários modos de nos aproximarmos da escrita em psicanálise, mas um dos quais escolhemos é a ligação entre a escrita e o real. Na medida em que "o real é o limite de nossa experiência" (Lacan, 1956/1957, Staferla, p. 32), essa escrita diz respeito também à escrita de um saber.

Quando trabalhamos a experiência em A interpretação dos sonhos, declaramos como Freud escreveu acerca dos sonhos a partir de uma escrita de si. Foi a partir dos próprios sonhos que Freud começou a teorizá-los. A escrita de si pode percorrer vários caminhos, como mostraremos no próximo capítulo - na escrita das experiências de perda em Ralf Waldo Emerson, Barthes e Beckett. Isso coloca uma questão importante em nossa pesquisa, porque demonstra a natureza híbrida entre os discursos da psicanálise, a filosofia e a literatura:

Frente à banalidade da língua comum, a linguagem poética permite a ultrapassagem do lado imediato, na medida que incita significações novas, inauditas para o falante. Neste sentido, a poesia cria então usos da língua não previstos nem pela sintaxe lógica da linguagem, nem mesmo por sua gramática. Viola o código linguístico e se recusa a limitar um único sentido à sua "mensagem": ela exige do leitor a sua participação. (Iannini, 2013, p. 262) 
A seguir discutiremos o que destacamos na citação acerca da participação do leitor na obra, mas uma advertência é preciso ser feita em relação à experiência sensível desta tese. "Não se trata aqui de fazer um elogio cego de um vitalismo romanticista vazio e sem conceito, fundado sobre a primazia das paixões, mas de uma constatação da distância que separa duas maneiras de experimentar a letra e o real: aquela da ciência, aquela da arte" (Iannini, 2013, p. 260). O que chamamos de experiência sensível é o estatuto híbrido, heurístico do trabalho com a escrita de experiências e a fecundidade dessas leituras para um trabalho teórico. E adiantando um pouco o tom do nosso último capítulo: "O estilo científico raramente lança mão de metáforas. Em compensação, especialmente na fase inicial, quando se lança numa nova área de pesquisas, o cientista não hesita em deixar-se guiar por analogias" (Perelman apud Iannini, 2013, p. 261).

Para Barthes a oposição entre ciência e literatura diz respeito ao modo como cada uma utiliza a linguagem. Na ciência, segundo o autor, a "linguagem quer se tornar tão neutra quanto possível" (Barthes, 2004, p.4); e na literatura, o poético ("designa esse tipo de mensagem que toma sua própria forma por objeto, e não seus conteúdos." (idem, p. 5)

Em nossa introdução, ao anunciar o modo como iniciamos a atividade de pesquisa começaram a germinar, mencionamos o caso do pequeno Hans, na leitura que fizemos do pós-escrito de Freud. E assim queremos destacar o que Freud situou naquele momento como algo que escreveu, e depois escreveu novamente. Não foi reescrever, e sim escrever sobre o que o havia surpreendido depois de ter escrito sobre o tratamento de Hans.

Se nosso interesse como pesquisadores surgiu a partir de um texto lido, tomamos de imediato a experiência de que, para uma escrita que se pretenda investigativa, a moção epistemofílica iniciou-se por uma leitura. Um texto lido, que depois passou a ser investigado e que culminou numa nova escrita. Processo que enlaça o singular de uma leitura com o universal da teoria. Para tanto, vamos recorrer brevemente a uma metáfora que nos pareceu interessante para discutir esse aspecto da captura do leitor por um tema até a sua transformação em escrita compondo a mediação teórica. Utilizaremos o que Philippe Willemart chamou de "roda da leitura". São cinco os movimentos dessa roda, cujo movimento e ideia de processo nos interessa. 
O primeiro movimento do leitor, a escolha de um texto, o desejo de saber (leitura do pós-escrito de Hans), que Willemard situa como: "reivindicar algo que está separado de nós, mas nos pertence, e do qual se trata do que nos completa" (Lacan apud Willemart, 2014, p. 22). O segundo movimento da roda é o do leitor que mergulha no texto: "lemos exercendo a pulsão escópica, não apenas desejando mas nos fazendo personagens" (Willemart,2014,p.22). O terceiro movimento, a pausa ou leitura em voz alta, consequências ainda do mergulho do leitor no movimento dois. O quarto movimento diz respeito à pressa do leitor que quer logo saber o que aconteceu.

No nosso caso, não houve pressa, já que não lemos o caso Hans como um romance. Entretanto, nosso espanto e captura pelo tema da memória e do esquecimento foi imediato quando soubemos, pelo pós-escrito de Freud, que Hans não se lembrava em nada de sua experiência - a não ser pelo nome da cidade Gmunden. Diante disso, no exercício de investigação da experiência de Hans, nos interrogamos: Como foi possível esquecer? E porque nos interrogamos, escrevemos.

O quinto e último da roda da leitura é a decisão do leitor de continuar ou abandonar o livro. E o que dessa roda da leitura ou do tipo de escrita se coordena com o real que temos enfatizado? "Escrever, (ler), é ouvir a voz perdida. É primeiro achar a chave do enigma, de preparar a resposta. É procurar a linguagem na linguagem perdida" (Quinard, 2009 apud Willemart, 2014, p. 24).

A fala em primeira pessoa, o relato de análise, não é autobiográfica. Vale lembrar como para a psicanálise a verdade tem estrutura de ficção. A ficcionalidade biográfica e testemunhal onde a escrita alcança seus efeitos.

Precisamos declarar o que estamos chamando de narrativa: "um processo transformativo que é reconhecido num âmbito da linguagem intermediário entre o discurso e a fala, o trabalho de linguagem que contorna um objeto, conferindo-lhe uma estrutura de ficção" (Dunker, 2015, p. 219).

Se o sintoma é um fragmento da liberdade perdida (Dunker, 2015, p. 32) e uma palavra amordaçada (Lacan), para Freud, as obras dos escritores imaginativos permitiram a ele um ganho teórico acerca da histeria: "com o emprego de algumas fórmulas psicológicas, obter pelo menos alguma espécie de compreensão sobre o curso dessa afecção" (Freud, 1893-1895/1988, p. 172). 


\section{3 Experiências de perda}

No primeiro capítulo procuramos nos deter na intricada relação entre o trauma e a experiência analítica no que concerne a perda de objeto, ou seja, a relação entre o real, o trauma e a experiência de perda. No segundo, trabalhamos as condições de escrita na psicanálise. Se salientamos que os principais textos de Freud concernentes ao trauma e ao luto foram escritos no contexto da guerra, assim como as referências em Walter Benjamin que virão posteriormente em nossa pesquisa, neste capítulo, reunindo experiências de escrita relativas ao luto, estamos preparando o terreno conceitual que irá ter seu destino no capítulo seguinte, entre os filósofos que teorizam a noção de experiência a partir de perdas.

Nesse momento, mostramos o luto como a elaboração de uma experiência de perda, destacando a escrita como ponto central dessa operação psíquica. Para tanto, recorremos a textos de autores que escreveram sobre suas experiências de perda e demonstramos que, na tentativa de recuperação de uma experiência, o que acontece é o surgimento de uma nova experiência. A escrita é mediadora entre o sujeito e o objeto num destino, numa memória, numa ausência.

Como o que foi perdido não pode ser reencontrado, o objeto amado deixa apenas rastros, e assim podemos inserir em nossa pesquisa uma outra versão do objeto $a$ ainda não trabalhada por nós: o objeto amado como causa de desejo. Vejamos como, no seminário da angústia, Lacan escreve sobre este objeto: "Este $a$, objeto de identificação, para sublinhar com uma referência nos próprios pontos que se sobressaem da obra de Freud, é essencialmente a identificação que está no princípio do luto, por exemplo" (Lacan, 1963, Staferla, 23 de janeiro)

Tomamos como texto de base, para a apresentação e articulação dessas experiências, o texto Luto e melancolia de Freud. O fator desencadeante da perda culmina no que pode vir a ser um quadro sintomático, num mundo que se torna empobrecido e vazio para o enlutado. No espaço da relação com o outro, entre as perdas reais e as ideais, se constrói o que Foucault (1981-1982) chamou de cuidado de si. A relação do sujeito com suas perdas modula o cuidado de si, que tem como pressuposto: 
antes de conhecer-se a si mesmo, ou de cuidar do outro, é necessário cuidar de si mesmo, expressão que trataremos com minúcia mais a frente.

Sobre a escrita dessas experiências de perda, é importante destacar como os melancólicos são os que talvez façam as perguntas mais interessantes acerca da existência, pois questionam o tempo todo o sentido da vida.

Por que razão todos os que foram homens de exceção, no que concerne à filosofia, à ciência do Estado, à poesia ou às artes, são manifestadamente melancólicos, e alguns a ponto de serem tomados por males dos quais a bile negra é a origem, como contam, entre os relatos relativos aos heróis, os que são consagrados a Hércules? (Aristóteles, apud Peres, 2013,

Na citação anterior vemos a genialidade e a melancolia presente na Antiguidade. A melancolia na teoria dos humores na Idade Média era regida por Saturno:

Saturno surge como o astro que governa o melancólico, astro das contradições, da inteligência e da contemplação, da apatia e do êxtase, da renúncia e do sacrifício, representa as experiências de separação desde o corte do cordão umbilical até o supremo despojamento do velho. (Chevalier \& Alain Gheerbrant, 1986 apud Peres, p. 103, grifo nosso)

O sujeito sempre será interrogado pelo enigma da morte, e a escrita da experiência de perda também diz respeito a um destino estético para tais experiências, numa vida que vale a pena ser contada.

Daí surge o impulso para o nascimento do gênero biográfico e autobiográfico. Uma vida que sirva ao mesmo tempo de exemplo e que inclua em si a própria atividade de narrá-la. Isso é tributário do cultivo, principalmente entre os estoicos, da escrita de si. (Dunker, 2011, p. 221).

Há uma outra consideração importante que precisa ser feita sobre nossas referências nesse capítulo. Não discutiremos o diagnóstico clínico dos autores, por mais que a observação sobre o trabalho de luto dos mesmos nos aproxime dessa questão. Procuramos tirar proveito da grande interrogação da existência que têm esses filósofos para demonstrar o potencial de criação das experiências de escrita. 


\section{Ralph Waldo Emerson:}

Ralph Waldo Emerson tinha Montaigne como ídolo. Para ambos, "a morte diz respeito ao limite da experiência, mesmo que não se trate da morte própria, senão a do ser amado" (Jay, 2009, p. 320, grifo nosso). Transcendentalista, o filósofo era também escritor e poeta. Nasceu em Boston, em 1803, e aos setenta e oito anos morre deixando dois grandes ensaios - ambos acerca da experiência de perda - que influenciaram sobremaneira a William James, o filósofo do pragmatismo que apresentaremos no próximo capítulo. O primeiro dos ensaios foi "Círculos", datado de 1841; o segundo, de 1844, intitulou-se "Experiência". O evento autobiográfico percebido no primeiro ensaio foi a morte de sua primeira mulher, Ellen, em 1831. Esse primeiro evento o convocou vários temas como a natureza do esquecimento e a superação do passado.

Nesses ensaios houve um momento pivô que marcou uma diferença em seus escritos filosóficos: trata-se de quando não foi capaz de reagir como havia reagido à morte de Ellen. Ao contrário, ele adota outra radical atitude, e não mais acredita no poder de esquecimento, como veremos posteriormente. ${ }^{9}$

$\mathrm{Na}$ primeira série de ensaios é possível observar uma atitude positiva de Emerson em seguir adiante. Ele utiliza a metáfora de círculos em relação à vida, à continuidade, ao movimento, e escreve a importância de lidar com os sofrimentos: “A nossa vida é um aprendizado sobre a verdade de que, ao redor de cada círculo, outro círculo pode ser desenhado; de que não existe fim na natureza, mas que todo fim é um começo." Como também: "A vida do homem é um círculo que se autodesenvolve; círculo este que, a partir de um anel imperceptivelmente pequeno, expande-se rapidamente em todos as direções, para fora, para novos e maiores círculos, infinitamente". Nesse momento, Emerson acreditava que a vida era como era, as pessoas morrem, novos relacionamentos começam, a melhor maneira de viver é tentar se acomodar às mudanças da vida ao invés de tentar procurar um entendimento para os eventos. Estabelecer defesas contra as dores das experiências seria o mesmo que ceder a elas: "parece-me que, com cada precaução que uma pessoa toma contra esse mal, essa mesma pessoa se subjuga ao poder do mal”.

\footnotetext{
${ }^{9}$ Todos os fragmentos dos textos de Emerson foram retirados do site <americanphilosofers.com> e traduzidos por nós.
} 
Na natureza cada momento é novo; o passado é tragado e esquecido, o que está por vir é sagrado. Nada é seguro, somente a vida, a transição, o espírito revigorante...As pessoas desejam ficar em uma situação confortável; somente quando não estão em situação confortável há esperança para elas. A vida é uma sucessão de surpresas". (Emerson, grifo nosso)

Na citação anterior é interessante observar como a eminência de uma situação devastadora coloca a existência concebida em termos do destino. Essa acepção de destino é bastante importante para a temática da experiência em torno do real.

Por conta desse "poder" Emerson é capaz de esquecer. Contrariando o que afirmamos acerca das elaborações no capítulo anterior - quando tomamos a palavra utilizada por Mezan: “inquecer" —, seu objetivo não parece fazer trabalhar as lembranças para que elas se tornem eficazes simbolicamente. Em relação à morte de Ellen, sua primeira mulher, esses escritos indicam uma superação daquela perda, quando afirma: "O que buscamos com desejo incessante é esquecermos de nós mesmos, sermos surpreendidos fora da nossa zona de conforto.... a vida se dá de forma maravilhosa; ela ocorre por desamparo".

Pode-se perceber, entretanto, que toda a ênfase no esquecimento dada por Emerson não significa que ele o tenha alcançado. E a vida parecia oferecer-lhe motivos para que ele não se esquecesse. Quando nasceu a primeira filha do seu segundo casamento, a mãe da criança deu à ela o nome da ex-mulher de Emerson, morta anos antes. Emerson insistiu para que outro nome lhe fosse dado, mas a mãe da criança decide sem volta que sua filha se chamaria Ellen. Retornaremos a essa questão de nomeação posteriormente, mas aqui já podemos observar como a perda incide sobre um certo tipo de quadro sintomático, um objeto em substituição a outro, trazendo uma problemática da nomeação em psicanálise - tal como acontece com o caso Aimée de Lacan.

Somente o fato de se dedicar à escrita desses eventos seria suficiente para supor que o escritor não tinha poder em relação às suas recordações. Mas o fracasso quanto ao poder da própria memória é admitido e percebido em seus escritos quando, em 1842, acontece outra tragédia em sua vida: a morte de seu filho, aos cinco anos, vítima de escarlatina. A partir daí seus escritos tomam outra direção, e nesse momento se dedica ao ensaio intitulado Experiência. "Não entendo nada desse fato, a não ser sua amargura. 
Não tenho explicações, não há consolo que surja do fato em si; somente distração, esquecimento e a busca por novos objetos". Há um paradoxo para Emerson, então, já que, se a morte anteriormente o fizera forte, a morte do filho Waldo torna-se agora puramente sem sentido. Se antes ele tratava a morte como cura da própria dor, ele não pode ser curado da dor da ausência de Waldo. É como se dois lutos consecutivos reforçassem ainda mais a força do a posteriori.

Entendo esse esvaecimento e essa lubricidade de todos os objetos, que faz com que eles escorram por nossos dedos quando o agarramos com mais força, como a parte menos bonita da nossa condição. A natureza não gosta de ser observada, e gosta que sejamos seus joguetes e parceiros de jogo...Ela nunca nos deu poder para darmos golpes certeiros; todas as nossas pancadas são de relance, todos os nossos acertos são acidentes. (Emerson)

Emerson, inconsolável, escreve que as teorias filosóficas não ajudam. Afirma que "a natureza odeia calculadoras". As palavras de William James, ${ }^{10}$ como que tentando consolar o amigo, dizem: "A experiência, como a conhecemos, tem maneiras de se impor, fazendo com que corrijamos as nossas fórmulas presentes". O que nos convoca a uma observação, a do sofrimento como transformação.

Sobre a busca de entendimento sobre o que lhe aconteceu, Emerson escreveu: "O segredo do mundo é o nó entre a pessoa e o evento". Dois anos depois da morte de Waldo, ele afirma: “o mundo pode não ser compreensível, nós podemos não ser capazes de lidar com a tragédia e o sofrimento, mas nós ainda temos que agir".

Aos setenta e oito anos, morre depois de escrever: "A minha Morte subserviente, por meio de um ritual que traz consigo a solução, / Derrama o finito no infinito" deixando um enigma a seus sucessores sobre a natureza da experiência de perda. Com tudo isso que soubemos de Emerson poderíamos nos perguntar em nossa pesquisa: houve uma experiência de luto nesses escritos? O que houve na segunda perda do filósofo que o fez rever toda a sua teoria? Seria a perda do filho ainda criança a causadora de uma dor irrecuperável? Seria a infância, por excelência, o espaço da experiência?

${ }^{10}<$ americanphilosofers.com 


\section{Roland Barthes}

Quando solicitaram a Barthes que definisse sua identidade, afirmou: "O que faço dentro de mim é filosofar, refletir em minha experiência" (Barthes apud Jay) Barthes, 2009, p. 437). No dia seguinte à morte de sua mãe, Barthes começou um "Diário de luto", de 26 de outubro de 1977 a 15 de setembro de 1979. No prefácio da edição brasileira do Diário de luto (2011), o leitor encontra um comentário acerca da elaboração desses escritos, de forma contextualizada em relação a outros textos do autor, indicando como importantes textos de sua obra foram escritos sob o signo da morte de sua mãe. Em 1978 escreveu A preparação do romance e, entre abril e junho de 1979, A câmara clara. Nesse período preparou também o seu curso do Collège de France sobre $O$ neutro. Estariam os tradutores sugerindo que o autor produziu muito nesse período, ou, numa outra forma de dizer, fez de seu luto um motor de sua escrita? Tal como foi em Freud? Quando os tempos não pareciam propícios para um trabalho de criação, Freud escreveu sua metapsicologia. A teoria psicanalítica é contemporânea a duas guerras mundiais.

Outra pergunta possível: por que a escrita sobre o luto da morte da mãe de Barthes precisou ser feita sob a forma de um diário? Se tentássemos responder a essas questões estaríamos nos excedendo nas motivações do nosso texto. Entretanto, são perguntas importantes para fazer valer a importância dos escritos de Barthes em relação à sua própria experiência e de como o modo de narrar diz respeito a um trabalho elaborativo. Desse modo, destacamos algumas notas de seu diário. Depois que atravessou a primeira noite sem sua mãe, ele escreveu: Dia 26 de outubro: "Primeira noite de núpcias. Mas primeira noite de luto? (Barthes, 1977/2011, p. 3). E no dia seguinte:

“- Você não conheceu o corpo da Mulher! - Conheci o corpo de minha mãe doente, depois agonizante. (Idem, p. 4). No dia 29 de outubro, escreveu sobre a medida do luto: "(Larousse, Memento): dezoito meses para o luto de um pai, de uma mãe" (idem, p. 19). Dia 30 de novembro: "Não dizer Luto. É psicanalítico demais. Não estou de luto. Estou triste” (idem, p. 71, grifo do autor). 
A rotina de Barthes - marcada pela ausência da mãe, pelas lembranças dos seus cuidados com ela doente - , a dificuldade de sair ao mundo novamente, o paradoxo de se sentir livre, mobilizam Barthes para a construção de uma narrativa que, embora seja descontínua, pela indeterminação dos descaminhos das suas lembranças, apresenta-se de forma cronológica e organizada nos dias. Não houve um só dia durante esse período que Barthes não tivesse escrito em seu diário, houve dias que escreveu mais de uma vez, em páginas diferentes. Ocupava uma página por dia, um sentimento por página.

Barthes escreveu várias definições de luto. É interessante observar como, desde o primeiro dia, o autor recorreu a essa palavra. No dia 27 de outubro: "todos calculam - eu o sinto - o grau de intensidade do luto. Mas é impossível (sinais irrisórios, contraditórios) medir quanto alguém está atingido" (Barthes, 1979/2011, p. 10). Essa passagem não parece ser bem próxima a de Emerson quando afirmou que a "natureza detesta calculadoras"? Outra definição aparece adiante, no mês de dezembro: "Luto: mal-estar, situação sem chantagem possível”. (Barthes, 1977, p. 78)

Acerca da relação entre o luto e a sua própria escrita, Barthes, no dia 29 de outubro, declara um certo funcionamento:

Ideia - assombrosa, mas não desoladora - de que ela não foi "tudo" para mim. Senão, eu não teria escrito uma obra. Desde que eu cuidava dela, há seis meses, efetivamente ela era "tudo" para mim, e esqueci completamente que havia escrito. Eu estava perdidamente por conta dela. Antes, ela se fazia transparente por conta dela. Antes, ela se fazia transparente para que eu pudesse escrever. (Barthes, 1977, p. 16)

Ainda sobre sua escrita, afirma mais adiante: "Não quero falar disso por medo de fazer literatura - ou sem estar certo de que não o será - embora, de fato, $a$ literatura se origine dessas verdades" (Barthes, 1977, p. 23).

Sobre o quão adoecedor pode ser o luto, afirma: "Uma parte de mim vela no desespero; e, simultaneamente, outra se agita arrumando mentalmente os mais fúteis de meus assuntos. Experimento isso como uma doença” (idem, p. 25). Dias antes havia escrito: “(...) Irritação. Não, o luto (a depressão) é bem diferente de uma doença. De que desejam curar-me? Para encontrar que estado, que vida? Se há trabalho, aquele que nascer dele não será um ser comum, mas um ser moral, um sujeito do valor - e não da integração". 
Mais adiante, reúne, numa página de seu dia, a experiência de escrever e a possibilidade de adoecer:

Sei agora de onde pode vir a Depressão: relendo meu diário no último verão, sinto-me ao mesmo tempo "encantado" (tomado) e decepcionado: portanto, a escrita em seu máximo é afinal irrisória. A Depressão virá quando, do fundo da tristeza, não poderei me agarrar nem mesmo à escrita. (Barthes, 1979/2011, p. 60)

No dia 11 de novembro define solidão: "não ter ninguém em casa a quem dizer: voltarei a tantas horas, ou a quem poder telefonar (dizer): pronto, cheguei” (Barthes, 1979/2011, p. 42). Quando define tristeza, porém, o tradutor da edição brasileira adverte o leitor que, naquele momento, Barthes utilizou outra palavra que ainda não havia aparecido, mas que ainda apareceria várias vezes no diário. Trata-se de "chagrin", que, sem equivalente na língua portuguesa, foi traduzida por 'tristeza', 'desgosto' ou 'pesar'.

O aspecto relacional do luto aparece no dia 18 de novembro: "Não manifestar o luto (ou pelo menos ser indiferente a isso), mas impor o direito público à relação amorosa que ele implica" (idem, p. 53, grifo do autor); mais adiante afirma: "Todo casal (conjugal) forma um bloco do qual o ser solitário está excluído”. Em 21 de novembro, noite: "entedio-me em toda parte" (idem, p. 61, grifo nosso).

Nos parece interessante o quão desorganizador é tentar relacionar os dias de Barthes de acordo com as definições, referências e palavras. É um texto interrompido pelos dias; entretanto, de uma contiguidade impressionante, como se aproximasse a metáfora da metonímia. É um texto sem texto, contínuo e descontínuo ao mesmo tempo: “Assusta-me absolutamente o caráter descontínuo do luto” (Barthes, 1977/2011, p. 65).

Sobre a dificuldade de se abrir ao mundo e a novos objetos: "Tudo me fere. Um nada desperta em mim o abandono. Suporto mal os outros. Atraído por uma decisão de retirada para longe dos outros (não suporto mais o universo Y)” (Barthes, 1978, p. 84).

M. e eu sentimos que, paradoxalmente (já que de hábito se diz: Trabalhe, distraia-se, veja pessoas), é quando somos empurrados, ocupados, solicitados, exteriorizados, que sentimos a maior tristeza. A interioridade, a calma, a solidão, a tornam menos dolorosa. (idem, p. 97) Como o amor, o luto torna o mundo, o mundano, irreal, inoportuno. Resisto ao mundo, sofro com o que ele me pede, com sua demanda. O mundo aumenta minha tristeza, minha secura, meu desassossego, minha irritação. O mundo me deprime. (Barthes, 1977/2011, p. 123, grifo nosso) 
Podemos inferir uma gramática da perda nas palavras: solidão, depressão, tristeza, tédio, irritação que se repetem. Mas vale lembrar que são essas as mesmas palavras que escutamos em nossos consultórios, mesmo que não haja um luto (real) envolvido. Como interpretar, sem jogar o sujeito na angústia? Esse parece ser um desafio clínico diário, pois, mesmo dentre aqueles que não vivem o luto de uma perda real, há os que, sempre tristes e deprimidos, sucumbem a qualquer tipo de curto circuito no vínculo com o outro. O sujeito moderno parece estar vinculado a um trabalho de luto sem perda (real) e tenta se recuperar das perdas sem o trabalho requerido por ela simbolicamente. Todo luto diz respeito a uma perda, mas nem toda perda precisa do trabalho de um luto. Essa medida, essa fronteira, é o desafio do clínico atualmente.

\section{Samuel Beckett: Primeiro amor}

Narrado em primeira pessoa, o livro é acerca de uma experiência de perda: “Associo, com ou sem razão, o meu casamento à morte do meu pai, em outros tempos. Talvez existam outras ligações, em outros planos, entre esses dois acontecimentos, é possível. Já me é difícil dizer o que julgo saber" (Becket, 1970/2014, grifo nosso).

A personagem afirma não ter confiança na memória de datas e que, certa vez, teve que voltar ao cemitério onde seu pai estava enterrado para ver a data do enterro e do nascimento dele e, então, fazer o cálculo de com qual idade havia morrido. "Anotei essas duas datas limite num pedaço de papel, que trago comigo. É assim que posso afirmar que eu devia ter mais ou menos vinte e cinco anos na época do meu casamento." São dois esquecimentos concomitantes: o da idade que tinha quando se casou e o da idade que o pai tinha quando morreu. Sua certeza era somente quanto à data de seu próprio nascimento e quanto à idade de seu falecimento; sentia-se à vontade em cemitérios, onde lhe agradava a leitura das inscrições:

...vagueio, com as mãos às costas, entre as lajes, as eretas, as chatas, as inclinadas, escolhendo as inscrições. Elas nunca me decepcionaram, as inscrições, há sempre três ou quatro tão engraçadas que preciso me agarrar à cruz, ou à estela, ou ao anjo, para não cair. A minha já compus há muito tempo e continuo satisfeito com ela, bastante satisfeito. Meus outros escritos mal têm tempo de secar e já me dão asco, mas meu epitáfio ainda me agrada. Ele ilustra uma lição de gramática. Infelizmente há poucas chances de que chegue a se erguer sobre a cabeça que o aconteceu, a menos que o Estado se encarregue do assunto. Mas para poder me exumar, será preciso primeiro 
me encontrar, e receio que o Estado tenha tanta dificuldade em me encontrar morto quanto vivo. É por isso que me apresso em registrá-lo aqui, antes que seja tarde demais:

Aqui jaz quem daqui tanto escapou

Que só agora não escape mais ${ }^{11}$

Sem querer fazer uma interpretação do texto, é suficiente observar como os escritos para o personagem ocupam um lugar de resíduo, resto, dejeto, secam como os cadáveres e dão mais asco que estes: "O cheiro dos cadáveres, que sinto nitidamente sob o cheiro de relva e do humo, não me desagrada (...)Por mais que se lavem, os vivos, por mais que se perfumem, eles fedem". (Beckett) A lição de gramática dos epitáfios expressa o limite e a finitude.

O leitor, na segunda página de Primeiro amor, percebe que a relação da personagem com a morte é peculiar. Associa a morte do pai ao seu casamento e também ao momento em que conheceu seu primeiro amor. Este momento foi concomitante a uma dificuldade que teve em saber onde viveria depois da morte do pai, quando fora obrigado a sair de casa - pois o seu pai era o único que o queria lá. "Um dia, voltando do banheiro, encontrei a porta do meu quarto trancada e minhas coisas empilhadas diante da porta" (Beckett). E como estes escritos ocupam o lugar da escrita de uma recordação, há um momento em que titubeia e diz: “As coisas devem ter se passado de modo completamente diverso, mas que importa, a maneira como as coisas se passam, desde que se passem? (Beckett)

Mas para passar agora a um assunto mais alegre, o nome da mulher a quem me uni, pouco tempo depois, o apelido era Lulu. Pelo menos é o que ela me dizia, e não vejo que interesse ela podia ter em mentir a esse respeito. Evidentemente, nunca se sabe. Ela também me contou seu sobrenome, mas esqueci. Eu devia ter anotado, num pedaço de papel, não gosto de esquecer os nomes próprios. (Beckett)

Vemos a dúvida acerca da memória em outro momento de dor para a personagem:

Quando ela terminou, e meu próprio eu, o domesticado, foi reconstituído pelo auxílio de uma breve inconsciência, encontrei-me só. Às vezes me pergunto se tudo isso

\footnotetext{
${ }^{11}$ Todas as citações de Beckett são do livro: Primeiro amor. A editora brasileira optou por uma edição sem paginação. A versão original foi publicada em 1970 em Paris.
} 
não é invenção, se na realidade as coisas se passaram de modo completamente diverso, segundo um esquema que precisei esquecer. (Beckett)

Quando ela terminou, entretanto, ele disse a ela que viesse de vez em quando. E entre dias sim e dias não, eles se encontravam no mesmo banco, à margem do canal que atravessava a cidade, onde ela lhe dissera seu nome e sobrenome - mas ele havia se esquecido. Na ausência dela, sentia sua falta e, farto do nome Lulu, lhe deu outro: Anne.

Fiquei portanto agradavelmente surpreso ao ouvi-la dizer que tinha um quarto, muito agradavelmente surpreso. Eu suspeitava disso aliás. Quem não tem o seu próprio quarto? Ah, ouço o clamor. Tenho os dois quartos disse ela. Quantos quartos você tem exatamente? Disse eu. Tenho dois quartos e uma cozinha. (Beckett)

Anne, que havia sido Lulu, pede a ele que busque suas coisas. Ele disse que não havia nada. Aos poucos ele foi se acostumando naquela casa. Ela aparecia de vez em quando para ver se ele precisava de alguma coisa e se estava bem. E, nesse momento, o leitor de Beckett se dá conta de qual luto se tratava; de que Lulu ou Anna não estavam apenas com ele, como se a invenção de outro nome para ela tivesse intuído isso.

O que me incomodava mais eram outros ruídos, risinhos e gemidos abafados, que enchiam o apartamento em certas horas, tanto de dia quanto à noite. Eu não pensava mais em Anne, nem um pouco, mas tinha assim mesmo a necessidade de silêncio, para viver a minha vida. Por mais que eu raciocinasse, me dissesse que o ar é feito para transportar o barulho do mundo, incluindo inevitavelmente risos e gemidos, aquilo não deixava de me afetar...Levei muito tempo, a vida toda por assim dizer, para compreender que a cor de um olho entrevisto ou a origem de algum ruído distante estão mais perto da Giudecca, no inferno das ignorâncias, do que a existência de Deus, ou a gênese do protoplasma, ou nossa própria existência, e exigem mais da sabedoria, que fique longe. (Beckett)

A personagem aproxima a experiência traumática a um sem saber, a um "não sabendo já sabia", à aparente inocência, à ignorância que recobriam a mulher idealizada. A morte desse ideal, encontra seu ápice: "Eu podia obviamente ter me levantado e olhado pelo buraco da fechadura, supondo que ele não estivesse tampado, mas o que se pode ver por esses buracos? Então você vive da prostituição? disse eu. Nós vivemos da prostituição, ela respondeu." (Beckett) 
Esperamos que o nosso leitor tenha tido o efeito surpresa que Beckett coloca em seu livro. A morte real, que surge no cadáver, nos cemitérios, era mais confortável que a dor do luto de seu ideal de mulher. No entanto, a ele ainda reage:

Você não pode pedir que eles façam menos barulho? Disse eu, como se acreditasse no que ela acabava de dizer. Acrescentei, Ou outro tipo de barulho? Eles não podem deixar de ganir, disse ela. Serei obrigado a ir embora, disse eu. Ela encontrou algumas tapeçarias em suas tralhas de família e pendurou-as em nossas portas, a minha e a dela. Perguntei se não seria possível, de vez em quando, comer uma pastinaca. (Beckett)

Retomando o que anunciamos no início do capítulo: A relação do sujeito com suas perdas modula o cuidado de si. Se a escrita, no aspecto elaborativo, pode ser pensada também num modo do cuidado de si, é pela via do relato, pela narrativa, que chagamos à acepção de verdade que nos interessa:

No cuidado de si, trata-se mais de uma prova pela qual se ingressa voluntariamente e que não visa a verdade em sua generalidade e totalidade, muito menos a indulgência do outro, mas a exploração da capacidade de dizer a verdade sobre si, de tornar-se sujeito de uma verdade. Aqui encontramos uma terceira acepção de verdade, que não é nem aletheia nem emunah, antes examinadas. A veritas corresponde à verdade como justo dizer - dizer preciso, que procede do verum, ou seja, um relato exato, sem omissões e narrado com integridade. Assim como aletheia liga-se ao presente e a emunah, ao futuro, a veritas liga-se ao passado e à narração. Daí sua ligação com a dimensão do testemunho. (Dunker, 2011 p. 215, grifo nosso)

A experiência sensível, mediadora entre a experiência de perda e a perda de experiência necessita de uma noção de verdade que corresponda a um passado e à narração, tal como a citação acima procura demonstrar.

“O segredo do mundo é o nó entre a pessoa e o evento”, (Ralfh Waldo Emerson)

"Não quero falar disso por medo de fazer literatura - ou sem estar certo de que não o será -, embora, de fato, a literatura se origine dessas verdades". (Barthes)

"As coisas devem ter se passado de modo completamente diverso, mas que importa, a maneira como as coisas se passam, desde que se passem?" (Beckett) 
Retiramos três modos de escrever sobre a experiência de perda. Uns sofrem mais; outros, menos. Observemos mais duas formas discursivas de luto. Há, depois do evento, uma decisão do sujeito, uma ação que coloca sua posição em relação à contingência, a uma vida colocada sob termos de destino. Na consolação de uma mãe que tinha perdido seu filho, Sêneca apresentou à mesma dois tipos de discursos de duas outras mães que também haviam perdido seus filhos:

...narra-se a atitude de Octavia, que eu perder o filho Marcelo permanece toda a vida no mesmo estado do dia do funeral. Rejeita seu outro filho, traja luto e passa o resto de sua existência devotada à memória cristalizada do filho perdido. Lívia, em semelhante situação age de forma inversa. Parece enterrar seu filho Drusos e ao esmo tempo o sofrimento de sua perda. Ela jamais deixou de pronunciar o nome do filho perdido e convive pública e privadamente com sua memória. Vê-se assim como Sêneca parece antecipar a diferença entre o luto patológico e a melancolia (Octavia) do luto suposto normal (Lívia) (Silva apud Dunker, 2011, p. 231, grifo nosso)

A partir da apresentação de duas modalidades discursivas de luto, Sêneca indica que há uma decisão do sujeito depois do evento traumático; uma ação que estabelece sua posição em relação à contingência.

Um jovem de dezesseis anos deixa a sua cidade no interior e vai para capital estudar o curso dos seus sonhos. Quando perguntado acerca da dificuldade dessa experiência, sozinho e sem dinheiro, respondeu: "Eu me acostumei à realidade (eu a assumi, como se fosse a doença de alguém que se ama.” (Bosco, 2010, p. 123) Este exemplo é interessante para pensar como a realidade faz com que a economia pulsional negocie. O jovem não nega o princípio de realidade, ao contrário, se posiciona diante dela. A realidade é o que o protege do real. A natureza irredutível do real abre a uma angustia metonímica, pois, por mais avassalador que seja, o real não pode ser alcançado. O real é aquele encontro marcado com o destino, mas que sempre adia esse acontecimento. A tentativa de Octavia era a de alguém que quer escapar da realidade, buscando o encontro com o real. Livia, ao contrário, quer escapar de fora para dentro da realidade. O jovem deste parágrafo é Pedro Almodóvar, para quem "a realidade é uma imperfeição incurável que nos obriga primordialmente a amá-la" (Bosco, 2010, p. 123).

Para concluir este capítulo, é importante observar que o modo como se posiciona em relação ao real é uma questão política, ética e direciona uma clínica. Esperamos ter cumprido com nosso objetivo do capítulo, apresentando várias modalidades discursivas 
de luto e demonstrando que, ao escrever sobre a experiência de luto o que acontece é o surgimento de uma nova experiência. Vale lembrar que esse trabalho elaborativo que a escrita proporciona independe de uma experiência analítica. O sentido da vida precisa ser permanentemente reconstruído. Mas nem sempre é possível. Nas tentativas das palavras a algo significar, a literatura, a poesia são também depositárias da dor existencial. Em Freud, morte e desilusão são os dois temas que o acompanham: "A morte esvazia o mundo, a desilusão e a tristeza abatem-se sobre o eu (ego) e, do mesmo modo, o esvaziam. Seguem juntos luto e melancolia, e o sentimento de vazio ganha espaço, exerce sua dominação, tornando o homem mais consciente de sua solidão" (Peres, 2011, p. 111).

A solidão será tratada por nós no capítulo "Sofrimento decorrente da experiência de perda", onde nos caberá retomar uma pergunta que fizemos na introdução: O homem moderno estaria mais sujeito a perdas e lutos? 


\section{Capítulo 3. Da experiência de perda à perda da experiência}

Acreditamos que Cantos de experiência, publicado por Martin Jay em 2005, seja o livro mais completo sobre o termo experiência, onde o autor se dedicou a apresentar e compreender por que "tantos pensadores de tantas diferentes tradições se sentiram compelidos a ocupar-se deste problemático termo" (Jay, 2009, p. 15, tradução nossa). Desse modo, acabamos por retirar de Walter Benjamin o centro de gravidade acerca da perda de experiência do sujeito moderno. O problemático termo "experiência" é também trabalhado em outras vertentes da filosofia. Neste capítulo discutiremos duas dessas, com o que Jay intitulou: "reconstituição pós-estruturalista da experiência" (Bataille, Barthes e Foucault) e o "pragmatismo clássico norte-americano" (James, Dewey e Rorty).

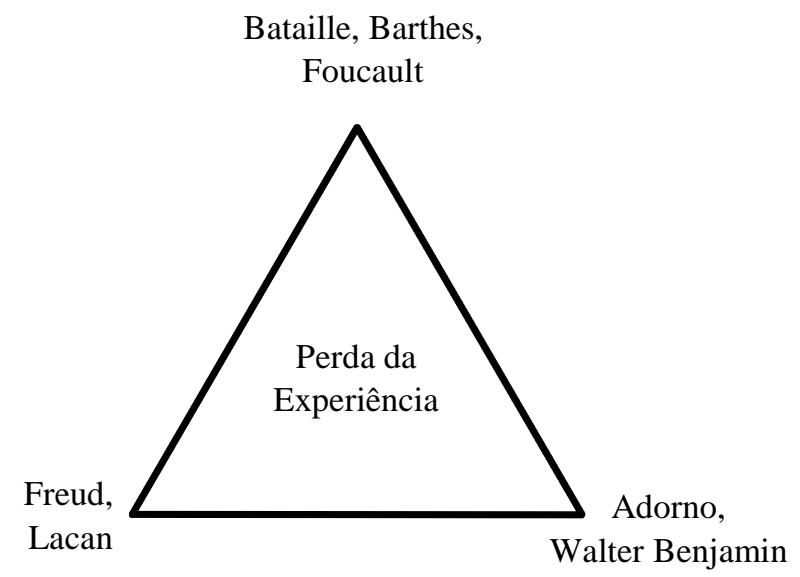

Através de uma apresentação esquemática e comentada, mostramos como as aproximações da psicanálise e da filosofia se deram. Depois, discutiremos cada uma delas.

Correspondeu a pensadores do século XX como Walter Benjamin, Martin Heidegger, Theodor Adorno, Georges Bataille, Michel Foucault e Roland Barthes, a tarefa de resolver as implicações do ideal paradoxal do sujeito da experiência sem um sujeito em relação com a desdiferenciação (Entdifferenzierung) com as esferas de valor. Talvez a expressão filosófica mais importante dessa busca não apareceu entretanto na Europa do século XX, e sim com um movimento impreciso que chegou a ser denominado pragmatismo. (Jay, 2005/2009, p. 313, grifo nosso). 
Nos vértices, colocamos os autores que foram pesquisados e observamos que na interseção entre eles está uma preocupação comum: a perda de experiência. Como afirmamos na introdução, Freud e Lacan, herdeiros das luzes, se ocuparam da perda de experiência do sujeito moderno. Por isso é possível pensar, por exemplo, como o diagnóstico social de Freud e de Benjamin são convergentes.

No Brasil, há um grande investimento nas leituras destes autores, mas é sobre Benjamin e Adorno que recaem a maior parte das discussões acerca da perda da experiência. Nossas leituras aproximaram os autores em torno da noção. No terceiro capítulo, por exemplo, mostramos como Barthes se ocupou do que procuramos de denominar: experiência sensível, com escrita acerca do luto de sua mãe.

Trabalhamos com estes autores da filosofia e da psicanálise através das experiências de perda. Afirmamos que a experiência de perda de Ralf Waldo Emerson influenciou William James. Acreditamos que essa é uma maneira de aproximar teoricamente o Real à filosofia. Com isso, pensamos em como a psicanálise e filosofia habitam o campo discursivo que diz respeito ao Real.

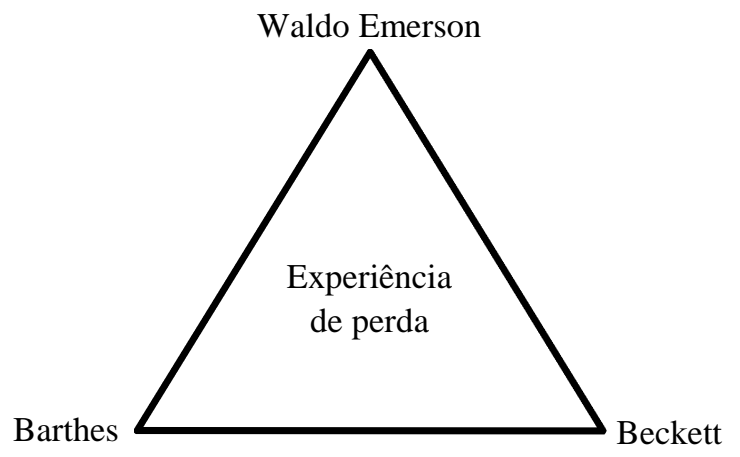

Nos vértices do triângulo acima colocamos os autores que escreveram sobre suas experiências de perda - três escritas distintas sobre o luto. No segundo triângulo estão nos vértices os mesmos autores do primeiro, juntamente a Freud e Lacan. Mostramos, no primeiro capítulo, a perda relacionada ao objeto, ao real, negativizando a estrutura das coisas; e, em Lacan, como aquele que condensou as variedades da experiência de perda no conceito de objeto a. 
Apresentamos, no capítulo anterior, como Barthes e Emerson (que influenciou James) se apropriaram da experiência sensível, para a escrita da experiência de perda. Neste capítulo Barthes retorna como filósofo, ou seja, seus escritos surgem agora no campo discursivo da filosofia. Neste autor, percebe-se uma falta de integração, onde o eu aparece como perdido, disperso, esparso e esporádico. Estas características procuram esclarecer que o eu desorganizado e desintegrado resiste a uma reconstrução narrativa coerente.

Destacando a importância de Barthes ao tratar a experiência, marca-se uma diferença importante e autêntica; pois se, segundo Benjamin, o sujeito moderno perde sua capacidade de narrar, para Barthes, a tentativa do recobrimento da perda se dá utilizando a força da mesma perda para se reconstruir, se circunscrever. Em Barthes há uma apropriação da ideia de perda para a composição da sua escrita. Como isto se mostra em Barthes? Se a narrativa de Barthes perde em coesão, seu estilo, entretanto, reflete uma coerência astuta onde a perda compõe a possibilidade de experiência.

Barthes é influenciado pela erótica de G. Bataille, erótica que traz um impacto importante na acepção de experiência, que não pode ser mais aquela ingênua, dessexualizada - ou seja, a experiência que era compreendida como uma forma cristã de salvação baseada na inocência.

A próxima citação é um exemplo da resistência de Barthes em compor uma narrativa coerente, assim como traz a marca da erótica herança de Bataille. Trata-se da descrição de seu costume de ir ao cinema, como descreve no Rumor da língua:

Como se tivesse dois corpos ao mesmo tempo: um corpo narcisista que vê, perdido no espelho devorador, e um corpo perverso, disposto a fetichizar não a imagem senão o que a excede: a textura do som, a escuridão, a massa indiscernível dos outros corpos, os eixes de luz, a entrada na sala, o vestíbulo que se abandona, em suma, a fim de distanciar-me de despegar-me, complico uma relação por uma situação. (Jay, 2009 apud Barthes, 1987)

A massa indiscernível de corpos, a desconfiada capacidade de penetração de significado, esse momento de pathos caracterizam a experiência que, segundo Bataille: "não procede de uma revelação, onde tampouco se revela nada, para não dizer o desconhecido, é o fato de que nunca anuncia algo tranquilizador" (Bataille apud Jay, 2009, p. 429, grifo nosso). Esta era essência de Experiência interior, livro escrito 
durante toda a vida de Bataille. Sua versão mais elaborada surgiu em meados de sua carreira, durante a Segunda Guerra Mundial e a ocupação da França, momento em que já havia abandonado suas tentativas de devolver o perdido encantamento à sociedade moderna. Os resultados foram evidentes no primeiro tomo de sua obra de três volumes que culminou em Experiência interior.

Por experiência interior entendo o que habitualmente se chama experiência mística: os estados de êxtase, rapto ou ao menos de imediata emoção. Mas não estou pensando aqui na experiência confessional, a qual temos que aderir até agora, senão uma experiência desnudada, livre de laços, inclusive de uma origem, de qualquer confissão, seja qual for. Por esta razão, não me agrada a palavra mística. (Jay, 2009, p. 429 , apud Bataille, grifo nosso.)

É importante a atenção em relação à experiência mística que desagrada Bataille. Experiência mística no campo discursivo da negatividade, da impossibilidade, tal como estamos baseando nossa tese, diz respeito ao não todo, colocando o gozo místico nas fronteiras da razão, no limite do inominável.

A "experiência livre de laços", "inclusive de uma origem", a experiência interior de Bataille inspirou Barthes numa poética de transgressão. Barthes nunca elogiou a "experiência interior", mas tampouco pediu licença para utilizar a palavra 'experiência' em sua obra. A autenticidade de seu erotismo alcança seu ápice naquilo que denominou de cruising, que significa a busca de companheiros sexuais em lugares públicos. "As artimanhas se repetem. O sujeito se submete a uma rotina. A repetição é uma forma ambivalente; às vezes denota fracasso, impotência; outras podem interpretar-se como uma aspiração" (Jay, 2009, p. 439).

Parece haver em Barthes uma habilidade em relação à experiência de perda, o que talvez possa ser observado na citação a seguir:

Praticamente não existe em Roland Barthes esse amargo lamento pela suposta perda ou degradação da experiência genuína que vemos nos escritos dos outros críticos culturais do século XX, como Raymond Williams na Inglaterra, Theodor Adorno na Alemanha e Estados Unidos. (Jay, 2009, p. 442, grifo nosso)

Tal habilidade parece vir por "sustentar a possibilidade da experiência sem um sujeito forte e centrado" (Jay, 2009, p. 441). O que podemos formular através dessas 
discussões é que, por ser mais habilidoso em relação à experiência de perda, não necessita lamentar amargamente a perda da experiência.

Esta resistência à nostalgia não significava, por certo, que Barthes aderira a um conceito utópico de experiência...Suas próprias reflexões sobre as implicações da mortalidade demonstram amplamente este ponto. De fato Barthes se ocupou da questão da morte e de seu lugar na experiência humana tanto como Bataille. (Jay, 2009, p. 442, grifo nosso.)

O que significaria, portanto, "se ocupar" da morte? Em Câmara clara, Barthes não coloca as fotografias a serviço da memória. Diante da experiência desconcertante de se confrontar com a fotografia de sua mãe quando esta tinha cinco anos, o autor teve uma experiência crucial que assim descreveu: "a experimentei tão fortemente como havia sido, tão forte que era minha Lei interior. A qual era uma maneira de resolver a morte." (Barthes apud Jay, p.442)

Quando apresentamos o Diário de luto escrito por Barthes, notamos que o autor escreveu Câmera clara na mesma época, ou seja, a escrita sobre fotografias já estava sob o signo da morte da mãe. Temos assim um paradoxo, pois no diário escrevia sobre sua dor num trabalho que ele mesmo denominou de luto. Em Câmera clara afirmou ter "resolvido a morte". "A fotografia é adialética: constitui um teatro desnaturalizado onde a morte não pode ser contemplada, meditada ou interiorizada" (Barthes apud Jay, p. 442).

Aparentemente a relação de Barthes com a morte parece ter ocupado um espaço distinto entre os autores que se debruçaram sobre a experiência. A influência da erótica de Bataille na experiência interior parece ser uma das causas disto. Assim, retomando nosso interesse de investigar a noção de experiência em outros campos discursivos, podemos afirmar, tal como foi trabalhado no terceiro capítulo, que diante da morte há uma atitude, uma ação para a vida. Dessa decisão o sujeito modula sua relação com os objetos. O real mais próximo do sujeito parece mesmo estar no estilo, no efeito da experiência. Num texto recente publicado no Brasil sobre uma exposição das aquarelas de Barthes, Rodrigo Fontanari afirmou sobre as experimentações plásticas do autor "não 
resultam totalmente numa ausência de forma, mas numa forma de ausência". ${ }^{12}$ O que dá à ausência um estatuto de forma só pode ter tido boa familiaridade com o real.

Antes de concluir essa contribuição de Barthes acerca da experiência, precisamos deixar claro que não estamos supondo que, para os outros críticos culturais, a noção de experiência seja usada equivocadamente. É justamente na busca de uma noção de experiência na filosofia que seja empática com a psicanálise, e com a noção de real, que buscamos alguma possibilidade de acepção da experiência que compreenda um sujeito passível de ser transformado. Nem tão forte que não possa ser transformado, nem tão fraco que não possa ser autêntico.

No esquema seguinte, vemos nos vértices Bataille, Barthes e Foucault — sendo este último também colocado em nossos desenvolvimentos anteriores, no capítulo sobre a escrita, como aquele que tem como a acepção de experiência a ideia de transformação. Retomando sua definição de experiência, "é algo do qual saímos transformados" - qualidade que interessa ao sujeito psicanalítico —, o sujeito que escreve sobre a experiência restituidora e, portanto, transformadora que é uma experiência de análise. É importante lembrar ao leitor como Jay localiza esses autores: situados na "reconstituição pós-estruturalista da experiência". Foucault entra aqui em nosso debate não somente pelo caráter transformativo da experiência, mas também por sua ligação com a experiência interior de Bataille — relação que tentaremos apresentar de forma breve, mas que corresponda aos nossos propósitos.

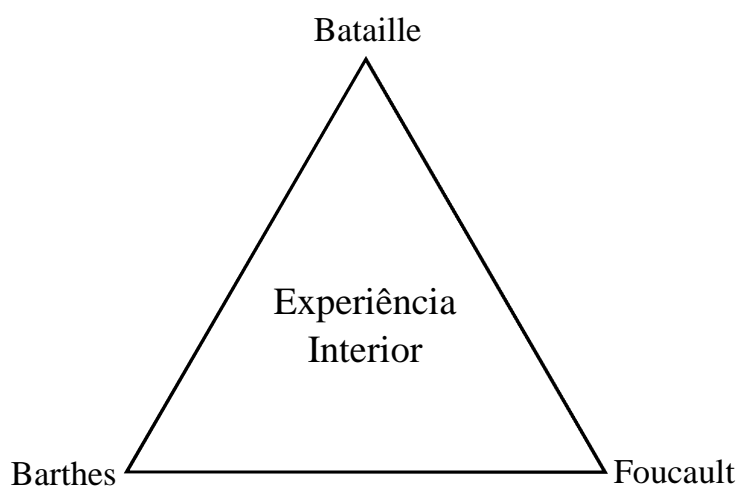

Para definir a experiência interior, Foucault faz um percurso que a citação seguinte parece demonstrar:

\footnotetext{
${ }^{12}$ Blog da editora Martins Fontes: wmfeditora.com.br/blog: Sobre as aquarelas de Barthes.
} 
Ao negarmos o limite do Ilimitado, a Morte de Deus conduz a uma experiência em que nada pode voltar a enunciar a exterioridade do ser, e, por conseguinte, a uma experiência que é interior e soberana. Mas uma experiência desta índole, para qual a morte de Deus é uma realidade explosiva, revela seu próprio segredo e clarificação, sua finitude intrínseca, o reino ilimitado do Limite e a vacuidade daqueles excessos em que se esgota e onde a encontra deficiente. Neste sentido a experiência interior é o impossível (sendo o impossível tanto aquilo que experimentamos quanto aquilo que constitui a experiência). (Foucault, apud Jay, p. 445)

Assim, a experiência interior, como o próprio nome indica, diz respeito a um corte com a exterioridade soberana, limitando o Deus ilimitado. É uma existência que inclui a negatividade quando afirma ser impossível.

Não pretendemos esgotar o que Foucault denominou experiência durante toda a sua obra. Precisaríamos, para isso, nos debruçar com mais vagar nessa temática no percurso do autor. Entretanto, pudemos constatar que o interesse sobre a experiência em seus últimos textos, passa a ser um tema mais explícito: O Uso dos prazeres e o segundo volume da História da sexualidade (1984) — cujos títulos fazem lembrar a influência erótica de Bataille. O que é importante ressaltar para nossos propósitos é que o autor, ao final de sua escrita, se dizia transformado pela experiência de seus livros e por isso se considerava um experimentador, e não um teórico. Afirma terem sido Nietzsche, Blanchot e Bataille os autores que permitiram que ele se libertasse daqueles que dominaram sua formação universitária. Vejamos como a negatividade da experiência surge novamente em torno da impossibilidade, quando foi convidado a diferenciar a experiência desses autores para os fenomenólogos:

A experiência do fenomenólogo consiste, basicamente, em uma maneira de organizar a percepção consciente de qualquer aspecto da vivência cotidiana em sua forma transitória, a fim de captar o seu significado. Para Nietzsche, Bataille e Blanchot, ao contrário, a experiência é tentativa de alcançar este momento da vida que se acha o mais próximo possível da impossibilidade de viver, o qual se encontra no limite ou no extremo. Tentam reunir, ao mesmo tempo, a máxima quantidade de intensidade e impossibilidade. (Foucault, 1978/1980, p. 862, grifo nosso, tradução nossa). 


\section{O pragmatismo clássico americano:}

Em busca de uma noção de experiência na filosofia que inclua o real em seu campo discursivo, discutimos e apresentamos a experiência com os pós-estruturalistas: Barthes, Bataille e Foucault. Destes, retivemos a ideia de um sujeito passível de ser transformado. Estes autores pertencem à uma discursividade onde há espaço para o equívoco, o inominável, e o impossível. Assim, em uma numa gramática afetada pelos efeitos do real, vamos buscar essa ressonância naqueles que também valorizaram a noção de experiência no pragmatismo norte-americano.

É importante deixar claro ao leitor que a aproximação ao pragmatismo vem em decorrência do valor que demos à escrita de um luto (Emerson) e de essa escrita ter influenciado William James — trata-se do testemunho de um sujeito atravessando a filosofia.

\section{O pragmatismo}

O pragmatismo é um movimento filosófico que surgiu na virada do século XIX ao XX e que se compõe de diversos autores. Para apresentar o locus do pragmatismo na filosofia, escolhemos uma citação do precursor do movimento pragmatista, no texto intitulado $O$ pragmatismo.

Em princípio, pelo menos, [o pragmatismo] não visa resultados particulares. Não tem dogmas ou doutrinas, salvo seu método. Como o jovem pragmatista italiano Papini disse muito bem, situa-se no meio de nossas teorias, como um corredor em um hotel. Inúmeros quartos dão pra ele. Em um, pode-se encontrar um homem escrevendo um volume ateístico, no próximo, alguém rezando por fé e força; em um terceiro, um químico investigando as propriedades de um corpo. Em um quarto, um sistema da metafísica idealística está sendo excogitado; em um quinto a impossibilidade da metafísica está sendo demonstrada. Todos, porém, abrem para o corredor e todos devem passar pelo mesmo se quiserem ter um meio prático de entrar e sair de seus respectivos aposentos. (William James, 1907/1979, p. 21, grifo nosso)

Da citação anterior, o que nas primeiras frases parece ser a formulação de uma contradição, saberes e verdades tão distantes num mesmo lugar, acabam por encontrar 
os mesmos meios de circulação se quiserem um jeito prático de entrar e sair. Parece-nos uma boa metáfora para a aproximação discursiva do campo da psicanálise e da filosofia para o estudo da noção de experiência, que pertence a essa variação, a essa ideia utilitária que o corredor de James descreve. Além disso, a citação que abre este capítulo havia situado o pragmatismo entre os demais pensadores do século $\mathrm{XX}$; para os pragmatistas, a primeira característica apresentada foi como 'movimento impreciso' tal como o corredor de James procura metaforizar.

Entretanto, os múltiplos caminhos possíveis para o estudo da noção de experiência para os pragmatistas necessitam de algumas coordenadas. É necessário destacar o que não se altera para os pragmatistas ao longo do tempo, já que nossa primeira aproximação desses filósofos diz respeito a uma certa liberdade teórica. Essa observação se faz necessária tendo em vista um cuidado com a aproximação desse tipo de leitura. Vale destacar, assim, que o que marca a originalidade do movimento é que "não há rejeição da metafísica, ou ao menos de uma forma desta. De diferentes modos eles apontavam para uma ontologia mutável, inacabada, empírica e finita" (Bezerra, 2008, p. 9). Quanto ao seu método, ele visaria a extrair as "regras de conduta" como consequência das modificações na experiência trazidas pelos teóricos, como as metafísicas e religiosas. Quanto à abordagem da verdade, os pragmatistas demonstramse diferentes em vários questionamentos como: "se as verdades são relações imutáveis e eternas, que interesse pessoal poderia despertar no homem?" (Bezerra, idem, p. 10).

Ora, a alternância de verdades, que o plural da citação anterior destaca, se relacionará diretamente com a experiência; o sujeito sofre o efeito de uma experiência e a verdade não se apoiará na identidade, e sim na sua utilidade.

Não cabendo mais à verdade julgar a relação entre o fenômeno e uma "coisa em si”, esta passaria a ser dada na comparação entre duas experiências, uma anterior e outra posterior a uma determinada atividade. Verdade não é mais a relação entre um pensamento e seu antecedente, mas com seu consequente. E, no caso, o valor dessa relação entre uma experiência e sua consequente não deve ser baseado em uma identidade, mas em outros critérios. E estes são fornecidos pelo operacionalismo, pelo utilitarismo e pelo darwinismo. Desse modo, o valor de verdade não se encontra mais na identidade, mas na solução de problemas, na promoção de utilidade ou na satisfação funcional, opção que varia de acordo com cada pragmatismo. (Bezerra, 2008, p. 11, grifo nosso) 
$\mathrm{O}$ destaque que demos na citação anterior marca um antes e um depois, uma consequência, o que nos remete ao que no capítulo das experiências de perda apresentamos como ineficiência do saber, ou como o fato de que o saber é finito em relação à ação.

\section{$O$ culto da experiência no pragmatismo}

William James deu um nome à sua noção de experiência: experiência pura. Essa noção de experiência é decorrente de uma insatisfação do filósofo com as formalizações. Desse modo, James converteu deliberadamente o vago numa virtude (Jay, 2005/2009, p. 322, grifo nosso). As formalizações para o autor são insatisfatórias devido à insuficiência da linguagem para capturar a realidade que procurava compreender. A sua nomeação para experiência é, portanto, metafórica, e se baseia no presente - mais precisamente "no campo instantâneo do presente". Esta imediatez é expressa na experiência dos recém-nascidos — o que nos abre a oportunidade de retomar o estudo da perda do objeto que foi desenvolvida no primeiro capítulo. Por ora, vale ressaltar o que afirma James: "A experiência pura é o nome que dou ao fluxo original da vida antes que a reflexão o tenha categorizado. Somente os recém-nascidos têm experiência pura no sentido literal" (James apud Jay, p. 328, grifo nosso).

A noção de experiência utilizada por James diz respeito a algo suprimido ou perdido no mundo moderno, mas também no homem a partir de seu nascimento. Para o autor, há uma porção do humano que, no início da vida, está ainda inalterada pela modernidade. As operações linguísticas são as que acompanham a perda que a modernidade impôs; entretanto, os recém-nascidos ainda não sofreram essa supressão. Seriam aqueles momentos em que os bebês sonham, mas não sabemos com o quê? Talvez uma pergunta que não se cala para a psicanálise seja esta: com o que sonham os recém-nascidos, já que não possuem o aparato linguístico necessário para compor os elementos da vida onírica? Seria a voz da mãe o suficiente para a matriz desses elementos? Observemos com mais cautela a questão para James:

As primeiras investigações psicológicas de James identificavam a experiência com a imersão pré-reflexiva no fluxo com a vida. Esta era a experiência entendida como Erlebnis, a qual foi cada vez mais marginalizada por- ou submetida a operações 
linguísticas e conceituais que inevitavelmente acompanharam a nossa caída na cultura (uma caída que ainda não sofreram os recém nascidos e que se supera momentaneamente graças aos estupores induzidos pelas drogas, o sonho, os golpes na cabeça, etc. (Jay, 2005/2009, p. 328, grifo nosso, tradução nossa)

Vale retomar o que discutimos no primeiro capítulo sobre a experiência de satisfação no Projeto (1895). Naquele momento havíamos destacado como a experiência aparecia também em A interpretação dos sonhos (1900) tomando, em ambos os casos, a amamentação como paradigmática. No entanto, salientamos como o tradutor do texto optou por preservar a palavra vivência, ainda que ao lado da palavra experiência (Erlebnis e Erfahrung, respectivamente), do seguinte modo: "a experiência da vivência de satisfação". E aqui nos cabe destacar que é sob o signo da natureza que William James invoca a experiência pura. A Erlebnis, segundo o autor, estaria mais próxima à natureza, anterior à entrada na cultura que se dá através de operações linguísticas. Por isso a imediatez da experiência pura, pois não é possível definir quando se dá a queda na cultura. Aparentemente a experiência pura se assemelha à noção de desamparo (Hilflosigkeit), no que diz respeito à inconsistência biológica. Entretanto, pela sua imediatez, não poderá ser definida como desamparo — porque o desamparo psíquico pode vir a retornar. O sujeito se transformará em um curto espaço de tempo, já que é recém-nascido, e está sob as leis do "campo instantâneo do presente". Um sujeito na radicalidade do limiar de sua transformação. A experiência pura, tal como é nomeada para James, e sua relação com o bebê recém-nascido, nos convida a um debate entre a noção de experiência e a linguagem. É um momento paradoxal, pois se, por um lado, o recém-nascido não dispõe de um aparato linguístico, ele não perde em experiência, ao contrário - a experiência pura pela qual passa prevê uma futura apropriação linguística da experiência.

Há mais dois aspectos da experiência em James que se fazem necessários explicitar: a influência da religiosidade na sua teoria e o ponto nevrálgico de sua noção de experiência e que nos trouxe até o pragmatismo: sua relação com Ralph Waldo Emerson, cujo testemunho foi trabalhado no capítulo anterior desta tese. Ambos compartilhavam as mesmas inquietações sobre o filosofar sistemático: "Emerson, considerado com frequência um protopragmatista, desconfiava, como James, do sensacionalismo empirista e do intelectualismo abstrato, e preferia a intensidade emocional e a prática do filosofar sistemático" (Jay, 2009, p. 319, grifo nosso). Havia 
em Emerson também um intenso sentimento de perda ou afastamento da natureza. Desassossegado depois da perda do filho, afirma ter escrito em busca do que denominou “impulso universal de crer numa razão para seguir adiante.” Este autor

Foi um dos primeiros a permitir aos norte-americanos em acreditar que eram distintos de seus antepassados europeus, mais propensos a pensar metafisicamente, em seu célebre ditado de que "toda alma engenhosa que aspira a elevar-se deixa a doutrina atrás de si e se guia por sua própria experiência’. (Jay, 2009, p. 319)

O que apresentamos como testemunho de Emerson no capítulo anterior ganha um outro valor agora; ou, como afirmamos anteriormente: trata-se do testemunho de um sujeito atravessando a filosofia. Outra forma de dizer é como a experiência de perda ocupa um tecido teórico na filosofia. Vejamos a observação de Martin Jay acerca da diferença entre o luto para Emerson e para Freud:

Da morte advém o limite da experiência, ainda que não se trate da própria morte, senão a de um ser amado. Se há um trabalho de luto em seu ensaio, não é obviamente, o tipo postulado por Freud em quanto uma elaboração frutífera e uma reintegração do objeto perdido, senão, algo mais lábil e frágil, talvez mais parecido com a repetição melancólica que com desanudar as expectaticas suscitadas pelo objeto faltante. (Jay, 2009, p. 320, grifo nosso.)

Essa diferença entre a escrita elaborativa e a escrita de Emerson nos faz formular a seguinte pergunta: a escrita que não tem efeitos de luto deixa de tratar o real? Independentemente da resposta, que não intencionamos responder, a escrita de Emerson, suposto melancólico, não deixa de ocupar um lugar importante na investigação da noção de experiência. Esse tipo de escrita tem valor enquanto imprime uma negatividade no discurso da filosofia. O real nem sempre está a serviço de uma simbolização. Em seu ensaio afirma: "Que pena que minha dor não pôde ensinar-me nada(...) Nada nos resta, salvo a morte" (Emerson apud Jay, 2009, p.320) - vemos que nem sempre o real está a serviço da simbolização e que nem sempre o sofrimento está a serviço do saber.

Assim, conclui-se e completa-se o que iniciamos no terceiro capítulo, quando debatemos três lutos distintos:

Uma parte das características da melancolia é tomada de empréstimo ao luto e outra parte do processo de regressão da escolha narcísica de objeto ao narcisismo. Por 
um lado, como o luto, ela é a reação à perda real do objeto de amor, mas além disso está comprometida com uma condição que falta ao luto normal ou que, quando ocorre, o converte em luto patológico. A perda do objeto de amor é uma oportunidade extraordinária para que entre em vigor e venha à luz a ambivalência das relações amorosas. (Freud, 1914/2011, p. 65, grifo nosso.)

Se Emerson diz que "esperamos a morte com uma lúgubre satisfação, dizendonos que ao menos se trata de uma realidade que não nos iludirá", podemos pensar qual a importância da escrita para aquele que tem esta familiaridade com o real.

...não é difícil descobrir uma analogia essencial entre o trabalho da melancolia e o do luto. Assim como o luto leva o ego a renunciar ao objeto, declarando-o morto e oferecendo-lhe como prêmio permanecer vivo, também cada uma das batalhas de ambivalência afrouxa a fixação da libido ao objeto, desvalorizando-o, rebaixando-o, como que também matando-o. (Freud, 1914/2011, p. 83)

Talvez um dos caminhos para se pensar um luto que não aconteceu passe pela citação que se segue:

Emerson sofre não somente pela perda do filho, senão também por sua incapacidade de sentir essa dor de uma maneira plena, pela brecha infranqueável entre a expectativa e a realização. Como resultado disso "a dor passa a ser um tropo da experiência, porque a relação do eu com esta, como a sua própria relação com a dor, é oblíqua, angular, contingente, dissociada...Uma vez que o eu compreende sua relação com a experiência, o que compreende é algo que foi eliminado. A morte é a fonte dessa compreensão ao mostrarmos nossa relação com cada outro evento". (Jay, p. 320, grifo nosso)

Por mais que sejam inconclusos os questionamentos sobre os efeitos da escrita depois de uma experiência de perda, o que podemos afirmar que é exatamente essa a dificuldade clínica do tratamento da dor da perda. O trabalho clínico procura interferir na configuração das relações de objeto. Por isso ele reconstitui e é um sucedâneo da experiência- o sujeito, numa análise, acaba por criar uma nova experiência. 


\section{A transformação de Foucault, a imediatez de James e de Bataille e o pathos de Barthes:}

Destaquemos estes aspectos em cada um dos autores que trabalhamos até aqui: a transformação, a imediatez e o pathos; a perda da experiência entendida nessa chave nos faz pensar numa filosofia que tenha o real como um dos elementos operacionais. Vimos nos nossos desenvolvimentos anteriores neste capítulo que, em busca de uma noção de experiência na filosofia que seja compatível com a psicanálise, fizemos um longo percurso. Nossa discussão nos leva, então, “uma nova teoria do sujeito." Este é o nome de um livro de Alan Badiou, onde podemos, uma vez mais, observar um testemunho de um autor. Ele fala sobre a situação da filosofia para o sujeito contemporâneo: "Meu objetivo é produzir um conceito contemporâneo de verdade". (Badiou, 1993) Na busca de um conceito de verdade para o sujeito moderno, vejamos como ele situa a questão do mundo contemporâneo e qual o tipo de filosofia que esse mundo necessita, já que o nosso mundo não gosta da filosofia.

Nosso mundo não gosta da aposta, do acaso, do risco, do engajamento. É um mundo obcecado pela segurança, é um mundo onde o acaso é perigoso. Um mundo onde não devemos nos abandonar aos encontros. Um mundo onde é preciso ter uma tática de vida e onde não se deve, sobretudo, apostar na própria existência. (Badiou, 2009 , p. 12, grifo nosso)

Retomemos assim, a ação e o perigo do primeiro capítulo desta tese, na etiologia mista da neurose traumática. Na dialética entre as experiências de perda constitutivas do psiquismo e a perda da experiência da modernidade está o funcionamento da ação de onde pode surgir uma transformação. No nível político, essa transformação para Badiou está na revolta, na recusa a ficar instalado e satisfeito. E aqui esta transformação se coordena com a noção de experiência em Foucault, no que diz respeito ao otimismo - "não realizo minhas análises para dizer: olha só como são as coisas, vocês caíram na armadilha. Só digo essas coisas na medida em que considero que isso permite transformá-las" (Foucault, 1980).

Alain Badiou assim como Foucault, é um inquieto, desassossegado com o mundo contemporâneo que se opõe ao desejo. Desse modo, há outro componente que 
no qual a filosofia e a nova teoria para esse sujeito moderno deveriam considerar: $a$ aposta, o gosto pelo encontro e pelo acaso. E aí se localizaria a capacidade de criação e o amor. O que é o amor senão uma gramática de recomposição de objetos perdidos ao longo da vida? Retomando Freud, Lacan, o acaso seria uma ação do destino arbitrária ao sujeito, mas que não deixa de convocá-lo a uma resposta.

Se as mães de Sêneca como demonstramos no terceiro capítulo, fizeram uma decisão depois da perda, no amor, o acaso oferece um encontro, assim como os cruisings de Barthes - uma paixão, com toda a intranquilidade que a pathos oferece. Não disse o poeta Vinícius de Moraes: “não há coisa mais triste que ter paz?” Jogando mesmo com os encontros teóricos, onde foi mesmo que Lacan disse que "aquilo que o analisante veio buscar na análise é senão o tropo dos tropos, aquilo que se chama seu destino"? Pensando novamente em termos de ação e perigo, a ação é dada pela História, e o perigo é a condição de desamparo frente a determinação imposta, há outra ação do lado do sujeito - quando escolhe, quando decide, quando trabalha por uma transformação e ama.

A filosofia deve preservar o sentido da aposta e do risco. Isto quer dizer que ela deve estar ligada à experiência dos encontros, das decisões, das rupturas subjetivas. Que deve estar ligada à escola dos acasos da paixão, das conversões, das perturbações. Que deve ser senão apenas um pensamento do que surge, do que improvável, indecidível. (Badiou, 1993, p. 17)

Vemos o funcionamento de uma retórica do "in" — "indecidível", "improvável", "imprevisto" - , onde a incidência do real não causa somente o impossível. Desse modo, a pretensão de Badiou é que seja uma filosofia cujo pensamento tenha o estatuto de um evento para o pensamento. Daí a dificuldade de se dizer o que é um evento. Um evento, assim como uma experiência, acaba por necessitar que outras discursividades surjam para tentar nomeá-lo.

O sujeito, para Badiou, existe porque a verdade o antecede; e é preciso que alguma coisa aconteça em meio às repetições para que se inicie o processo de uma verdade. É preciso que algo aconteça porque o saber proporciona repetições. "O sujeito se submete a uma rotina. A repetição é uma forma ambivalente; às vezes denota fracasso, impotência; outras podem interpretar-se como uma aspiração". (Barthes apud Jay, 2009, p. 439) 
"Para que uma verdade afirme sua novidade, deve haver um suplemento. Esse suplemento é entregar ao acaso. Ele é imprevisível, incalculável. Ele está além daquilo que é. Eu o chamo de um evento" (Badiou, 2009, p. 44). A origem do sujeito está na verdade, o sujeito não é uma origem.

Como afirmamos anteriormente que o final de um namoro pode ser tão catastrófico quanto um 11 de setembro, estamos de acordo que o conceito contemporâneo de verdade pode-se ligar ao de um evento. A verdade do sujeito que ditará suas decisões frente o traumático, sua relação com o real, rege toda sua vida psíquica. Entretanto o avesso desse acontecimento pode ser um encontro, uma paixão, um recomeço. Pois diante do encontro, o sujeito faz uma aposta, corre um risco, segue adiante. A verdade do lado do sujeito começa por uma decisão.

Badiou dá como exemplo de eventos: a Revolução Francesa; a aparição da tragédia teatral, com Ésquilo; e o surgimento da física matemática com Galileu. Não nos afastamos, entretanto, da veritas. Ligado ao passado e à narração permite que a experiência seja ouvida em: O segredo do mundo é o nó entre a pessoa e o evento. 


\section{Capítulo 4. Sofrimento decorrente da perda de experiência: a solidão}

Utilizamos a noção de fronteira no primeiro capítulo para falar do intervalo entre o eu e o outro, o caráter relacional da demanda. Neste capítulo trataremos da experiência de solidão como resíduo da dificuldade do vínculo com o outro. Esse é um dos modos como atualmente o sofrimento do sujeito moderno chega à nossa clínica. Um discurso que se localiza entre a autossuficiência e a solidão. Para esse debate, recorremos de forma breve a uma música e a um filme nacionais para demonstrar as figuras do que se chama "estar só". Vamos, antes, situar o patológico da relação com o outro no texto freudiano.

A solidão é incitada pelo luto, assim como pode responder facilmente ao encontro traumático com o Outro. A solidão é também uma experiência que, por si só, pode representar uma dificuldade para ser sustentada, mas que, por outro lado, é um traço característico e necessário da experiência. Finalmente, podemos distinguir na solidão os traços que negam a afetividade da experiência: ela nega a partilha sensível com o outro, ela nega a narrativa, ela recusa ou impede a transmissão de algo, ela suprime o encontro com o outro. Por outro lado é na solidão da escrita e da leitura que reencontramos a reconstrução, a transmissão de uma experiência. É na solidão do luto que reconstruímos o objeto perdido. É na solidão da linguagem que realizamos mais perfeitamente o caráter simbólico do outro e do objeto perdido. A solidão presta-se assim a representar perfeitamente a inversão dialética entre a experiência da perda e a perda da experiência, problema de que se ocupa esta tese.

Entre o sujeito e a civilização há um desconforto, um descontentamento e um conflito. O resíduo disso é um sofrimento:

A patologia nos apresenta um grande número de estados em que a delimitação do Eu ante o mundo externo se torna problemática, ou os limites são traçados incorretamente; casos em que partes do próprio corpo, e componentes da própria vida psíquica, percepções, pensamentos, afetos, nos surgem como alheios e não pertencentes ao $\mathrm{Eu}$; outros em que se atribui ao mundo externo o que evidentemente surgiu no Eu e deveria ser reconhecido por ele. Logo, também o sentimento do Eu está sujeito a transtornos, e as fronteiras do Eu não são permanentes. (Freud, 1930/2013, p. 9, grifo nosso) 
A partir de sua experiência da relação com os outros um certo saber é construído a fim de modular os conflitos com o mundo externo. Elaborando um saber sobre si, o sujeito cria regras de conduta, decisões, limites para suportar o conflito. Assim, voltamos uma vez mais à vasta etimologia da palavra 'experiência', só que agora ligada à forma de saber e ao sofrimento. O radical latino peri diz respeito à uma dificuldade:

Este significado aparece claramente na palavra latina periculum (que significa 'perigo'), e no verbo aperire (que quer dizer 'abrir'), nos dois casos temos a ideia de uma ação que enfrenta dificuldades ou remove obstáculos. Portanto, em sua significação etimológica, a palavra experiência quer dizer: 'vencer dificuldades', 'superar obstáculos', 'abrir novas perspectivas' e, por conseguinte, enriquecer-se e fortificar-se na luta e no sofrimento com que nos deparamos na vida. (Rocha, 2008, p. 102, grifo nosso)

A palavra experiência concerne ao humano, às dificuldades da vida e a um saber decorrente da mesma. É importante esse destaque da palavra, pois até o momento estamos associando a noção de experiência a trabalhos psíquicos, trabalho de escrita, experiência acompanhada de objeto e da perda de objeto. Mas a citação anterior mostra como, enquanto forma de saber, a experiência humana diz respeito também a um aprendizado da vida.

Ésquilo, poeta trágico da Grécia antiga, foi provavelmente quem penetrou com mais profundidade no sentido da palavra experiência como forma de saber, quando imortalizou, em uma de suas tragédias, a máxima: páthei máthos :sofrer para aprender. Temos aqui uma das mais expressivas formas de experiência trágica em relação direta com o enigma de nossa finitude e com a dor de nossos limites. Trata-se de uma "forma de saber", que só no sofrimento se consegue. No Agamêmnon de Ésquilo, o coro canta: "Ele (Zeus) abriu aos homens as vias da sabedoria, dando-lhes como lei: [sofrer para aprender] (Eschille, 1982, pp. 264-265, apud, Rocha, 2008, p. 102, grifo nosso.)

A aposta clínica e o que temos como argumento deste capítulo é que a nomeação do mal-estar trabalha em favor da mitigação do sofrimento. Com isso, temos também um paradoxo que será desenvolvido no próximo capítulo, mas que nos cabe adiantar: a própria acepção de experiência implica que o trabalho analítico concerne a uma dificuldade.

Para diminuir o sofrimento, a nomeação precisa ser um ato; ela diz respeito à fala plena, tal como desenvolvemos no segundo capítulo. A passagem do mal-estar ao sofrimento pode ser percebida na citação que se segue: 
Quando Walter Benjamin observou que os soldados que regressavam da Primeira Guerra Mundial não tinham história alguma para contar, em função da perda da articulação da própria experiência, ele não incluiu em sua consideração o desafio que isso representaria para os clínicos. Um bom clínico jamais interromperia o diagnóstico ali. (Dunker, 2015, p. 25, grifo nosso.)

A história, no contexto da acontecência, marcou para aqueles sobreviventes uma dificuldade de nomeação. Em termos do enunciado estava a guerra; em termos de enunciação, o silêncio. E um silêncio no lugar da enunciação só pode causar sofrimento, por isso um clínico não interromperia o diagnóstico nesse ponto.

Se o escopo do diagnóstico define as pretensões do tratamento e se um diagnóstico rigoroso apreende a totalidade de um quadro, há muito mais em jogo do que essa síndrome. Como em toda patologia psíquica, o centro causal é a perda de experiência, aquilo que Freud chamava de trauma, enfatizando as dificuldades de lembrar e subjetivar a experiência, e que Lacan chamava de Real, enfatizando seu caráter repetitivo e refratário a nomeação. Essa experiência impossível, que não cessa de se repetir - sem se inscrever perfeitamente-, que retorna de modo traumático, trágico e falho, representa a figura conceitual da gênese do mal-estar (Unbehagen). (Dunker, 2015, p. 34, grifo nosso)

A perda da experiência está relacionada à dificuldade de nomeação, ao traumático, ao real, àquilo do qual não se tem testemunha. Este estar só na experiência, na ausência de alguém, demarca uma gramática que queremos convidar o leitor a acompanhar. Estar só ou acompanhado parece ser uma experiência impossível. Tal como a metáfora do porco-espinho de Schopenhauer que Freud utiliza em Psicologia de grupo e análise do eu (1921), se no retorno às suas casas, no ambiente mais familiar, os sobreviventes estavam mudos, talvez a impossibilidade de nomeação tivesse alguma relação com o reconhecimento do outro. Para quem falariam? O sujeito está para sempre comprometido por uma forma de ausência.

Entre os que se queixam de solidão, mas não conseguem se aproximar de ninguém; entre as experiências de sofrimento das quais o sujeito sai transformado, nos lembramos do diário de Barthes e da sua definição de solidão: "não ter ninguém em casa a quem dizer: voltarei a tantas horas, ou a quem poder telefonar (dizer): pronto, cheguei” (Barthes, 1979/2011, p.42).

Observamos em nossa escuta clínica como a solidão oscila entre a autosuficiência do sujeito moderno e sua fragilidade. Nossa pesquisa, até o momento, nos 
oferece uma série de conceitos (objeto, desamparo, trauma) de diagnóstico de época (perda da experiência) que nos fazem trazer a solidão como o sofrimento do homem moderno, pois ela é signo do resultado de uma demanda não correspondida. Afirmamos algumas vezes que o estudo do significante experiência nos faz observar como ele está acompanhado da noção de real, de objeto e de perda; e de como, através da relação com os objetos, o sujeito modula sua relação com o outro.

Retomamos os pares opositivos do fort e do da - do texto freudiano Além do princípio do prazer (1921) - para discutir o funcionamento desses vínculos. São dois fonemas que Freud escutou de seu netinho, que, brincando com o carretel, fazia oralizações do lá e do aqui quando percebia a mãe ir e vir: o fort-da tem, dentro da teoria psicanalítica, a força de marcar uma oposição recíproca, ausência e presença.

Através do significante 'solidão', que ouvimos em nossos consultórios expressão da ausência do outro, ainda que na presença dele -, o lá e o aqui se anunciam.

A forma de matematização na qual se inscreve a descoberta do fonema como função de pares opositivos formados pelos menores elementos discriminativos apreensíveis da semântica leva-nos aos próprios fundamentos nos quais a última doutrina de Freud vê, diante de uma conotação vocálica da presença e da ausência, as fontes subjetivas da função simbólica. (Lacan, escritos, pp. 284-285, grifo nosso)

A nomeação da solidão está entre as palavras: lá e aqui, ir e voltar, ausência e presença. Se o real negativiza a estrutura das coisas, na ausência e presença do outro, vemos a relação com o desejo e a sua negatividade. Para demonstrar esse trabalho psíquico, escolhemos uma música de um cantor e compositor brasileiro, Lenine: Hoje eu quero sair só:

Se você quer me seguir não é seguro, você não quer me trancar num quarto escuro.

Às vezes parece até que a gente deu um nó, hoje eu quero sair só.

Você não vai me acertar à queima-roupa, não. Vem cá, me deixa fugir, me beija a boca.

Às vezes parece até que a gente deu um nó, hoje eu quero sair só. Não demora eu tô de volta.

Vai ver se estou lá na esquina, devo estar. Já deu minha hora e eu não posso ficar.

A lua me chama e eu tenho que ir pra rua. 
A música de Lenine é interessante para observar alguém que quer estar acompanhado, mas que, entretanto, precisa de seus momentos de solidão - como se esta fosse a expressão de uma singularidade do sujeito. E por ser a música um exercício de nomeação, ela coloca o sujeito distante de uma posição autossuficiente, porque este afirma: "Não demora eu tô de volta" - demonstrando ao outro que não se trata de uma ruptura, e sim de um breve afastamento.

No filme Hoje eu quero voltar sozinho (2014), o personagem é um adolescente cego que procura se tornar mais independente da família. Ele busca o outro nas amizades, em encontros amorosos, mas vai demarcando aos poucos um terreno que não necessita mais ser familiar. Os pais do garoto entendem o desejo de independência do filho, mas, em função do risco e do perigo, sempre arrumam desculpas para que ele tenha companhia. Todavia, o que o rapaz quer mostrar aos pais é que estes fizeram o que era possível e que ele deveria correr alguns riscos - por isso o nome do filme: Hoje eu quero voltar sozinho. Há uma cena em que a mãe do rapaz, preocupada em como este voltaria para casa depois de uma festa, lhe diz: "Mas você vai voltar sozinho, no escuro?" E ele responde: "Mas mãe, pra mim é sempre escuro!”.

Depois de nossos desenvolvimentos podemos destacar que o voltar tem tanta força quanto o sair; assim como no fort-da e na música que apresentamos, o voltar significa também um apaziguamento do conflito com o outro que saiu e que deseja retornar - pois, às vezes, decisões de sair de casa ou mudar de cidade não são nada mais que respostas à demanda do outro. Concordamos com as autoras que afirmam que

O que os pacientes nos mostram, é que ao radicalizarem sua margem de liberdade entendendo que escolher é romper com tudo que está dado, há uma irrupção de angústia e desamparo, ao se depararem com o impasse da necessidade de se diferenciarem dos outros, ou seja, de criarem essa margem de liberdade, tendem a formular frases que ultrapassam esse desejo de separação e de diferenciação, ao expressarem muitas vezes que a solução para esse impasse encontrada por eles seria anularem suas referências simbólicas. Retomamos, no entanto, que o desejo do Outro é sempre referência para o sujeito inclusive para as escolhas inseridas na margem de liberdade de cada um. (Tatit, Rosa, 2013, p. 140, grifo nosso)

O distanciamento do sujeito de suas famílias mostra como a necessidade de ruptura pode advir de um vínculo extremamente forte, onde somente uma ação, juntamente com a nomeação, pode fazer a diminuição do sofrimento. Tal como o paradoxo da Carta ao pai de Kafka: "Querido Pai: Você me perguntou recentemente 
porque eu afirmo ter medo de você. Como de costume não soube responder, em parte justamente por causa do medo que tenho de você..." (Kafka,1919/2014, p.17) Kafka afirma que necessitaria um pouco mais de estímulo, "um pouco mais de amabilidade, de um pouco de abertura para meu caminho, mas ao invés disso você o obstruiu, certamente com a boa intenção de que eu deveria seguir outro”. (Kafka,1919/2014)

O personagem do filme está mais próximo de uma experiência libertadora porque afirma que vai voltar, como se dissesse aos pais: "vocês já me mostraram o caminho". Ele não precisa "formular frases que ultrapassam esse desejo de separação e de diferenciação" como destacamos na citação anterior. Para o garoto linguagem e ato operam conjuntamente. Quando afirma que para ele tudo é escuro, extrai do saber de seu sofrimento o argumento para dizer à mãe que quer voltar sozinho; no embate entre dois desejos o sujeito consegue se posicionar. Mas, para Kafka, a carta é a escrita do abismo do vínculo entre pai e filho, uma interseção entre a ficção e a relação com o pai. Não há o confronto da negatividade de seu desejo com a negatividade do desejo do pai.

A experiência de solidão em relação à falta, ao desamparo, aproxima o sujeito do real :“A solidão é uma versão do que a psicanálise chama de separação ou castração, uma vez que nessa experiência o objeto ao qual poderíamos nos identificar, para cobrir nossa falta e a falta no Outro é finalmente deslocado de sua função encobridora". (Dunker, 2007, grifo nosso).

Podemos tentar responder se o homem moderno está mais suscetível a perdas e lutos? Por um lado o sujeito moderno é um sujeito sozinho, e o que seria patológico seria fazer dessa solidão um argumento e justificativa para autossuficiência.

O sentimento de solidão parece ser um intervalo entre os discursos sociais que engolem o sujeito e que impõe a necessidade de sermos felizes e sociáveis. Em alguns casos se sentir só é um escape da singularidade. Por outro lado, o isolamento descrito por alguns pacientes em nossa clínica aparece reforçando um registro imaginário, que valoriza falicamente a auto-suficiência, optando assim a uma colagem aos discursos contemporâneos do "um por um", do "salve-se quem puder", do "cada um por si", bem como do self-made man, self esteem, self-realization, self-reliance. (Tatit e Rosa, 2013, p. 137)

Se o sofrimento se altera na medida em que é nomeado, se é pelo outro que a doença dos vínculos se dá, não é sem o outro que ele consegue se libertar. 
Assim como um significante representa o sujeito para outro significante, assim como nenhum ato de linguagem se completa fora da relação com o outro, o sentido e $o$ saber extraídos de uma vivência só adquirem o estatuto de experiência no momento em que aquele que os viveu consegue compartilhá-los com alguém. (Kehl, 2010, p. 162)

Retomando o que discutimos no capítulo das experiências de perda, da atividade intensa do sujeito melancólico na dedicação em pensar acerca da dor de existir, concordamos com o que afirma Calligaris sobre o paradigma mórbido da modernidade: a estrutura fundamental da modernidade é um tipo específico de melancolia: a de que o sujeito não aceita o próprio destino. Para esse autor a subjetividade moderna é: "um inventário de desencontros, falsas restituições, promessas irrealizadas e elaborações melancólicas" (Matos, 1989).

\section{O sofrimento social da solidão}

No exemplo de Agamben que citamos em nossa introdução, o autor nos remete a um cenário de lá e cá, como temos demonstrado: "O homem moderno volta para a casa a noitinha extenuado por uma mixórdia de eventos divertidos ou maçantes, banais ou insólitos, agradáveis ou atrozes, entretanto, nenhum deles se tornou experiência". (Agamben, 2005, p. 22). Esse cenário em que Agamben nos convida a entrar diz respeito à relação entre o sofrimento individual e o social. "A experiência individual no sofrimento singular se expressa em falas únicas, de preferência em primeira pessoa. Por isso é importante jamais separar o sofrimento individual dos movimentos sociais que lhe deram origem" (Dunker, 2015, p. 36). No trabalho com as histéricas Freud havia reconhecido que o sofrimento destas tinha uma relação com aquilo que estava posto socialmente. Em relação à solidão como uma dessas oposições ao social, ela é uma tentativa de resistir a "ter que ser um indivíduo" (Safatle, 2012), resistir a um modo de gozo universal cristalizado nos sujeitos. Entretanto, há uma passagem importante entre o que é uma queixa de isolamento e as práticas de segregativas:

Obviamente há movimentos inibitórios que servem como tentativas de isolamento, de criação de um espaço de risco zero e protegido, buscando o velamento das dificuldades na relação do sujeito com os outros. Há ainda práticas segregativas 
advindas do Outro, nas quais a solidão passa a ser uma condição forçada. (Tatit e Rosa, 2013, p. 137, grifo nosso)

A condição forçada da solidão mostra como o social produz uma linguagem própria em relação ao sofrimento. Diante da dificuldade de nomeação, da impossibilidade de representação do real, os sobreviventes da guerra voltavam silenciados e, a partir disso, uma nova era se iniciou: "Uma era na qual as articulações entre mal-estar e sofrimento seriam reordenadas" (Dunker, 2015, p. 25).

Primo Levi, depois de sobreviver ao horror da Segunda Guerra, volta para casa e tem um sonho recorrente: as pessoas bocejavam à mesa, na hora do jantar e se levantavam e não se interessavam pelo que ele tinha a dizer. Esse fato, no testemunho de Levi, demonstra que, mesmo de volta à casa, o outro estava ausente, porque somente há alguém quando este escuta. Tal como a pequena criança que pede à tia que conte uma história porque tem medo de escuro, e a tia, dizendo que as luzes estavam apagadas, escuta da criança: algo se ilumina quando o outro fala. A voz da tia, no escuro, reconhecia o medo da criança. O medo de não ter o sofrimento reconhecido é tão nefasto quanto a impossibilidade de nomeação do mal-estar. Para Levi, o lugar onde poderia surgir o conforto, o apaziguamento da angústia, insistiu em ser, nos seus sonhos, um lugar silencioso e solitário. Disso podemos chegar a uma proposição: o efeito de estranhamento na narrativa ilustra o funcionamento do real. A insuficiência da linguagem diante do real coloca ainda mais força no trabalho psíquico e linguajeiro do fort-da, porque inclui uma ação onde a criança pode se posicionar diante a ausência do outro. Uma vez que iniciamos este capítulo com o intervalo entre o eu e o outro, observemos o poema que se segue, de Mário de Sá Carneiro:

Eu não sou eu nem sou o outro,

Sou qualquer coisa de intermédio: pilar da ponte do tédio

Que vai de mim para o outro.

Lacan, em 1964, afirma que o sujeito está no intervalo - e por isso é que a interpretação não seria apontar o sentido, mas a posição do sujeito. O sujeito, apesar da dificuldade de nomeação do mal-estar, da falta do outro como reconhecedor de um sofrimento, ainda assim, é capaz de uma decisão, tal como as mães do texto de Sêneca. 
Há uma decisão também em permitir reconhecer a própria posição. Isso é o que veremos no próximo capítulo com os relatos de análise. 


\section{Capítulo 5. Relatos: Falar de si lá onde não há mais si mesmo}

A partir dos desenvolvimentos de nossa pesquisa, podemos extrair um postulado: estamos para sempre marcados pela dificuldade de falar sobre o real, pois somos terminantemente incapazes de falar positiva e diretamente dele. Reconhecemos na existência humana várias tentativas de lidar com esse postulado. Quando se trata da clínica, essa dificuldade se soma a uma outra também bastante importante que é a definição de cura. Ou seja, tanto na filosofia, quanto na História e na literatura, temos uma grande pergunta: como nos tornamos o que somos? Quais as influências da História na constituição dos sujeitos? Na psicanálise: como nos curamos do que nos tornamos; na literatura: como escrevemos o que somos? Certos de que há uma certa encruzilhada em aproximarmos o entendimento do homem - do "ser", na filosofia, ao "sujeito" da psicanálise - , acreditamos que uma pesquisa das ciências humanas acaba sempre por passar por estas questões. Estas perguntas nos revelam que as diferentes formas de tratamento do real estão presentes no homem. Isso tem um valor importante em nossa pesquisa, pois, se a psicanálise se apresenta ao sujeito como uma alternativa ética em relação aos seus sofrimentos, ela não é a única.

Todos acabam sempre se tornando um personagem do romance que é a sua própria vida. Para isto não é necessário fazer uma psicanálise. O que essa realiza é comparável à relação entre o conto e o romance. A contração do tempo, que o conto possibilita, produz efeitos de estilo. A psicanálise lhe possibilitará perceber efeitos de estilo que poderão ser úteis a você. (Kehl, 2001, grifo nosso) ${ }^{13}$

A citação acima é uma comunicação oral de Lacan a um candidato à análise que, depois, escreve sobre este encontro e o publica anos após a morte do analista. É interessante observar que Lacan propõe que a transformação do romance ao conto é um trabalho que satisfaz as mesmas necessidades de quem faz uma análise.

Por ora, não podemos deixar de sublinhar que o encontro com o real acarreta uma transformação subjetiva que nem sempre é acompanhada de uma experiência analítica. Essa pequena introdução em nosso capítulo dos relatos de análise é importante para advertir ao leitor que:

\footnotetext{
${ }^{13}$ www.mariaritakehl.com.psc.br
} 
Qualquer um que tenha feito uma análise (e não apenas frequentado um psicanalista)...qualquer um que tenha feito uma análise para valer...a saber, tenha se posto a trabalhar a própria questão -, a se interrogar sobre a própria angústia, a se perguntar sobre isso que é inconsciente e habita nele, a investigar e destrinchar o que de "si mesmo" participa na fabricação e na autoria desse efeito tão real quanto verídico como é um sintoma, uma inibição ou um estado de angústia...Quem alguma vez tenha feito esse trabalho...sabe que a psicanálise não é um fenômeno literário. Sabe-se que, pelo contrário, uma análise é uma experiência carnal. E aí o problema que se nos apresenta é de como documentar essa dimensão material cuja incidência visa e recai sobre os avatares da própria carne. (Cabas, 2007, p. 49, grifo nosso)

A citação anterior parece se contrapor à de Lacan? Esse debate nos é importante neste momento porque demonstra a complexidade da relação entre a psicanálise e o que se escreve dessa experiência, pois, como demonstramos, é de uma escrita que se trata e por si só a escrita tem efeitos subjetivos para o sujeito. Entretanto, quando afirma que a psicanálise não é um fenômeno literário, ele parece estar dizendo que, por mais que sejam experiências análogas no que diz respeito a seus efeitos, a psicanálise apresenta alguma especificidade no modo de tratamento da dor de existir. Qual seria?

Retomando a citação de Cabas, até compreendemos que se interrogar sobre a própria angústia, buscar a remissão de sintomas, são questões dos analisantes; entretanto, é difícil determinar o que é uma análise para valer. Justamente por ser uma experiência carnal é que nos importamos e nos interessamos sobre o que os próprios analisantes dizem de como foi para eles essa experiência.

De resto, também é verdade que existem alguns exemplos da literatura universal que abordam essa experiência sem esquecer- e, portanto, sem omitir- a dor que representa a revelação de saber que se obtém no curso do trabalho analítico...Na sua maioria, relatos novelados como, por exemplo, esse texto dos anos sessenta- que leva o título de "O mal obscuro". Uma novela que narra com espantosa fidelidade a elaboração do autor, Giuseppe Berto e a tragédia que lhe significou saber de si, mergulhar nas entranhas da sua doença e descobrir a guerra sem quartel que ele vivera às voltas da lembrança com o pai morto. Uma novela onde o relato jorra em uma escrita lapidar que antecipa em pouco mais de um quarto de século o estilo de um Saramago. (Idem, 2007, p. 49, grifo nosso)

Os relatos na literatura que dizem respeito à dimensão clínica são a expressão de um saber duplo: o saber da experiência e o saber de si que essa experiência proporcionou. Daí a ocorrência de tantas indefinições, incertezas e dificuldades desse tipo de escrita. O título do relato na citação de Cabas, "O mal obscuro", revela que $a$ 
experiência de adoecer e a experiência de se tratar são distintas e que a experiência de análise diz respeito a um saber que envolve ambas. Além disso, nos cabe acrescentar à discussão que a forma como se demarca essa dificuldade de se escrever sobre a experiência analítica, onde circulam analistas, seja em escolas de psicanálise ou universidades, é uma forma marcada por impasses éticos.

Para definir o objetivo dessa parte da pesquisa, o que faremos é tentar demonstrar nos relatos o porquê de o tratamento psicanalítico ser considerado uma experiência, ou seja, que a experiência é um sucedâneo do tratamento analítico Vale destacar ainda, da citação anterior, a nomeação da escrita do adoecimento na metáfora "guerra sem quartel" - nos fazendo lembrar aquilo que trabalhamos como fronteiras na primeira parte da tese - e do real como limite da experiência. É interessante observar a ideia de perda na lembrança do pai do autor de Mal obscuro, o que corrobora nossa proposta de articular as experiências de perda do psiquismo como constitutivas do aparato simbólico, daquilo que faz querer escrever, e que faz querer superar.

Se afirmamos, anteriormente, que a experiência analítica é uma experiência que diz respeito a uma transformação, examinaremos agora como o sujeito escreve sobre sua transformação. Mas, como os efeitos de uma análise, dessa transformação, abrem um campo muito vasto para o estudo da noção de experiência, nos basearemos no trilhamento teórico feito nesta pesquisa nos capítulos anteriores: estilo, objeto e real.

Através de três relatos de análise distintos valorizamos o estilo pela diferença entre eles, pois, se a experiência psicanalítica oferece como efeito um estilo, não há um final único para o tratamento. Trabalharemos o objeto em relação à fronteira com o outro e o real como o fim do processo de análise. Não seria producente para nossos propósitos apresentar detalhadamente as experiências dos autores, convocando os nossos leitores a uma narrativa extensa sobre o sofrimento, o sintoma, a direção do tratamento. Como afirmamos em nossa introdução, a forma da experiência, nos relatos, é mais importante que o juízo sobre ela. Assim, não estamos interessados em discutir se foi uma má análise ou não, mas se estamos entendendo a experiência analítica como restituidora, reconstrutora ou reparadora de experiências de perda, estamos propondo que - apesar de o objeto estar para sempre perdido — a negatividade dessa experiência não impede que se crie e se reordenem novos saberes. 
Observamos a ocorrência de analogias e metáforas nos relatos de escrita da experiência. Vamos recorrer a uma pequena analogia, no nosso próprio texto teórico, antes da leitura dos relatos. Convidamos o leitor a fazer uma digressão ao primeiro capítulo. Naquele momento afirmamos que o capítulo encontraria sua conclusão nos relatos. Ação e perigo foram tratados em relação ao desamparo (Hilflosigkeit). Mas queremos chamar a atenção para o trabalho (Arbeit) psíquico que há quando se une a ação com a ideia de perda, afim de chamar a atenção da força de ação nas metáforas ou, melhor dizendo, para o fato de que as metáforas são uma forma de ação. Como em Waldo Emerson: "O segredo do mundo é o nó entre a pessoa e o evento."

Nosso exercício de método implica partes extraídas de relatos de análise que chamamos de fragmentos, e relacioná-los com as temáticas trabalhadas na tese. Iniciaremos com o final do processo (fronteira com o outro e o real como o fim do processo de análise). Em seguida, apresentaremos a relação com o tempo, com a necessidade de escrita da experiência, o sofrimento e sua possibilidade de falar sobre ele. Relatos:

Fragmento 1

$\mathrm{Na}$ antevéspera da conclusão de minha análise, tive um sonho. Estava à beira de um precipício do qual não enxergava o outro lado, tampouco o seu fundo. Tomei distância suficiente, corri com toda a velocidade possível e saltei sobre a fresta. Despertei. Acordado, analisei que, no sonho, não havia necessidade que eu saltasse sobre o buraco, não estava sendo pressionado por ninguém a saltar, não havia medo ou coragem, tampouco vontade de me matar. Pelo contrário, apenas havia o desejo de saltar sobre a fenda, de permanecer suspenso sobre o vazio. Não pulei, saltei o mais alto e mais longe que pude em direção ao vazio. Em um flash, só havia um corpo em suspensão no vazio, se que ninguém o segurasse, sequer pelos cabelos. Nesse momento, intuí a decisão de ir ao dispositivo do passe da Escola de Lacan. (Sergio de Campos, 2014, grifo nosso)

Campos é psicanalista e preceptor em psiquiatria do Hospital Raul Soares em Belo Horizonte. É membro da escola Brasileira de Psicanálise. O livro do qual extraímos alguns trechos para nosso debate foi publicado em 2014 e é uma coletânea de textos que foram elaborados para apresentação oral. É dedicado ao seu analista, Celio Garcia. 
Fragmento 2

Como de costume, eu não havia previsto nada. Entretanto, assim que me vi em sua presença anunciei que voltaria no dia seguinte, mas que depois não viria mais. Pareceu tão assombrado de ouvir quanto eu mesmo de formular. Tenho certeza que estávamos tristes. Nós nos olhamos longamente. Eu não tinha nada a acrescentar. Ele não fez comentário algum. Era o fim da história de amor. Ao cabo de uma travessia que durara dez anos, o passador levara o passante-passageiro são e salvo de uma margem a outra. $\mathrm{O}$ dia seguinte era o dia da última vez. O sentimento que me agitava era feito de afeição e desapego ao mesmo tempo: embora três dias antes o ignorasse, agora sabia que não tinha mais nada a fazer ali. Lacan apertou-me a mão. A porta tornou a se fechar. Eu nunca mais o veria. (Pierre Rey, 1989/2010, grifo nosso)

Pierre Rey é um escritor é um jornalista francês nascido em 1930. Em 1973 publicou seu primeiro romance, "O Grego", no qual evocava a personagem de Aristóteles Onassis; livro tornou-se um best-seller mundial. Depois de dez anos de análise com Jacques Lacan escreveu o relato e testemunho de sua experiência: Uma temporada com Lacan. Era o ano de 1989, oito anos depois da morte do psicanalista, quando seu relato foi publicado. O livro é dedicado ao seu amigo Gordo, analista, que surge inúmeras vezes em sua escrita e que recomendou a Rey um trabalho analítico. Morreu aos setenta e seis anos, em Paris, em 2006.

Fragmento 3:

Durante quatro anos, de maio de 1971 a junho de 1975, eu estive em análise. Mal ela havia se encerrado quando fui assaltado pelo desejo de falar, ou mais precisamente, de escrever sobre o que tinha se passado. Um pouco depois disso, Jean Duvignaud sugeriu aos editores de Cause Commune que um número da revista fosse organizado sobre o tema do Estratagema, e foi dentro desse quatro, cujos contornos não estavam muito bem definidos, mas bastante instáveis, imprecisos e oblíquos, que percebi por mim mesmo que meu texto estaria em seu elemento mais natural. Desde então, quinze meses se passaram, durante os quais escrevi, talvez umas cinquenta vezes, as linhas iniciais deste texto (isto é, essas que acabei de escrever), e em todas estas vezes fiquei completamente preso em recursos retóricos. Eu queria escrever, eu tinha que escrever, eu tinha de redescobrir pela escrita, através da escrita, o traço daquilo que tinha sido dito (todas aquelas páginas recomeçadas, os rascunhos não terminados e as linhas deixadas em suspenso são como lembranças das sessões amorfas nas quais eu tinha a sensação indizível de ser uma máquina de moer palavras sem peso), mas as palavras se endureciam em frases cuidadosamente escolhidas e naquilo que alguém poderia supor que eram as questões preliminares: por que eu preciso escrever esse texto? Para quem ele é realmente destinado? Por que decidir escrever, publicar, tornar público aquilo que talvez fora nomeado apenas na intimidade da análise? Por que 
decidir ligar essa procura incerta ao tema ambíguo do Estratagema? Todas essas questões eu me fiz com uma determinação suspeita - a primeira em letras minúsculas, a segunda em letras minúsculas, a terceira em letras minúsculas, a quarta em letras minúsculas-, como se realmente tivesse de haver questões, como se, não havendo questões, não houvesse respostas. Mas o que eu quero dizer não é uma resposta, é uma afirmação, um fato concreto, algo que aconteceu, que jorrou. Não algo que pudera estar enrodilhado dentro de um problema, mas sim algo que estava lá, bem perto de mim, algo de mim que precisava ser dito. (Georges Perec, 1975/2005, grifo nosso)

Georges Perec era escritor e poeta. Nasceu em 1936, em Paris, onde viveu quase toda a sua vida. Era membro do OuLipo (Ouvroir de Littérature Potentielle). Na infância fez análise com Françoise Dolto e, na vida adulta, com Jean Bertrand Pontalis. Perdeu os pais no front na Segunda Guerra Mundial. Escreveu W ou a memória da infância e Vida Modo de Usar, entre outros. Morreu em Ivry, em 1982.

Três escritas distintas sobre a experiência de análise. O que há em comum entre elas? Os trechos escolhidos acima dizem respeito ao final do processo e ao início da escrita sobre o mesmo. As perguntas de Perec podem ser feitas a todos. Retomando-as: por que eu preciso escrever esse texto? Para quem ele é realmente destinado? Por que decidir escrever, publicar, tornar público aquilo que talvez fora nomeado apenas na intimidade da análise? Não encontraremos respostas a elas; entretanto, a elaboração das mesmas nos convoca a formular hipóteses. Três finais de análise distintos com intencionalidades distintas de escrita da experiência.

Observemos o que destacamos em cada um desses recortes. Em relação a um certo espaço e a um limite temos em Campos: estava à beira de um precipício; em Rey: de uma margem a outra; em Perec: contornos não muito bem definidos. Nos três casos há um limite espacial, uma fronteira, uma demarcação.

Em Campos, o fim de sua análise foi sonhado e continuou no despertar se articulando com a ideia do passe. Em Rey, o final diz respeito a uma despedida e em Perec a um desejo de escrever sobre o processo. Embora todos desejassem escrever, tanto que o fizeram, os dois escritores tomaram como destino final do processo a experiência de escrita: o público em geral - enquanto Campos tinha um público específico em mente. Poderíamos inferir as seguintes perguntas: por ter uma relação especial com a escrita, Rey e Perec se dedicaram a tomar a escrita como sucedâneo da 
experiência? E por ser analista pertencente a uma escola de psicanálise lacaniana, Campos prefere o discurso oral?

\section{Fragmento 1:}

Vinte e cinco anos mais tarde, ao procurar a análise, vieram à tona as duas cenas. Primeiro a segunda, que encobria a primeira. Com efeito, o sujeito as relatou inúmeras vezes. Esmiuçou cada detalhe, trabalhou cada perspectiva e elaborou diversas versões dessas duas cenas ao longo dos anos, sem que o analista desse o menor sinal de cansaço ou emitisse qualquer interpretação. A cada sessão que as cenas se revezavam no discurso, o analista as escutava com atenção e interesse, contribuindo para que o afeto ligado a elas, gradualmente, se dissipasse. (Campos, 2014, p. 25, grifo nosso)

\section{Fragmento 2:}

Hoje sei que, recalcadas, as palavras nos alcançam e nos atravessam cedo ou tarde, nem que seja no instante de nosso último suspiro quando, num único segundo de intensidade, cada um de nós paga em bloco tudo o que ainda devia. Eu acabava de entrar no décimo ano de análise. Com o distanciamento, dizê-lo me faz sorrir pela inevitável pergunta que a confissão provoca: "Dez anos...Como é possível?” Eu mesmo seria incapaz de explicar. Simplesmente nem os vi passar. Sobretudo por não haver antinomia entre minhas visitas a Lacan e minha vida "normal": eu amava e trabalhava como todo mundo, e existia Lacan. Eu nunca tinha me perguntado quanto tempo duraria o trabalho que iniciara sob sua tutela. Nesse meio tempo, embora nos papéis tivesse ganhado dez anos, sentia-me mais jovem. E mais velho também. Curiosa mescla onde se superpunham os tempos da infância e do homem. (Pierre Rey, 1989/2010, grifo nosso)

\section{Fragmento 3:}

Eu bem poderia escrever "que demorou quatro anos para começar" ou "que terminou durante quatro anos". Não houve nem começo nem fim. A análise já tinha começado muito antes da primeira sessão, na lenta decisão em minha mente para submeter-me a uma análise e na escolha do analista. A análise continua, muito depois da última sessão, na sua duplicação solitária, que mimetiza tanto sua obstinação quanto as falhas em mover-se para frente. Em uma análise, ou você está muito agarrado no tempo, ou o tempo é inflado. Por quatro anos, a análise tinha o seu lado rotineiro, ordinário: pequenas marcas nas agendas, o trabalho espaçado pelas sessões sucessivas, a regularidade com a qual elas voltavam, seu ritmo.

A análise era em primeiro lugar isto: uma certa divisão nos dias - em dias com e dias sem -, e nos dias com, algo que se assemelhava a uma dobra, uma prega, um bolso: na estratificação das horas, um momento que era suspenso, era outro; um tipo de pausa ou um intervalo na continuidade do dia. 
Havia algo de abstrato nesse tempo arbitrário, algo ao mesmo tempo tranquilizador e assustador, um tempo imutável, atemporal, um tempo imóvel em um espaço improvável. Sim, claro, eu estava em Paris, em uma vizinhança que conhecia bem, em uma rua onde até já tinha morado, a poucas quadras do meu bar favorito e de alguns restaurantes conhecidos, e eu podia ter-me divertido calculando minha longitude, latitude, altitude e o caminho que estava seguindo (minha cabeça oeste-norte-oeste, meus pés leste-sul-leste). Mas o protocolo ritual das sessões expulsava o tempo e o espaço dessas balizas. Eu chegava, tocava a campainha, uma moça vinha e abria a porta. Eu esperava alguns minutos em uma sala destinada a esse propósito; podia ouvir o analista indicando a porta ao paciente da hora anterior. Alguns momentos depois o analista abria a porta da sala de espera. Ele nunca cruzava a soleira. Eu seguia na frente dele e entrava no consultório. Ele me seguia, fechava as portas - havia duas delas, formando um pequeno lobby de entrada, algo como uma câmara de vácuo que aumentava a sensação de enclausuramento - e vinha sentar-se em sua poltrona enquanto eu me estendia no divã. (Perec, 1977/ 2005, grifo nosso)

Nos relatos observamos a temporalidade e o ritmo da experiência. Como discutimos no capítulo sobre Benjamin e Freud, o pano de fundo das relações entre os homens diz respeito também à temporalidade. Assim, na leitura dos relatos vemos como a experiência diz respeito a uma narrativa linear e ritmada durante um determinado tempo. Em $O$ narrador (1936), Benjamin cita Paul Valéry: "o homem de hoje não cultiva o que não possa ser abreviado." Assim como no relato de Perec do fragmento anterior: "A análise era em primeiro lugar isto: uma certa divisão nos dias — em dias com e dias sem - , e nos dias com, algo que se assemelhava a uma dobra, uma prega, um bolso". Vale lembrar o que, em latim, fletir é dobrar, e refletir é dobrar-se sobre si mesmo.

Ainda que não seja nosso objetivo, sobre o tempo comprimido, nos lembramos da proposta de Lacan acerca do tempo lógico, que não necessariamente significa sessões curtas, mas que demonstra como o corte da sessão diz respeito a uma temporalidade. Ou até mesmo, numa forma mais simples de dizer, como a regulação do tempo da sessão também diz respeito a modulação da angústia do paciente e do analista. O instante de encerramento da experiência provoca em cada uma posição diante da morte. Não queremos dizer que o fim do tratamento se ligue a algum tipo de trauma, por mais que algumas saídas de análises possam ser um tanto quanto traumáticas; o que observamos nos relatos é que o ritmo da vida foi transformado pelo tempo de análise. A ponto de Rey dizer: de repente, dez anos! Um tempo que deixou de ser marcado provavelmente é um tempo subjetivado pela experiência. Entretanto, foi justamente em relação ao tempo 
que Rey se viu na encruzilhada de sua angústia: "Eu não fazia estritamente nada. Tornara-me um tragador de tempo. Aspirava-o gota a gota, atento a seu escorrer, cujo sentido e gosto eu ignorava quando eu era obrigado a não perdê-lo, no tempo em que nunca me dava o tempo de ter tempo" (Rey, 1989/2006, p. 16). Entre a experiência de ter tempo para tudo e a inutilidade das marcações dos relógios, ele escreveu como vivia:

Por horror de enfrentar o vazio, fabricava-me vacuidade. Por temor inconsciente de minha própria liquidação, anulava por meio de um "fazer" o espaço que se reduz a cada instante para nos aproximar da morte. Com o passar dos séculos, deslizamos do Cogito ergo sum ao "faço, logo sou" tão desprovido de lógica como o Credo quia absurdum. Infelizmente, havia absurdos que eu não engolia. Desde que me colocara sob o signo do "sou porque não faço", aprendera que não há tempo objetivo pois, segundo minha vontade, podia torná-lo elástico, reduzi-lo a nada enquanto giravam as estrelas ou fazer dele um infinito no tempo de uma centelha. $\mathrm{O}$ não fazer dera-me este presente de reis: poder dar ao tempo a duração do desejo. (Rey, 1989/2006, p. 17, grifo nosso)

A citação anterior parece demonstrar ainda mais o que desenvolvemos sobre o tempo em Walter Benjamin, um tempo acelerado que acaba por impor ao sujeito contemporâneo um aproveitamento máximo das marcas do tempo, onde fazer se iguala a ter - e, para fazer, há que se apropriar totalmente das horas dos dias. "O tédio é o pássaro do sonho que choca os ovos da experiência" (Benjamin, 1936/1996, p. 204); nessas palavras, Benjamin supõe uma desaceleração para poder ser. $\mathrm{O}$ faço, logo sou, demonstra como o tédio está a serviço da angústia para o sujeito moderno. Entretanto, a angústia está na ausência de mediação, um tempo que não pode ser marcado — um tempo infinito, um tempo que visa ao afastamento da morte-, e que, na ausência da marca, produz um efeito inverso, aumentando a angústia, como podemos observar no parágrafo que se segue:

...duração e intensidade se repelem. A barra que as separa marca a fronteira entre prazer e gozo - para atingir o gozo, é preciso morrer ao prazer. Para entrar na intensidade, escapar da duração que, ao balizar o prazer, o limita. O gozo aniquila: tempo sem duração, tempo fora do tempo dos poetas e de sua famosa segunda eternidade que só o medo, a morte, a vitória e o amor proporcionam. Até o tédio me era gozo, sobretudo o tédio, que me ensinara essa verdade: "somos o que fazemos" para o olhar do Outro; para o nosso, "somos o que gozamos". (Rey, 1989/2006, p. 17, grifo nosso) 
A tentativa da eternidade na marcação das horas do dia era incompatível ao sucesso. Privado de sua escrita, Rey vivia num apartamento com todos os seus pertences postos em mais de cinquenta caixas, organizadas para serem transportadas a qualquer momento. Como estava aprisionado às horas, estava também sem dinheiro algum, e o vazio do qual se queixava era experimentado também no espaço proporcionado entre as caixas e na possibilidade de ter seus pertences confiscados por um oficial de justiça:

Comia quando estava com fome, adormecia quando tinha sono e acordava quando abria os olhos. Via o sol nascer, traçar sua elipse, desaparecer no oceano, e ficava quase chocado com esse movimento que incomodava o silêncio ao escandir horas das quais eu possuía o sentido mas perdera a conta. (Rey/1989/2006, p. 18, grifo nosso).

A ação ou não ação cadenciavam seu tempo. Do "penso logo existo" ao "sou onde não penso", ele se situava no "sou onde não faço". O cálculo do tempo perturbava o cálculo das contas; se não fazia para poder ser, não poderia fazer dinheiro para ter, com receio de perder a liberdade em bens que lhe possuíssem.

Voltando para casa, sentei no chão do apartamento em meu lugar favorito, na frente de minhas caixas. Empilhavam-se até o teto e continham o que no passado haviam tido para mim um valor de tesouro: livros, manuscritos, objetos, roupas. Há três anos eu não as abria, mas gostava de contemplá-las quando esbarrava num problema...um dia, no tempo em que jogava, haviam-me avisado de que "oficiais de justiça viriam no dia seguinte com um mandado de busca e apreensão". Aconselharamme a colocar fora de seu alcance os "objetos preciosos". Às duas da manhã, eu fizera uma espécie de inventário. Um "objeto precioso" era o quê? (...) Eliminara quase tudo, salvo alguns livros com dedicatórias de amigos (...) Doravante, como não estava apegado a nada, seria sempre rico. Só amava a vida e a liberdade. Fora estes bens, não podiam me tomar nada. De manhã, os oficiais de justiça não apareceram. Tendo renunciado mentalmente ao que iam me tomar, fiquei quase decepcionado por não terem me livrado daquilo. (Rey, 1989/2006, p. 34, grifo nosso)

O trecho anterior nos faz rever o que trabalhamos na parte I de nossa pesquisa acerca do real. Rey esperava que algo acontecesse, estava à espera do real na visita dos oficiais de justiça. Entretanto, numa experiência que ainda não era experimentada em termos do destino, ele fica na mesma, paralisado - quando nada saía do lugar e nem suas caixas tinham sido removidas.

Eu tinha um terror mórbido das posições adquiridas, da repetição, das certezas. Tudo que comprometia o futuro estragava-me o presente. Dessa vez recebi mais que a encomenda. Perdi o emprego, rompi com os meus, passei a fugir dos amigos e relações e afastei-me dos lugares que frequentara. Tábula rasa. Há anos que corria atrás de minha 
própria sombra. Precisava tomar fôlego. Ainda não sabia o que desejava, embora já tivesse pago caro para descobrir o que não queria mais. Muito mais tarde, leria a frase de Lacan: "Os não-patos erram". Naquela época, nenhum outro jogo de palavras teria me caído melhor: eu errava. (Rey, 1989/2006, p. 25, grifo nosso)

Rey, não podendo ser marcado pelas horas, pelo limite da justiça, revela que aquelas caixas eram a alegoria de sua situação.

Nesse momento pediu a um amigo que lhe indicasse alguém para se tratar. Ouviu três nomes: Clavreul, Lacan e Perrier.

O nome de Lacan era-me perfeitamente desconhecido. Ouvi-o pela primeira vez da boca de uma moça loura que morava no edifício em frente e que, sabendo que eu a olhava, passeava nua há vários dias diante da janela. Uma tarde fui lá. À noite, perguntou-se se queria ir com ela "tomar um drinque com amigos em casa de Lacan, vai ser gozado". Eu devia ter outra coisa para fazer. Mas por que, tanto tempo depois, lembrei desse nome? (Rey, 1989/2006, p. 25)

A citação anterior nos faz pensar que, quando escutou os nomes dos analistas da boca de seu amigo, não se lembrou de que o nome de Lacan havia estado na boca de uma mulher. Ademais, de alguém que o havia convidado a socializar. Negando o convite, foi possível começar a análise posteriormente com aquele anfitrião desconhecido, já que, no período entre caixas, tinha uma grande dificuldade de socialização.

(...) Fora a mulher que eu amava - a quem só tive vontade de informar cinco ou seis anos depois- é preciso dizer que reduzira meu círculo social ao mínimo. Há muito fugia dos contatos rápidos, múltiplos, superficiais e sem futuro a que uma certa forma de jornalismo parece suscitar. Haviam gerado em mim tanta náusea que, se eu tivesse imaginado o inferno, tê-lo-ia concebido como uma cena de ostentação social: um salão de festas brilhantemente iluminado. Preso no centro, com um cigarro numa mão e um copo cheio na outra, sou agredido pela dona de casa que faz desfilar à minha frente, para apresentá-las a mim, pessoas que nunca tornarei a ver. (Rey, 1989/2006, p. 41, grifo nosso)

Apesar de nenhum momento do livro Rey ter falado em tédio ou solidão, gostaríamos de propor um paralelo com a clínica atual no que diz respeito ao que denominamos de sofrimento decorrente da perda da experiência. Ou seja, Freud e Benjamin fazem um diagnóstico social muito próximo no que diz respeito ao vazio do 
sujeito moderno. As narrativas dos pacientes em nossa clínica são frequentemente acerca da ruptura dos pacientes com suas famílias - um desajuste entre os próprios interesses e interesses dos pais, por exemplo. O imaginário de uma vida sem conflito ganha seu auge. Quanto mais tentam fugir de conflitos, mais os assumem; quanto mais negam seguir os ideais dos pais, mais os cumprem. A retórica da autosuficência ocupa seu lugar de destaque.

Rey, entretanto, não assume uma posição autossuficiente, a sua fuga dos eventos sociais pode representar o que os pacientes hoje denominam como solidão em nossos consultórios. Ou seja, a aversão à necessidade de sermos felizes e sociáveis. Rey chega a falar em vacuidade, mas o que ele mesmo falava sobre si era que tratava-se de um fóbico cujo objeto da fobia era o Outro. É como se ele se perguntasse: Por que devo ser bem relacionado socialmente? É interessante localizar o momento em que o autor relata o nome de sua angústia e apresenta também o que pôde fazer com a mesma durante o tratamento. "Três meses depois do início das sessões, a maioria dos sintomas aparentes que me haviam levado a seu consultório tinham desaparecido. Parece que eu era "fóbico"” (Rey,1989/2006, p. 55) - embora seu relato não indique a busca de um ambiente protegido e sem riscos.

Confessá-lo hoje me faz sorrir: continuo tão fóbico quanto antes. Mas, nesse meio tempo, negociei com minhas fobias. Ou não me coloco mais em situações em que tenha de aguentá-las ou, se for obrigado, considero-as como um acidente de um tempo vazio, suporto-as com a resignação entediada que as fatalidades exteriores merecem. (Rey,1989/2006, p. 56, grifo do autor)

Nesse parágrafo vale observar que o que o próprio autor sublinhou e o que sublinharíamos (acidente de um tempo vazio). Trata-se da diferença de uma existência não marcada pelo destino à nomeação do sofrimento como acidente de um tempo vazio, ou seja, o sintoma do sujeito corresponde ao período da vida delimitado entre caixas e inábil socialmente. A expressão disso alcança uma outra definição de sua experiência de análise, quando mais adiante no livro afirma que "a experiência de análise é a descoberta da felicidade de ser vulnerável”. (Rey, 1989/2006, p. 114)

Gostaríamos de chamar a atenção para as palavras 'resignação' e 'vulnerabilidade' escritas por Rey. As expressões na versão francesa são exatamente as mesmas: resignación e vulnerabilité. Nas partes anteriores dessa pesquisa acreditamos 
ter trabalhado que, na verdade, a dificuldade do sujeito é com a falta de objeto desamparo, em Freud; falta, para Lacan (sendo que uma das grandes contribuições deste é a negativização do desejo e o tratamento simbólico do real). Assim, a resignação diz respeito não a uma aceitação da realidade, mas sim de uma responsabilização com ela, um acordo, por assim dizer. E a vulnerabilidade está na surpresa que o real pode oferecer - que, como foi visto nas neuroses de guerra, pode vir a ser um efeito terapêutico. $\mathrm{O}$ momento do relato de Rey em que surge esse novo tratamento com o real em sua vida é o que se segue:

Soube que uma página fora virada, que eu nunca voltaria atrás. Deliberadamente, acabara de optar pelo aleatório. Mas o real é um grande mestre. Se amanhã a vida me atropelar, se me privar de minhas escolhas mas eu continuar a ter vontade de vivê-la, aceitarei pagar o preço que for fazendo o que a necessidade ditar para prolongá-la. Sem ver nisso a mínima perda de liberdade. (Rey, 1989/2006, p. 75)

No que concerne a socialização, há uma pergunta que Lacan faz a Rey que parece importante aos que se interessam pela questão do debate acerca da normatividade em psicanálise. O analista pergunta de cara a seu paciente: "Você bebe?" Pergunta importante já que, se bebesse, talvez tivesse menos problemas em enfrentar as festas. Se não bebesse, poderia estar cumprindo os ditames sociais de uma vida saudável e equilibrada. "Perguntou-me a queima-roupa se eu bebia. Fiquei pasmo" (Rey, 1989/2006, p. 38). Seria normativa a pergunta de um analista acerca dos vícios dos pacientes? Ou um resquício de humanidade daquele que escuta silenciosamente e que não se exime de tratar inclusive os que querem se destruir?

A primeira parte da análise de Rey foi atravessada pela dificuldade nas questões financeiras. É interessante observar que Rey era um crítico do sistema em que vivia. Se isso apareceu anteriormente na pergunta do porquê de ele dever ser sociável e manter boas relações com os outros, aparece também quando o analisante critica a busca de certezas. E o faz da seguinte maneira:

No transcurso de sua existência, o ser humano só possui uma certeza: a da morte. Por silogismo, é fácil deduzir o desejo inconsciente de morte metaforicamente contido em toda busca de certeza. Quando um rapaz de vinte anos aceita preencher o desconhecido de seu desejo com um plano de carreira que independa dele - ao beirar os sessenta, ele acabará presidente da empresa que o contrata -, eliminando todo acidente de percurso, pode-se estar certo de que, como escolheu repelir de sua vida tudo que o imprevisto poderia abrir no campo do gozo, aspira a morrer por medo de viver. Um 
paradoxal milagre pode salvá-lo de quarenta anos de pura perda: o fracasso. Pois é onde se fracassa que se é bem sucedido. (Rey, 1989/2006, p. 62, grifo nosso)

Observamos neste fragmento o que viemos desenvolvendo acerca de uma negatividade. Repelir o contingente, o imprevisto, estaria no exercício de uma busca de certezas. A negatividade posta na frase "onde se fracassa que se é bem sucedido" mostra como o modelo daquilo que é uma experiência em psicanálise é sempre um modelo negativo. Há um princípio de contradição (ganhar o nome e se alienar) para a manutenção do real na estrutura das coisas, negativizando-as. Algo que fracassa para ser bem-sucedido é algo que foi tocado pelo real.

O voo saía pouco antes da meia-noite. Avisei a minha companheira que preparasse uma maleta. Nem me perguntou para onde: "calor ou frio? - calor", disse-lhe. Algumas horas depois, lá estava eu no meio de uma gauguin.

Um cavalo branco, azul sob a luz da alvorada que se anunciava, pastava uma grama de um verde profundo salpicada de flores vermelhas ladeando uma praia bordada de palmeiras e buganvílias.

Soube que uma página fora virada, que eu nunca voltaria atrás.

Deliberadamente, acabara de optar pelo aleatório.

Mas o real é um grande mestre. Se amanhã a vida me atropelar, se me privar de minhas escolhas mas eu continuar a ter vontade de vivê-la, aceitarei pagar o preço que for fazendo o que a necessidade ditar para prolongá-la.

Sem ver nisso a mínima perda de liberdade pois minha única liberdade verdadeira só depende de mim, eu a possuo, deixar a vida se o desejo me abandonar. (Rey, 1989/2006, p. 75, grifo nosso)

Destacamos na citação anterior, a decisão, a ação de Rey optar pelo aleatório. De uma decisão simples como uma viagem, Rey, em seguida, desloca a ação ao perigo - no caso de que a sua vida "o atropele".

Ainda sobre a remissão dos sintomas, já que Rey afirma que a fobia não se afastou dele, encontramos uma citação de Freud que diz respeito a isto:

E que diz a experiência sobre isso? Talvez não seja ainda suficientemente e abarcadora para pronunciar uma decisão segura. Com frequência corrobora nossas expectativas, mas não sempre. Temos a impressão que não se surpreenderia se ao final resultasse a diferença entre o não analisado e sua conduta anterior em relação ao analisado, não é tão radical quanto ambicionamos, esperamos e afirmamos. (Freud, 1937, p. 230, grifo nosso). 
A citação anterior nos faz retomar a questão da transformação que uma experiência oferece, como discutimos sobre a escrita transformadora no capítulo 2: "uma experiência é algo do qual se sai transformado" (Foucault). Entretanto, Freud afirma, em 1937, que o efeito de uma análise não é bem como ambicionamos, tal como nas palavras de Perec: “A psicanálise não se parece em nada com aqueles anúncios de restauradores para cabelo: não existe nenhum "antes" e "depois" (Perec, 1977/2005)

\section{Sergio de Campos}

Alguns fatores influenciaram em nossa escolha pelo livro de Campos (2014): a atualidade da publicação, o fato de o autor ser um clínico praticante da psicanálise e, principalmente, o título — que nos chama bastante a atenção —: Passema.

Caro leitor,

O Passe é o acontecimento da Escola que melhor encanta o praticante da psicanálise. Ele é um sopro de esperança para qualquer analisante que deseja receber, da Escola, a garantia de formação como psicanalista a partir de sua experiência...O que se tem a oferecer ao Passe é apenas a experiência de uma análise, entretanto, isso não é pouco para quem deseja se tornar analista. Com efeito, o passante legitima a natureza do saber narrativo. Ele, como narrador, não pretende expressar sua competência em contar histórias, mas apenas narrar em forma de testemunho a performance de uma experiência por ele vivida. $\mathrm{O}$ narrador declara seu relato como exposto, mesmo se seu desempenho narrativo for fortemente inventivo. (Campos, 2014, p. 13,14 , grifo nosso)

Assim é a apresentação do livro do autor. Escolhemos esta citação porque ela declara a quem se dirige, ou, melhor dizendo, como se dá a partilha de saberes: para aqueles que pretendem ser analistas. A experiência analítica é aquilo que se oferece à escola de psicanálise. É interessante observar a afirmação de Campos sobre aquele que oferece a sua experiência: "como narrador, não pretende expressar sua competência em contar histórias". (Campos, 2014, p. 13). Desse modo, não há a tentativa de recuperação da experiência tal qual proposta por Benjamin. Não se trata do mesmo narrador. Provavelmente por se reconhecer como um sujeito divido, essa não seja uma das pretensões. Mas nos pareceu importante a figura do narrador surgir associada ao passe, à prova de que ali houve uma experiência. Não estamos nos opondo ao passe, ele é uma 
escolha do sujeito, mas o que queremos destacar é que é um sujeito com um compromisso distinto de testemunho.

Ao longo do livro o leitor se informa de situações importantes da vida do autor, o que o levou à análise - as duas cenas fantasmáticas que o perturbaram durante anos. Mas, voltando à sua forma de escrita, é importante observar:

A psicanálise é uma disciplina de sobrevivência, como assinalou Éric Laurent. Nela encontrei os recursos para me salvar. Posso dizer que o conjunto dos testemunhos, o qual nomeio de "Passema", é uma gramática do amor e uma gramática do sintoma extraída de minha hystoeria. Nesse "Passema", você descobrirá o passe poema e também o passe matema, que é o passe atomizado no que concerne sua transmissão. (Campos, 2014, p. 15, grifo nosso)

Acreditamos que, com a citação acima, chegamos num ponto importante no nosso debate: quais os impasses que a formalização excessiva nos apresenta? Numa pesquisa acerca da noção de experiência, sobre sua perda e sua tentativa de recuperação, apostamos numa gramática da negatividade, num trabalho aparentemente incompatível com uma transmissão sem resto. A própria palavra 'transmissão' envolve um problema, pois ela não pode cobrir, na realidade, a totalidade da experiência subjetiva.

Em nossas investigações sobre a experiência na filosofia, concordamos com a inquietação de Badiou em relação ao evento e ao amor:

Do sujeito, há sempre algo que escapa à sua formalização, à sua captação lógico-matemática, in fini, `a sua transmissão pelo saber formal. Em que sentido? Pelo fato de o sujeito, para o último Lacan, estar inextrincavelmente ligado ao real. O real, em seu teor conceitual lacaniano, é o que resiste absolutamente à simbolização, que pode se efetuar por meio da matemática, da lógica e da topologia. Esse tema é recorrente: o ponto real do sujeito é não simbolizável. Lacan, por conseguinte, foi o mais longe possível na formalização para experimentar o impasse fundamental. Em determinado momento, a formalização integral deve se interromper, por não funcionar mais sobre aquilo que pretendia apreender. É o momento em que se atinge o ponto real do sujeito. (Badiou, pp. 72-73, 2011/2012).

Ou seja, para dizer o que é uma experiência é necessário recorrer a outro campo discursivo, a outro campo do saber, e nisso já há uma perda da experiência.

Há uma discussão sobre os efeitos de uma análise perceptíveis ou não em uma escrita da qual não podemos nos eximir. Retomando o comentário de Lacan a um 
candidato à análise, em nossa primeira citação deste capítulo: "A contração do tempo, que o conto possibilita, produz efeitos de estilo". O que acontece com os efeitos de estilo de quem escreve? Ou seja, se o estilo é aquilo que o sujeito tem de mais real, como inserir a discussão dos efeitos de uma análise em escritores?

Trazemos o autor uma vez mais para a esta discussão com o que demarcamos no segundo capítulo: "podemos inferir que há algo homogêneo entre a fala e a escrita, e essa homogeneidade tem para nós, um estatuto de uma questão". Pois bem, Perec, sob o signo de luto pela morte dos pais no front na segunda guerra, foi levado à uma analista - que, sabemos, tinha uma posição importante no que tange ao tratamento do real naquelas circunstâncias históricas. Françoise Dolto era conhecida por sua autenticidade em relação à negociação com a realidade. Chegou a ter programas na rádio para que pais e crianças pudessem ter um canal aberto para perguntas acerca dos sofrimentos infantis, e se dedicou aos cuidados de bebês e crianças pequenas que eram afastados dos pais como se fossem afastados de uma catástrofe, pois muitos destes precisavam abandonar seus filhos para que estes tivessem alguma possibilidade de sobreviver.

Não vamos nos estender na apresentação de Dolto e em seu estilo; entretanto, este comentário nos pareceu importante, pois foi Dolto a analista de Perec — por volta do ano de 1947 — durante um ano ou dois. Aos vinte anos foi analisante de Michel de M'Uzan e, depois, de Pontalis. Depois dessas experiências de análise, escreveu W ou a memória da infância (1975/1995) e o texto que consultamos: "A cena de um Estratagema" (1975) — de onde retiramos os primeiros fragmentos deste capítulo. Ou seja, o término de sua análise, como o próprio Perec indicou, foi um incentivo à escrita.

O que da experiência de escrita pode ser homogêneo à experiência de fala que é uma psicanálise? Sem pensarmos que esgotaremos a discussão desse tema, propomos a leitura de um outro fragmento de Perec, que não está em nenhum desses textos que podemos nomear de "pós-analíticos". Em Vida modo de usar (1978) encontramos, no abrigo das metáforas, uma narrativa muito próxima ao que entendemos como aquele sujeito dividido; uma narrativa, portanto, situada na gramática de uma negatividade. Vamos sugerir duas figuras para pensar a experiência de perda em relação ao objeto $a$ : a primeira, a de um quebra-cabeças (puzzle); a segunda a do caco de vidro, do estilhaço. 
Perec afirma que um verdadeiro puzzle é aquele que mantém um enigma. Para tanto, um puzzle deve ser branco, sem imagens, e estruturar sua característica enigmática através de seus cortes, feitos pela guilhotina que separa os pedaços de madeira do qual o puzzle é feito. Na proposta de Perec sobre o que é um puzzle, o que se destaca é a função dos cortes, da separação que foi feita na peça inteira. Assim, para que um jogo possa ser montado, para que seja prazeroso dedicar-se à união das peças, é fundamental que haja um corte, uma separação.

Não é o assunto do quadro nem a técnica do pintor que fazem a dificuldade do puzzle, mas a sutileza do corte, e um corte aleatório produzirá necessariamente uma dificuldade aleatória, oscilando entre uma facilidade extrema para as bordas, os detalhes, as manchas de luz, os objetos bem definidos, os traços, as transições, e uma dificuldade fastidiosa para o resto: o céu, sem nuvens, a areia, a pradaria, etc. (Perec, 1978/2009, grifo nosso)

Depois de resolvidas, as peças não indicarão qual imagem se formou: o que está em jogo é o prazer da experiência de montá-las. Como na clínica, para que um jogo se estabeleça, há que existir um corte. O sujeito, dividido, estará situado na gramática da negatividade. Este trabalho de buscar figuras da negatividade na escrita, ou seja, demonstrar como a incidência de perda se dá em uma psicanálise, encontra expressão na seguinte citação:

Em suma, Lacan tentou condensar as variedades da experiência de perda com a noção de objeto $a$ e as variedades da perda da experiência com a noção de sujeito dividido. O corte é a figura conceitual que representa a não identidade entre um e outro. (Dunker, 2005, p. 282, grifo do autor)

Quanto à figura do caco de vidro e do estilhaço, numa oportunidade de observar o termo na língua espanhola, nos surpreendemos com a palavra añicos, cujo correspondente na língua portuguesa é estilhaço. Foi na tradução de uma lingua a outra que percebemos que um estilhaço é o resultado de um despedaçamento é um fragmento que continua fazendo seus cortes. Certos de que as variações da perda de experiência são, portanto, infinitas, encerramos este capítulo convidando o leitor para as considerações finais. 


\section{Considerações finais}

Em reunião de orientação, ainda na época do mestrado, discutiu-se que uma revista brasileira havia publicado o resultado de uma enquete sobre o que as pessoas salvariam de suas casas em caso de incêndio. A conversa do grupo se direcionou à observação de que todos os entrevistados haviam dito que salvariam seus computadores onde estavam suas fotos de família. Naquele momento, às voltas com o estudo da memória em psicanálise, supus que este desejo de permanecer com as fotos seria uma tentativa de salvar as recordações do esquecimento, ou servir para dar provas às dúvidas acerca do trabalho da memória: o tempo, a morte, o luto - na tentativa de eternizar um momento com alguém querido. Aquela experiência desconcertante da jovem pesquisadora, quando entrevistou pessoas acerca de suas lembranças de análise, deu lugar - nesta pesquisa de doutoramento - ao fato de que, na fotografia, a memória toca o real. Esta transformação de acepção da memória foi realizada ao longo do meu percurso de pesquisa na universidade.

Estava mais interessada na memória a serviço da clínica, das associações e recordações da infância; mais na memória que era preservada pela inconsciência do que na memória ameaçada na História. Faltava ainda em mim uma maturidade teórica para que eu percebesse a História como aquela que costura a memória nas narrativas.

Os textos sociais de Freud como Mal-estar na civilização e Futuro de uma ilusão retornaram à minha pesquisa, associados à leitura de textos acerca da guerra, com meu encontro com o Laboratório de Teoria Social Filosofia e Psicanálise e com a percepção de que a teoria freudiana é contemporânea de duas guerras mundiais. A guerra, naquele momento da pesquisa do mestrado, era, para mim, pano de fundo das recordações de Dick e Robert em suas sessões com Melanie Klein. Ainda não me era possível utilizar a memória aos meus propósitos, me dando conta de que um sofrimento social estava posto, em Freud, em Lacan e em Benjamin.

Assim, a memória não é somente aquela que quer ser preservada - na recordação de dias felizes das fotos preservadas dos entrevistados na enquete -; a fotografia traz uma imagem perdida, uma imagem de que "aquilo existiu" e "não voltará a existir mais". Na escrita de Câmera clara, Barthes mostra o caráter testemunhal da 
fotografia, da captura imagética da perda - tanto quanto em Diário de luto: em ambas experiências busca-se uma mediação.

A memória sofre as consequências da experiência de pesquisar, pois, se antes estava romantizada, costurada pelos belos textos freudianos do Bloco Mágico, Gradiva, Construções em Análise, Lembrança da infância de Leonardo da Vinci, no pós escrito de Freud à análise do Pequeno Hans, o doutorado chegou com força aguda e ácida da noção de real.

Numa exposição em São Paulo intitulada a Arte da lembrança, onde o artista trabalha a fotografia como literatura, o curador da mostra afirmou:

Algo de nós está ali contido na mancha fotográfica: um destino, um desejo, uma perda, uma palavra que pronunciada será incapaz de percorrer o caminho de volta, um suspiro, a garganta das coisas. Sintomas dos quais surgiria, extraído desde sua dormência, tudo o que existiu e não mais existe, o presente e já passado, presente apesar de sua ausência. (Moura, 2015, grifo nosso)

O presente passado, presente apesar da ausência, é uma das formas de representação da perda, mas ao mesmo tempo parece destacar o que não pode ser totalmente recuperado por nenhuma linguagem. Há uma lacuna entre o experimentado e sua representação, e há outra lacuna entre a representação e a sua nova apresentação. A falta ainda permanece, ainda que se tente re-apresentá-la. A fotografia é, ao mesmo tempo, a captura precoce da perda.

Estudamos a noção de experiência (Erfahrung) e percebemos o quanto ela está ligada ao perigo, viagem, transformação e travessia. Na teoria freudiana e lacaniana a experiência está ligada à perda de objeto, à relação do sujeito com o objeto, ao problema dos vínculos múltiplos e descontínuos do sujeito com o mundo. Depois, nos ativemos às experiências sensíveis daqueles que, como num ato de fé, insistem em algo que possa representar o irrepresentável, por meio da escrita. Estes mesmos autores, Barthes e Emerson, surgem como aqueles que fizeram "nascer a teoria daquilo que há de mais profundo da intimidade do emotivo" (Fontanari, 2015, p. 36).

Nas leituras de Freud e Benjamin, do processo histórico e a modernidade, acrescentamos a pesquisa sobre o processo social de subjetivação da perda. O valor que demos às experiências sensíveis nesta tese de doutoramento não foi senão para mostrar que elas são a báscula entre o universal da experiência que entendemos como Perda da 
experiência e a subjetivação do que é dado pelo universal, que chamamos de Experiências de Perda. O grafo a seguir pretende demonstrar esta ideia:

\section{Perda de experiência}

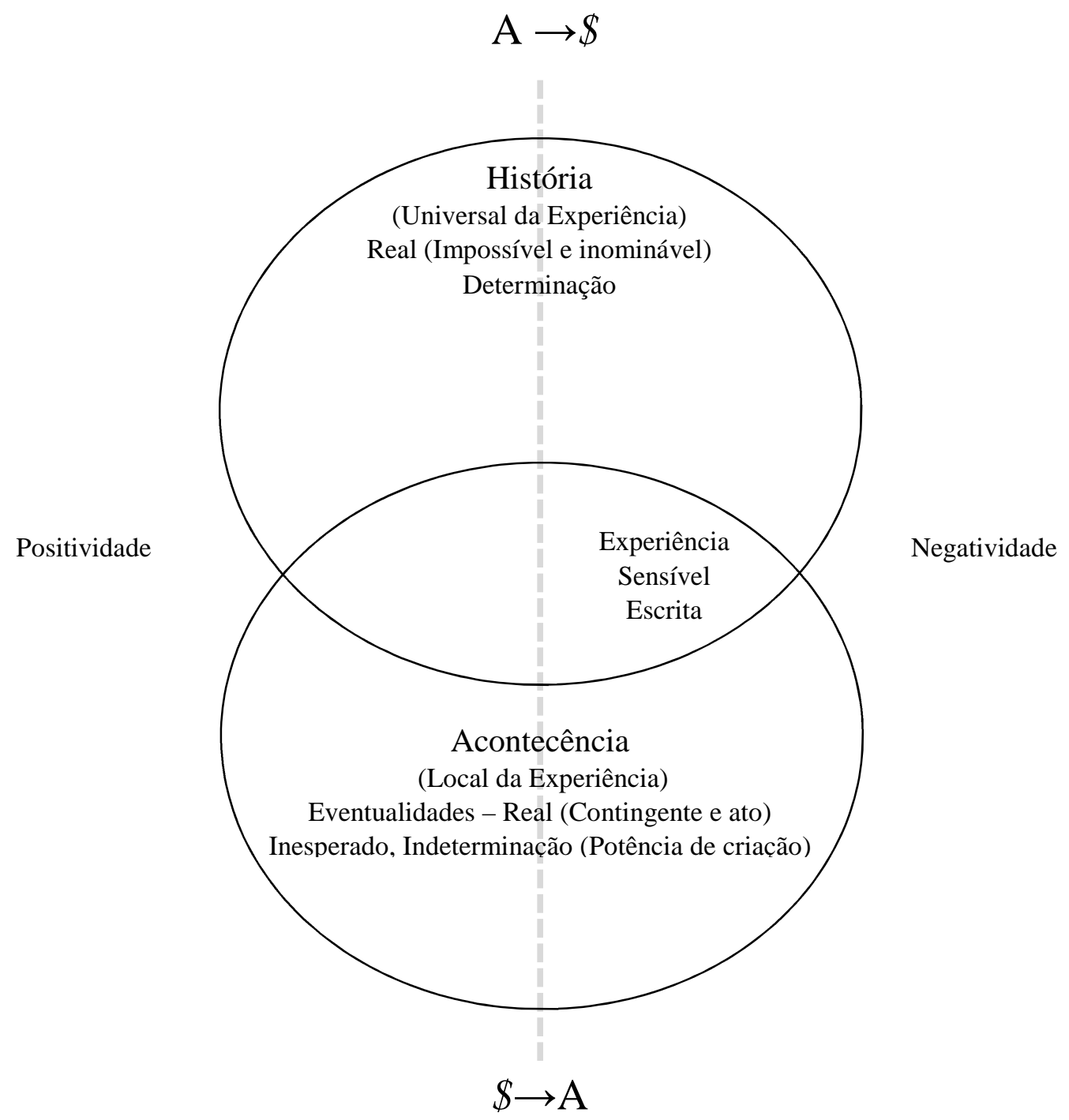

Experiências de perda

Quando Emerson afirma que "o segredo do mundo é o nó entre a pessoa e o evento", pensamos o nó no sentido mesmo de sua amarração, do laço com o outro, a experiência sensível. Essa experiência que se expressa na fragilidade narrativa, na escrita. Poderíamos situar aí o sofrimento do sujeito numa experiência concebida em termos de destino, com toda a angústia que a indeterminação acarreta - mas onde se situa o cerne da liberdade do sujeito. No caso de Pierre Rey, podemos observar como a liberdade operou na mediação com o social, com o "nó": 
Perdido no próprio esgotamento de meu gozo- mas trapaceando comigo mesmo quanto à natureza de meus verdadeiros desejos-, tudo só se destinava a manter ao seu redor a cerca cuja natureza minha aparente indiferença disfarçava: desde que nada o ameaçasse, pouco me importava o resto. Até que fui atingido em cheio pela observação irritada de uma pessoa próxima: -No fundo, com esse ar de belo indiferente, você acaba tratando os inimigos do mesmo modo que os amigos.

A análise acabou com isso: com a extinção de todo o medo, pude por fim sentir a felicidade de ser vulnerável. (Rey, 1989/2006, p. 114)

A análise acabou com o medo sem fazer com que o perigo deixe de existir, o que seria impossível, mas a relação do sujeito com o desconhecido não precisa lhe trazer sofrimento e nem aprisioná-lo dentro de um sintoma: "a ambição clínica da psicanálise envolve tanto retirar sintomas quanto mitigar sofrimento e, principalmente, realizar a cura deste como se realiza uma experiência. Ela não é, porém, apenas restituição da experiência perdida, mas é também a realização dessa perda” (Dunker, 2015, p. 282, grifo nosso). A realização da perda diz respeito a situar uma vida em termos de destino.

Do lado da História haverá sempre uma ação; entretanto, o efeito de real do lado do sujeito dá ao perigo uma característica: não somente o medo de que algo irá acontecer, mas o risco a favor de uma nova possibilidade. Existe uma ação possível do sujeito diante do inesperado, diante do risco. Essa ação se apresenta de duas formas: aceitando a condição do sujeito vinculada ao acaso e à indeterminação e posicionando, deste modo, sua potência de criação diante o inominável. Esse conjunto de experiências contingentes Rey nomeia como vulnerabilidade.

Se do lado da História há um universal da experiência, como a guerra, por exemplo, há um impossível instalado nessa determinação radical. Não há o que fazer diante dessa ação radical do social. Isso nos fez pensar que a estrutura da noção de experiência parece análoga à estrutura do recalque, pois dele sabemos apenas seus resultados. Do quiasmo que escolhemos para o título da tese - Da experiência de perda à perda da experiência — podemos pensar na relação entre a fragilidade narrativa e suas possibilidades de tratá-la, com o mecanismo denominado por Freud de recalque (Verdrängung). O diagnóstico social empreendido por W. Benjamin, denominado perda da experiência, teria como homóloga a operação de recalque no sujeito - pelo fato de que não há sujeito, hoje, que não esteja submetido à crise e sofrimento modernos. Por isso não há como responder de uma forma direta se o sujeito 
moderno está sujeito a mais perdas e lutos do que antes. Tudo o que decorre depois da perda, incluindo a busca infinita de sua tentativa de recuperação, já é a tentativa de tratar a perda radical que a modernidade impõe.

Daí meu olhar para este momento em que se faz necessário escrever algo sobre o final de uma pesquisa; assim, uma pergunta que se formula é: então os momentos difíceis da vida são propícios à criação ou elaboração? Não todos. E para aqueles a quem podemos dizer que sim, estas experiências são as experiências sensíveis e paradoxais pelas quais sua relação ao Outro e se mostra dissimétrica da relação do Outro a si. Nesse lugar Lacan postulava a existência do objeto $a$, causa de desejo e função a-mais de gozar. E se tivesse que resumir numa frase o que concluí da pesquisa, esta frase seria: o modo como o sujeito se aproxima do real define toda sua vida. E, como clínica, penso que a forma de diagnosticar, de escutar o outro, advém dessa forma de verdade em relação ao real; afinal, o que é que queremos dizer quando utilizamos a expressão "experiência de análise"? Fazer trabalhar a potência de criação diante o inesperado, ao mesmo tempo em que a potência de elaboração diante do indiscernível. Mallarmé fez a ligação entre o pensamento, a práxis e a potência da ação quando afirmou: "Todo pensamento emite um lance de dados". (Mallarmé apud Badiou, p. 12)

Depois de várias leituras dos textos, não acho que em nenhum momento Freud negou a realidade, mas - como afirmamos na experiência de Almodóvar — abraçou-a como se abraça a doença de alguém que se ama.

Assim também situo Lacan em meus estudos. A acepção do real na teoria lacaniana, como ele diz, é um limite de nossa experiência; porque o real nos limita, possui suas bordas, mas não impossibilita, na medida em que pode surgir como contingência e acaso — ou, como impossibilidade e limite, vir a ocupar um lugar indeterminado no destino do sujeito. Estas seriam experiências produtivas de indeterminação, que acabam por colocar o ordinário, o corriqueiro, numa ação que pode mudar a vida do sujeito. A experiência da psicanálise faculta a um sujeito deixar de praticar um cara ou coroa com seu destino, para torná-lo um jogo de dados. Retira o sujeito da miséria neurótica do "tudo ou nada", saindo da impotência à impossibilidade — que, com o acaso, ganha novos nomes: "imprevisível, incalculável, inominável, indiscernível". E ainda sim, diante do resultado o sujeito tem a alternativa de se posicionar, na atitude pensada, como Octavia e Lívia, as mães enlutadas de Sêneca. Deste modo o analista atende, escuta a partir de sua acepção de real, para se colocar — 
assim como o paciente - na linhagem do indeterminado e do determinado, no curso de um tratamento. Por isso o limite do real na experiência, pois é o momento em que o sujeito se encontra com a própria verdade. Tanto que o objeto topológico proposto por Lacan para pensar a experiência da psicanálise é a garrafa de Klein: ela comporta uma indeterminação, um caminho indecidido. Assim, do lado do sujeito estará sempre o perigo; mas há uma ação que também está do lado do sujeito, em sua decisão.

Otimistas? O que Freud parece ter feito é uma leitura realista da humanidade. Numa carta a Salomé escreveu: "Não posso ser um otimista e acredito que me distingo dos pessimistas apenas porque as coisas cruéis, estúpidas e sem sentido não me perturbam, pois desde o começo aceitei-as como parte daquilo de que é feito o mundo." (Freud apud Peres, p. 50) Não se pode transformar o real, mas uma decisão após e diante dele deve surgir. 


\section{Referências Bibliográficas}

ABBAGNANO, N. Dicionário de filosofia. São Paulo, Martins Fontes, 1998.

AGAMBEN, G. Infância e história. Buenos Aires, 2007. Adriana Hildalgo Editora.

ADORNO, T. Correspondência Adorno-Benjamin 1928-1940. Trad. José Marques Macedo. São Paulo. Unesp, 2012.

ALLOUCH, J. A psicanálise é um exercício espiritual? Campinas. Editora Unicamp. 2014. Trad. Paulo Sergio de Souza Junior e Maria Rita S. Moraes.

BATAILLE, L. O umbigo do sonho. Rio de Janeiro, 1998.

BADIOU, A. \& ROUDINESCO, É. Lacan Passado Presente. Rio de Janeiro. Editora Bertrand. 2012.

BADIOU, A. Para uma nova teoria do sujeito. Relume Dumará, 1994.

BARTHES, R. Diário de luto. São Paulo. Martins Fontes, 2001. Trad. Leyla Perrone

BECKETT, S. Primeiro amor. (1970) São Paulo, Cosac Naify. 2014

BENJAMIN, W. O Narrador. Considerações sobre a obra de Nikolai Leskov. In Magia e Técnica, Arte e Política. Brasília. Brasiliense, 1996.

BENJAMIN, W. Experiência e pobreza. In: Magia e Técnica, Arte e Política. Brasília. Brasiliense, 1996. Trad. Sérgio Paulo Rouanet.

BEZERRA, Jr. B. "A noção de experiência e sua importância para a clínica atual”. In: Arruda, A.; Bezerra Jr., B.; Tedesco, S. (org.) Rio de Janeiro. Garamond. 2008.

BECKETT, S. Primeiro amor. São Paulo, Cosac Naify, 2014.

BIRMAN, J. Sobre o mal-estar na modernidade In: Estilo e modernidade em psicanálise. São Paulo, Editora 34. 1997

BOSCO, F. E livre seja este infortúnio. Rio de Janeiro. Azougue Editorial, 2010.

CABAS, A. G. A propósito da cura no discurso analítico. In : A eficácia da cura em psicanálise. 45-63. CRV, Curitiba, 2009.

CAMPOS, S. Passema : testemunhos de um final de análise. Belo Horizonte, Scriptum, 2014. 
CHAVES, E. (2014) Prefácio à edição brasileira de A psicanálise é um exercício espiritual? Campinas. Editora Unicamp. 2014. Trad. Paulo Sergio de Souza Junior e Maria Rita S. Moraes.

CHEMAMA, R; VANDERMERSCH, B. Dictionnaire de la psychanalyse. Larousse, 2009.

CHECCHIA, M. Poder e política na clínica psicanalítica. São Paulo. Annablume. 2015

CERTEAU, M. História e psicanálise. Entre ciência e ficção. Trad. Guilherme de Freitas Teixeira. Belo Horizonte, Ed. Autêntica, 2012.

DERRIDA, J. O que é uma tradução relevante? Trad. Olívia Niemeyer Santos. In: Alfa, São Paulo, 44. 13-44. 2000

DELRIEU, Alain. Sigmund Freud. Index Thématique. Paris. Ed. Anthropos. 1997.

DIDIER Weill, A. SAFOUAN. Trabalhando com Lacan: na análise, na supervisão, nos seminários. Tradução Claudia Berliner, Rio de Janeiro, JZE, 2009.

DURAS, M. Cadernos da Guerra e outros textos. Trad. Mario Laranjeira. São Paulo. Editora. Estação Liberdade, 2009.

DUNKER, C.I. L. Estrutura e constituição da clínica psicanalítica. São Paulo. Annablume, 2011.

DUNKER, C.I.L. Lacan e a ética discursiva. São Paulo. Hacker editores, 1996.

DUNKER, C.I.L. Mal-estar, sofrimento e sintoma. São Paulo, 2015. Boitempo Editorial. FARGE, A. Lugares para a História. Trad. Fernando Scheibe. Belo Horizonte. Ed. Autêntica, 2011.

FELMAN, S. Educação e crise ou as vicissitudes do ensino. In: Catástrofe e Representação. Nestrovski, A.; Seligmann- Silva. (org.) São Paulo. Ed. Escuta, 2000.

FIGUEIREDO, L.C.M. “Teorias e práticas na psicologia clínica: um esforço de interpretação". In: Revisitando as psicologias- da epistemologia à ética das práticas e discursos psicológicos. 2 edição revista e ampliada, São Paulo/Petrópolis: EDUC/Vozes, 1996.

FOUCAULT, M. Dits et écrits. 1978. Paris. Gallimard, 2001. 
FREUD, S. 1895. La vivencia de satisfacción. Proyecto de Psicologia. Trad. José Luis Etcheverry. Buenos Aires. Amorrortu Editores, 2004

FREUD, S. 1895. La vivencia de dolor. Trad. José Luis Etcheverry. Buenos Aires. Amorrortu Editores, 2004 (1900) A interpretação dos sonhos. (1900) Porto Alegre, 2012. L\&PM Editores. Trad. Renato Zwick. , (1914) A História do movimento psicanalítico. Trad. José Luis Etcheverry. Buenos Aires. Amorrortu Editores, 2004 , (1917) Luto e melancolia. São Paulo, Cosac Naify. 2011. Tradução Marilene Carone. , (1920) Além do princípio do prazer. , (1930) O Mal-estar na civilização (1930). São Paulo, Cia das Letras. Trad. Paulo César de Souza. , (1937) Fischer. Frankfurt, 1975

FONTANARI, R. A inquietante Câmara Clara. In: Revista Cult. 2014, p. 26

GADAMER, H. G. Verité et méthode. Les Grandes lignes d’une herméneutique philosophique. Paris : Seuil, 1996.

GAGNEBIN, J.M. História e Narração em Walter Benjamin. São Paulo, Perspectiva, 2004.

GINZBURG, J. A interpretação do rastro em Walter Benjamin. In: Walter Benjamin: rastro, aura e história. Sedlmayer, S.; Ginzburg, J. Belo Horizonte. Ed. UFMG, 2012.

GINZBURG, J. A literatura contra o Estado em 1968: política e exclusão em Clarice Lispector. In: Via Atlântica N. 12 Dez/2007

GINZBURG, J. Linguagem e trauma na escrita do testemunho.

GODIN, Jean- Guy Godin. Jacques Lacan, calle de Lille N. 5. Trad. Victor Goldstein. Buenos Aires. Ediciones de La Flor. 1992.

GOLDSCHMIDT, V. Tempo histórico e tempo lógico na interpretação dos sistemas filosóficos. 
HADDAD, G. O dia em que Lacan me adotou. Trad. Procópio Abreu. Rio de Janeiro. Companhia de Freud. 2003

HORNE, B. Fragmentos de uma vida psicanalítica. Da Ipa a Lacan. Rio de Janeiro, 1999.

IANNINI, G. Estilo e verdade em Jacques Lacan. Belo Horizonte. Autêntica Editora, 2013.

JAY. M. Cantos de Experiencia. Variaciones modernas sobre um tema universal. Buenos Aires, Paidós. 2009

JAMES, W. O pragmatismo. In: Os pensadores. São Paulo, Abril, 1979.

KAFKA F. Carta ao pai. 1919. São Paulo. L\&PM. 2014

KEHL, M. Minha vida daria um romance. In: Bartucci, G. (2001), Psicanálise, literatura e estratégias de subjetivação. Rio de Janeiro. Imago.

KEHL, M. O Tempo e o cão. São Paulo. Boitempo, 2009.

KEHL, M. História e Repetição. In: Os paradoxos da repetição. São Paulo, Annablume, 2014

KOLTAI, C. Política e psicanálise. O estrangeiro. São Paulo. Escuta, 2000

KRUTZEN, H. Jacques Lacan. Index référentiel. Paris. Anthropos, 2009.

LARROSA, J. "Literatura, experiência e formação". In: Linguagem e educação depois de Babel. Belo Horizonte. Ed. Autêntica, 2004.

LACAN, J. Staferla.

LACAN, J. Escritos. Rio de Janeiro. JZE. 1998.

LACAN, J. Outros escritos. Rio de Janeiro. JZE, 2003

LEIBSON, L. “A través del Espejo. Notas acerca de la experiência y lo imaginário”. In: El psicoanálisis como experiência. Coloquio em Buenos Aires. Letra Viva. Argentina, 2004, p. 110.

LISPECTOR, C. Carta ao Ministro da Educação. In: A descoberta do mundo. Rio de Janeiro. Ed. Rocco, 1999. 
LEVI, P. É isto um homem? Trad. Luigi Del Re. Rio de Janeiro. Ed. Rocco. 1988.

LEVI, P. O retorno de Lorenzo. In: 71 contos de Primo Levi. Trad. Maurício Santana Dias. São Paulo. Companhia das Letras, 2005.

LOUREIRO, I. R. B. O Carvalho e o pinheiro. Freud e o estilo romântico. São Paulo. Escuta, 2002

LOUREIRO. Psicanálise e filosofia: em busca de uma noção de experiência. São Paulo. 2014. (artigo no prelo)

LOFFREDO, A. M. Insana Modernidade. In: Figuras da sublimação na metapsicologia freudiana. São Paulo. Escuta, 2014.

MEZAN, R. Esquecer? Não: inquecer. In: A sombra de Don Juan e outros ensaios. São Paulo: Perspectiva, 1993, p. 51-62

MILÁN-RAMOS, J. Guillermo. Passar pelo escrito. Campinas, Mercado das Letras, 2007.

NETO, A. N. "A noção de experiência no pensamento de Winnicott como conceito diferencial na história da psicanálise”. In: Natureza Humana, 9 (2): 221 - 242 jul a dez. 2007.

PEREC, G. A cena de um estratagema. Extraído da coletânea Species of space and other pieces, com o título "The Scene of a Stratagem. London: Penguin Books, 1999. Publicado originalmente na revista Cause Commune ( Les lieux d'une ruse ) n.1, p. 7788, 1977. Traduzido por Ana Cecília Carvalho e Fabio Belo. In: Psyquê. Ano IX, No. 15, jan-jun 2005.p.13-21.

PEREC, G. A vida modo de usar. Trad. Ivo Barroso. São Paulo, Cia das letras, 2009.

PERES, U. T. Uma ferida a sangrar-lhe a alma. In: Luto e Mealncolia. Freud. São Paulo, Cosac Naify, 2011.

REGNAULT, F. Lacan and experience. In: Lacan and the human sciences. University of Nebraska, 1991.

REIS, M.G.P. De uma escrita com função de testemunho: Abordagem psicanalítica da transmissão da experiência. Dissertação de mestrado. Porto Alegre. 2010.

REY, P. Uma temporada com Lacan. Rio de Janeiro. Companhia de Freud. 2010. 
ROCHA, Z. A Experiência psicanalítica: seus desafios e vicissitudes, hoje e amanhã. Ágora, Rio de Janeiro.Vol. XI. N. 1 Jan/Jun 2008 101- 116

ROTSEIN, Eduardo. Inconsciente e experiência analítica. Dissertação de Mestrado. Universidade Federal do Rio de Janeiro. 2010.

SAFATLE, V. A paixão do negativo. Lacan e a dialética. São Paulo. Ed. Unesp. 2006

SELIGMAN-SILVA, M. O local da diferença. São Paulo, Ed. 34, 2005.

SHUSTERMAN, R. Vivendo a arte. O pensamento pragmatista e a estética popular. São Paulo, editora 34, 1998.

WILLEMART, P. Psicanálise e teoria literária. São Paulo, Perspectiva, 2014. 